\title{
A ROLE FOR GLYCOGEN SYNTHASE KINASE 3 BETA IN THE REGULATION OF GLUCAGON GENE TRANSCRIPTION BY INSULIN
}

\author{
Dissertation \\ zur Erlangung des Doktorgrades \\ der Mathematisch-Naturwissenschaftlichen Fakultäten \\ der Georg-August-Universität zu Göttingen
}

vorgelegt von

Nikolaos Dimopoulos

aus Athen, Griechenland 
Diese Arbeit wurde in der Abteilung Molekulare Pharmakologie am Zentrum Pharmakologie und Toxikologie der Georg-August-Universität Göttingen angefertigt.

Die Untersuchungen wurden durch Mittel des Graduiertenkollegs 335 unterstützt.

D 7

Referent : $\quad$ Prof. Dr. R. Hardeland

Korreferent : $\quad$ Prof. Dr. T. Pieler

Tag der mündlichen Prüfung : 


\section{CONTENTS}

\section{CONTENTS}

FIGURES and TABLES

ABBREVIATIONS

\section{INTRODUCTION}

1. 1 Glucagon and diabetes mellitus

1.2 The insulin signalling pathways 2

1. 2. 1 The PI(3)K pathway 2

1. 2. 2 The MAP kinase pathway 3

1. 2. 3 Phosphatases in insulin signalling 4

1. 3 Glucagon and pancreatic islets 4

1. 4 The glucagon promoter 5

1. 4. 1 Regulation by insulin 5

1. 4. 2 Cis-control elements on the glucagon promoter 6

1. 5 Glycogen synthase kinase 3 (GSK3) 8

1. 5. 1 Characteristic features of GSK3 8

1. 5. 2 Structure of GSK3 and regulation of its enzymatic activity 8

1. 5. 3 GSK3 consensus site for phosphorylation 9

1. 5. 4 PKB mediated inhibition of GSK3 10

1. 6 GSK3 substrates $\quad 10$

1. 7 The Wnt pathway 12

1. 8 GSK3 inhibitors 13

1.9 Aim of the study 14

2. MATERIALS and METHODS

2.1 MATERIALS 15

2. 1. 1 Instruments 15

2.1.2 Consumables 16

2. 1.3 Antibiotics 16

2. 1. 4 GSK3 inhibitors 17

2. 1.5 General Chemicals 17

2. 1. 6 Kits 19

2.1.7 Bacterial culture materials $\quad 19$

2. 1. 8 Eukaryotic cell line $\quad 19$

2. 1.9 Eukaryotic cell culture materials $\quad 19$

2. 1. 10 General buffers and media $\quad 20$ 
2. 1. 11 Reporter gene plasmids and expression plasmids 21

2.1.12 Antibodies, proteins, peptides, molecular weight 22 standards and enzymes

2. 2 METHODS 23

2. 2. 1 Standard methods of molecular cloning 23

2. 2. 1. 1 Preparation of competent Escherichia coli bacteria 23

2. 2. 1. 2 Transformation of competent bacteria 23

2. 2. 1. 3 Mini preparation of plasmid DNA 23

2. 2. 1. 4 Maxi preparation of plasmid DNA 24

2. 2. 1.5 Measurement of DNA concentration 25

2. 2. 1. 6 Restriction enzyme analysis of DNA 25

2. 2. 1. 7 Agarose gel electrophoresis 25

2. 2. 1.8 Purification of DNA from agarose gel 26

2. 2. 1.9 Blunt-end cloning 26

2. 2. 1.10 Dephosphorylation of 5' protruding DNA ends 27

2. 2. 1. 11 Ligation $\quad 27$

2. 2. 1. 12 DNA Sequencing 27

$\begin{array}{ll}\text { Sequencing reaction } & 27\end{array}$

Sequencing polyacrylamide gel electrophoresis 28

2. 2. 2 GST-recombinant protein expression and purification in bacteria 29

2. 2. 3 Affinity purification of GSK3 from InR1G9 cells 30

2. 2. 4 SDS-polyacrylamide gel electrophoresis 31

2. 2. 5 Western Blot Analysis 33

2. 2. 6 Phosphorylation of GST-fusion proteins by recombinant GSK3 $\beta$ in vitro 35

2. 2. 7 GSK3 activity measured by ex vivo assay 36

$\begin{array}{ll}\text { 2. 2. } 8 \text { Eukaryotic cell culture methods } & 37\end{array}$

2. 2. 8. 1 Cell culture $\quad 37$

2. 2. 8. 2 DEAE-Dextran transfection $\quad 37$

2. 2. 8.3 Insulin or GSK3 inhibitors treatment 38

2. 2. 8.4 Cell extract preparation 38

2. 2. 8.5 Luciferase reporter gene assay 39

2. 2. 8. 6 GFP reporter gene assay 40

2. 2.9 Immunocytofluorescence $\quad \mathbf{4 0}$

2. 2. 10 Nuclear Extracts from Tissue Culture Cells 41

2. 2. 11 Two-dimensional gel electrophoresis 42

2. 2. 12 MTT test 42

2. 2. 13 Software $\quad 43$

3. RESULTS

3. 1 Effect of GSK3 $\beta$ overexpression on glucagon gene transcription 44

3. 2 Expression and regulation by insulin of endogenous GSK3 45 activity in InR1G9 cells 
3. 2. 1 Expression of GSK3 in InR1G9 cells 45

3. 2. 2 Regulation of GSK3 enzymatic activity by insulin in InR1G9 cells 46

3. 3 GSK3 inhibitors and their effect on glucagon gene transcription 48

3. 3. 1 Effect of various GSK3 inhibitors on glucagon gene transcription 48

3. 3. 2 Effect of SB-216763 on glucagon gene transcription in a dose 48 dependent manner

3. 3. 3 Effect of GSK3 inhibitors on the transcriptional activity 50 of a CMV promoter

3. 3. 4 The GSK3 inhibitors were tested for potential cytotoxic effects 51 via the MTT test

3. 3. 5 GSK3 inhibitors abolished the effect of GSK3 $\beta$ wt overexpression 52 on glucagon gene transcription

3. 3. 6 Inhibition of GSK3 activity in InR $1 G 9$ cells as revealed by ex vivo assay 53

3. 3. 7 GSK3 inhibitors stabilized $\beta$-catenin protein levels 54

3. 4 Deletion and internal mutation analysis of the glucagon $\quad 57$ promoter after treatment of InR1G9 cells with the GSK3 inhibitor, SB-216763

3. 4. 1 Effect of SB-216763 on the transcriptional activity of 5'-deleted fragments of the glucagon promoter

3. 4. 2 Effect of SB-216763 on the transcriptional activity of 3'-deleted fragments of the glucagon promoter

3. 4. 3 Effect of SB-216763 on a glucagon reporter gene that the Pax6 binding sites have been mutated

3. 5 Effect of SB-216763 on Pax6 mediated transcriptional activity

3. 6 Effect of SB-216763 on CBP mediated transcriptional activity 60

3. 7 Effect of GSK3 $\beta w t$ overexpression on the activity of Gal4-CBP 64

3. 7. 1 Effect of GSK3 $\beta$ wt overexpression on Gal4-CBP activity in the 64 context of the glucagon promoter

3. 7. 2 Effect of GSK3 $\beta$ wt overexpression on the transcriptional activity 64 conferred by $N$-terminal and $C$-terminal part of $C B P$

3. 7. 3 Mapping the effect of GSK3 $\beta$ wt overexpression within the 64 carboxy-terminal part of $C B P$

3. 8 GSK3 $\beta$ mediated phosphorylation of Pax6 and CBP as revealed by 68 in vitro assay

3. 8. 1 Phosphorylation of Pax6 transactivation domain (TAD) by GSK3 68 in vitro

3. 8. 2 Phosphorylation of a C-terminal part of CBP consisting of amino 68 acids 2040-2305 by GSK3 $\beta$ in vitro

3. 9 Two-dimensional gel electrophoresis of nuclear proteins from InR1G9 cells 
4. DISCUSSION

4. 1 GSK3 expression in InR1G9 cells and inhibition of enzymatic activity by insulin-triggered phosphorylation

4. 2 Regulation of glucagon gene transcription by GSK3 $\beta \quad 73$

4. 3 GSK3 responsive element in the glucagon promoter $\quad 75$

4. 4 GSK3 regulates transcriptional activity and phosphorylation $\quad 76$ of Pax6 in vitro

4. 5 GSK3 regulates transcriptional activity and phosphorylation of CBP in vitro

$\begin{array}{ll}\text { 4. } 6 \text { Final concept } & 78\end{array}$

4. 7 Perspectives $\quad 80$

4. 7. 1 GSK3 inhibitors as novel antidiabetic drugs?

4. 7. 2 Studying insulin resistance in InR $1 G 9$ cells 80

$\begin{array}{ll}\text { REFERENCES } & 81\end{array}$ 


\section{FIGURES and TABLES}

Fig. 1. Insulin signal transduction pathways 3

Fig. 2. Pancreatic islets 5

Fig. 3. Control cis-elements on glucagon promoter and their corresponding $\quad 7$ transcription factors

Fig. 4. GSK3 isoforms 9

Fig. 5. Mechanism of activation of GSK3 10

Fig. 6. Molecular mechanism by which phosphorylation inhibits GSK3 activity 11

Fig. 7. GSK3 pools within the cell 13

Fig. 8. GSK3 $\beta$ constructs under the control of the CMV promoter 44

Fig. 9. Effect of GSK3 $\beta$ overexpression on glucagon gene transcription 45

Fig. 10. Expression of GSK3 in InR1G9 cells and regulation of its enzymatic 47 activity by insulin

Fig. 11. Effect of various GSK3 inhibitors on glucagon gene transcription 49

Fig. 12. Concentration response curve of the GSK3 inhibitor, SB-216763, 50 on glucagon gene transcription

Fig. 13. Effect of GSK3 inhibitors on CMV promoter activity 51

Fig. 14. GSK3 inhibitors were tested for potential cytotoxic effects via the 52 MTT test

Fig. 15. Effect of GSK3 inhibitors on the stimulation of glucagon gene transcription by GSK3 $\beta w t$ overexpression

Fig. 16. SB-216763 inhibits GSK3 activity in InR1G9 cells 54

Fig. 17. GSK3 inhibitors induced accumulation of $\beta$-catenin in cytosol as 55 revealed by immunofluorescence

Fig. 18. GSK3 inhibitors induced stabilization of $\beta$-catenin as revealed 56 by western blot

Fig. 19. Effect of SB-216763 on the transcriptional activity of 5'-deleted fragments of the glucagon promoter

Fig. 20. Effect of SB-216763 on the transcriptional activity of 3'-deleted fragments of the glucagon promoter

Fig. 21. Effect of SB-216763 on a glucagon reporter gene that the Pax6 binding sites have been mutated

Fig. 22. Inhibition by SB-216763 of Gal4-Pax6 transcriptional activity 
Fig. 23 Inhibition by SB-216763 of Gal4-CBP transcriptional activity 63

Fig. 24. Effect of GSK3 $\beta$ wt overexpression on Gal4-CBP activity in the 65 context of the glucagon promoter

Fig. 25. Effect of GSK3 $\beta w t$ overexpression on the transcriptional activity conferred by $\mathrm{N}$-terminal and C-terminal part of CBP

Fig. 26. Mapping the effect of GSK3 $\beta w t$ overexpression within the carboxy-terminal part of CBP

Fig. 27. Phosphorylation of Pax6 and CBP by GSK3 $\beta$ as revealed by in vitro assay

Fig. 28. Two dimensional gel electrophoresis of InR1G9 nuclear proteins 70

Fig. 29. Insulin inhibits glucagon gene transcription via the $P I(3) K / P K B / G S K 3$ pathway with Pax6 and CBP being critical components in this regulation

Table 1 - Putative GSK3 substrates

Table 2 - GSK3 inhibitors

Table 3 - Chemical structure of the various GSK3 inhibitors 


\section{ABBREVIATIONS}

aa

Ac

Amp

APS

ATP

bp

BSA

${ }^{\circ} \mathrm{C}$

ca.

cAMP

CBP

CDK

cDNA

$\mathrm{Ci}$

CMV

Cpm

CRE

CREB

$\mathrm{CsCl}$

DAPI

DEAE

DMSO

DNA

dNTP

DTT

E.coli

eg

EDTA

ERK

FCS

fig.

FKHR

$\mathrm{g}$

GCG

GFP

GSK3

GST

$\mathrm{h}$

IPTG amino acids

acetate

ampicillin

ammonium persulfate

adenosine triphosphate

base pair

bovine serum albumin

celsius grade

circa

cyclic adenosine-3',5'-monophosphate

CREB binding protein

cyclin dependent kinase

copy deoxyribonucleic acid

curie

cytomegalovirus

counts per minute

cAMP-response-element

cAMP-response-element binding protein

cesium chloride

4',6'-diamidino-2-phenylindole hydrochloride

diethylaminoethyl

dimethylsulfoxide

deoxyribonucleic acid

dideoxy-ribonucleoside-trisphosphate

dithiothreitol

Escherichia coli

for example

ethylendiamine-tetra-acetic acid

extra-signal regulated kinase

fetal calf serum

figure

forkhead-related

gram

genetics computer groups

green fluorescent protein

glycogen synthase kinase 3

glutathione S-transferase

hour or hours

isopropyl-thio-galactoside 
IRE

IRS

$\mathrm{kb}$

$\mathrm{kDa}$

L

LB

LiAc

$\mathrm{LiCl}$

$\mathrm{M}$

$\mathrm{mA}$

MAPK

$\min$

MOPS

mRNA

MTT

NFAT

OD

ON

PAGE

PBS

PCR

PDK

PEG

PEPCK

$\mathrm{PH}$

PI

PI(3)K

PISCES

PKB

PMSF

RNA

RNAi

RNase

Rpm

RT

SDS

sec

SEM

TAD

TAE

TBE

TBS insulin-responsive element

insulin receptor substrate

kilobases

kilodalton

liter

laura bertani

lithium acetate

lithium chloride

molecular weight

milliampere

mitogen activated protein kinase

minute or minutes

3-(N-morpholino)-propansulfonic acid messenger ribonucleic acid

3-(4,5-dimethylthiazole-2-yl)-2,5-diphenyl

tetrazolium bromide

nuclear factor of activated T-cells

optical density

overnight

polyacrylamide gel electrophoresis

phosphate-buffered saline

polymerase chain reaction

phosphatidylinositol dependent kinase

polyethylenglycol

phosphoenolpyruvate carboxykinase

pleckstrin homology

phosphatidylinositol

phosphatidylinositol-3-OH-kinase

pancreatic islet cell-specific enhancer sequence

protein kinase $B$

phenylmethyl-sulfonylfluoride

ribonucleic acid

RNA interference

ribonuclease

rotations per minute

room temperature

sodium-dodecyl-sulfate

seconds

standard error of the mean

transactivation domain

tris-acetate-EDTA

tris-borate-EDTA

tris-buffered saline 
TCA

TE

TEMED

Tris

Tween-20

U

UV

V

Vol

$\mathrm{V} / \mathrm{V}$

$\mathrm{W}$

$\mathrm{W} / \mathrm{V}$ trichloroacetic acid

tris-EDTA

N', N', N', N'-tetramethyldiamine

tris-(hydroxymethyl)-aminomethane

polyoxyethylen-sorbit-monolaurate

unit (enzymatic activity)

ultraviolet

volts

volume

volume per volume

watt

weight per volume 


\section{SUMMARY}

Insulin binding to its receptor on the $\alpha$-cells in endocrine pancreas initiates a signalling cascade that results in inhibition of glucagon gene transcription. Evidence suggests that the $\mathrm{PI}(3) \mathrm{K} / \mathrm{PKB}$ pathway might confer insulin-mediated inhibition, but the mechanism is still not completely understood. The present study characterized the role of GSK3 $\beta$, a well known substrate of $\mathrm{PKB}$, in the regulation of glucagon gene transcription.

GSK3 $\beta$ overexpression by transient transfection in a glucagon producing islet cell line resulted in significant enhancement of glucagon gene transcription. The effect was due to its kinase activity, because a GSK3 $\beta$ kinase-dead mutant had no effect on transcription. Next, endogenous pools of GSK3 were assessed by using various recently developed selective GSK3 inhibitors. All of them inhibited transcription, thereby mimicking the effect of insulin. They could also abolish the effect of GSK3 $\beta$ overexpression on the stimulation of glucagon gene transcription. To validate the mode of action of the inhibitors, we could show that they modulated putative GSK3 substrates in vivo, e.g. they induced stabilization and accumulation of $\beta$-catenin levels.

GSK3 might act through Pax6 and its potential coactivator CBP to regulate glucagon gene expression. Deletion and internal mutation analysis of the glucagon promoter indicated that Pax6 might play an important role to confer inhibition by the GSK3 inhibitor, SB-216763. Transcriptional activity of Pax6 and CBP was inhibited in response to SB-216763 within the glucagon promoter context, as revealed by employing the Gal4 system. Fusing full length $\mathrm{CBP}$, as well as $\mathrm{N}$ - and C-terminal parts of CBP, with the Gal4 domain conferred transcriptional activity as well as responsiveness to GSK3 $\beta$ overexpression. The effect of GSK3 $\beta$ overexpression on the activity of the C-terminal part of CBP was further mapped.

Finally, based on the above findings an in vitro kinase assay was performed. Recombinant GSK3 $\beta$ phosphorylated, even in the absence of priming phosphorylation by another kinase, the transactivation domain of Pax6 and a fragment of CBP consisting of amino acids 20402305 when fused to GST. However, the significance of this phosphorylation in vivo and in the context of the glucagon promoter remains to be shown.

Taken together the results of the present study suggest the involvement of GSK3 $\beta$ in the regulation of glucagon gene transcription by insulin. Through inhibition of GSK3, insulin might repress gene transcription by disruption of a glucagon promoter-specific protein complex, whose critical components seem to be Pax6 and its coactivator CBP. Since hyperglucagonaemia is associated with type 2 diabetes mellitus, understanding the molecular mechanism of insulin-mediated inhibition of glucagon gene expression can prove a valuable tool to develop drugs to treat some of the aspects of the disease. 


\section{INTRODUCTION}

Glucose homeostasis depends upon the balance between hepatic glucose production and glucose utilization by liver, muscle and adipose tissue. This balance is tightly regulated under the control of the main pancreatic hormones insulin and glucagon. After secretion into the portal circulation, glucagon acts predominantly on the liver to enhance hepatic fuel production through glycogenolysis, gluconeogenesis and ketogenesis (Lefebvre, 1995, Knepel, 2001, Jiang and Zhang, 2003). Thus, by stimulating glucose output from the liver, glucagon secures an adequate energy supply for the body's organs. In contrast, an increase in plasma glucose levels results in secretion of insulin from $\beta$-cells of the pancreatic islets of Langerhans. The increase in circulating insulin levels stimulates glucose uptake and glycogen synthesis in peripheral tissues and inhibits hepatic gluconeogenesis (Saltiel, 1996). Therefore, insulin functions as a counterregulatory hormone, antagonizing the biological actions of glucagon. In addition to its primary effects on glucose homeostasis, insulin promotes a wide range of cellular events including lipid metabolism, protein and DNA synthesis and inhibits apoptosis (Kellerer et al., 1999).

Insulin can also regulate the transcriptional rate of a large number of genes either in a positive or in a negative manner (O'Brien and Granner, 1996). Among those that are inhibited by insulin is the glucagon gene. Upon secretion, insulin binds to its receptors on the adjacent $\alpha$ cells in endocrine pancreas and inhibits glucagon gene transcription and secretion as well (Philippe, 1989, Grzeskowiak et al., 2000). Abnormal regulation of glucagon gene expression leads to hyperglucagonaemia contributing to impaired glucose tolerance in diabetes mellitus.

\section{1 Glucagon and diabetes mellitus}

Changes in human lifestyle over the last century have resulted in a dramatic increase in the incidence of diabetes, becoming one of the most prevalent disease affecting over 150 million worldwide (Harris et al., 1998). There are two main forms of diabetes.

Type 1 diabetes is due to auto-immune mediated destruction of $\beta$-cells, resulting in absolute deficiency of insulin. Patients with type 1 diabetes must take exogenous insulin for survival to prevent the development of ketoacidosis (Bell et al., 2001).

Type 2 diabetes, which accounts for over $90 \%$ of cases globally, is characterized by insulin resistance and/or abnormal insulin secretion (Saltiel, 2001a). Insulin resistance refers to the systematic failure of target tissues to respond to circulating concentrations of insulin The epidemic of type 2 diabetes is one of the main causes of morbidity and mortality worldwide. In conjuction with genetic susceptibility it is also associated to environmental and behavioural factors such as sedentary lifestyle and nutrition rich in lipids and carbohydrates (Saltiel et al., 2001b). Type 2 diabetes is also linked to other common health problems such as obesity, hyperlipidaemia, hypertension and atherosclerosis. Therefore, it seems to be a manifestation of a much broader disorder, the so called "metabolic syndrome" (Zimmet et al., 2001). Apart from insulin deficiency and insulin resistance diabetes mellitus is characterized by high 
glucagon levels contributing to hyperglycaemia (Lefebvre et al., 1995). Hence, understanding the molecular mechanism, through which insulin inhibits glucagon gene transcription might present a target for medical intervention in treating patients who suffer from diabetes. Identifying components of the insulin signalling pathway that regulates glucagon gene expression will also enable to reveal the pathophysiology of insulin resistance.

\section{2 The insulin signalling pathways}

\section{2. 1 The PI(3)K pathway}

Over the last years significant progress has been made in elucidating the initial steps of insulin signalling (Leevers et al.,1999, Cheatham et al., 1995). Insulin upon binding to its cell surface receptor exerts its pleiotropic effects. The insulin receptor is a heterotetrameric protein, with two extracellularly localized $\alpha$-subunits and two transmembraneous $\beta$-subunits, which are linked by disulfide bonds (Kellerer et al., 1999). Insulin binding to the $\alpha$-subunit causes conformational changes and thereby activation of the intrinsic tyrosine kinase activity of the $\beta$-subunit, allowing it to phosphorylate itself at several sites within the catalytic domain, and therefore further enhancing the catalytic activity, and the adjacent juxtamembrane domain (Fig.1). Phosphotyrosine residues of the insulin receptor interact with the phosphotyrosinebinding domain of the insulin receptor substrate proteins e.g. IRS-1, recruiting them to the plasma membrane, where they undergo phosphorylation at multiple tyrosine residues (pTyr) by the insulin receptor (Saltiel et al., 2001a). These pTyr residues serve as docking sites for many signalling molecules recruiting them to the plasma membrane as well e.g. they interact with the Src-homology ( $\mathrm{SH} 2$ ) domain of the regulatory p85 subunit of the enzyme termed phosphatidylinositol-3-kinase (PI(3)K) (Roymans et al., 2001, Cantley, 2002). PI(3)K is a heterodimeric enzyme containing, in addition to the regulatory subunit, a catalytic subunit with a phospholipid and a serine kinase activity. Recruiting $\mathrm{PI}(3) \mathrm{K}$ to the plasma membrane enables the p110 catalytic subunit to phosphorylate inositol lipids at the 3 ' position of the inositol ring and thereby catalysing the formation of phosphatidylinositol-3, 4, 5-trisphosphate (PIP3) from phosphatidylinositol-4, 5-bisphosphate (PIP2) (Vanhaesebroeck et al., 1997).

The generation of PIP3 provides an adaptor site for the pleckstrin homology (PH) domain of protein kinase B (PKB/Akt) (Alessi et al., 1998) and 3-phosphoinositide-dependent kinase 1 (PDK1) (Cohen et al., 1997, Toker et al., 2000), colocalizing them at the membrane and allowing PKB to be phosphorylated by PDK1 at Thr308 and subsequently at Ser473 by another kinase termed PDK2 and thus activated (Downward, 1998). PKB seems to play a critical role in many of the cellular effects triggered by insulin. These include stimulation of glucose uptake (trafficking of GLUT4 vesicles to plasma membrane in parallel to the Cbl pathway), glycolysis (phosphorylating phosphofructokinase-2, PFK2), glycogen and protein synthesis (phosphorylating and inhibiting glycogen synthase kinase-3, GSK3, resulting in dephosphorylation and activation of GSK3 substrates including glycogen synthase and eukaryotic initiation factor 2B) (Cross et al., 1995, Boudewijn et al., 1995, Lawlor et al., 2001). Another target for PKB is the ribosomal protein S6 kinase (p70S6 kinase), which is also implicated in the regulation of protein synthesis. Recent reports reveal that PKB is involved in protecting cells from apoptosis by promoting cell survival through 
phosphorylation of the proapoptotic Bcl-2 family member, BAD (Datta et al., 1999). PKB is also capable of phosphorylating and regulating the activity of transcription factors such as members of the forkhead family e.g. FKHR (Brunet et al., 1999).

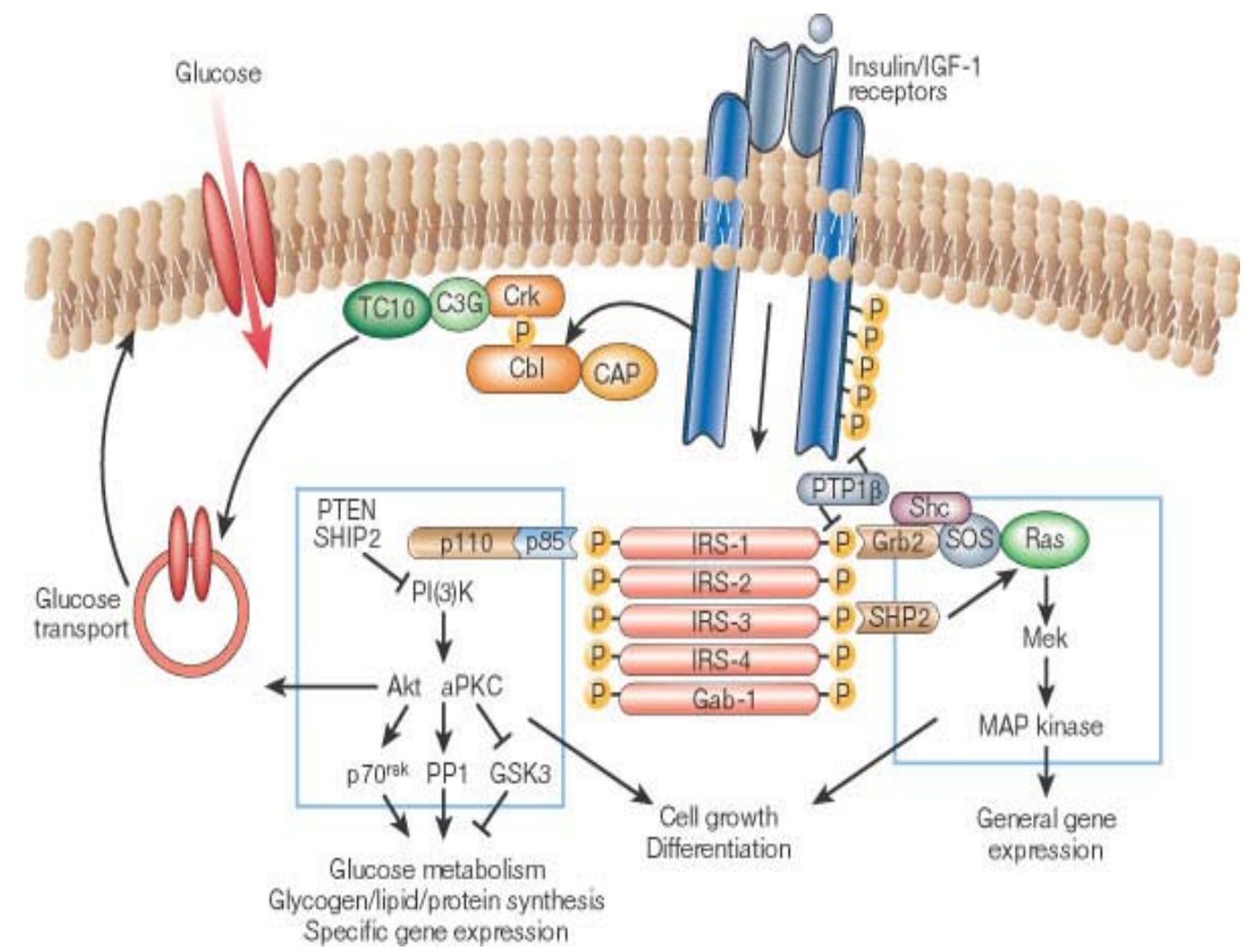

Nature (2001) ; 414: 799-806

Fig. 1. Insulin signal transduction pathways

Insulin upon binding to its receptor activates the tyrosine kinase activity of insulin receptor which phosphorylates and activates members of the IRS family, Shc and Cbl. These molecules interact with other proteins resulting in a diverse series of signalling pathways (such as the PI3K and MAP kinase cascade), which regulate in a coordinate fashion vesicle trafficking, protein and glycogen synthesis, enzyme activation and gene expression.

\section{2. 2 The MAP kinase pathway}

Insulin's action regarding regulation of gene transcription and DNA synthesis has initially been attributed to the classical ras/MAPK kinase pathway (Cheatham and Kahn, 1995). In this pathway, growth factor receptor bound protein 2 (Grb2) links IRS to the guanine nucleotide exchange factor Sos, which activates p21ras. Raf-1 kinase is activated by a mechanism, which still remains unknown, through interaction with p21ras and a cascade of subsequent phosphorylation events is initiated that involves activation of mitogen activated protein kinases (MEK and ERK1/2) (Kyriakis, 1992). The latter is capable of regulating the activity of various transcription factors and thus controlling gene expression. 


\section{2. 3 Phosphatases in insulin signalling}

Several protein phosphatases have been involved in insulin signalling. Among those, an important role seem to play the tyrosine phosphatase PTP1B (Seely et al., 1996) and SHP1/2 (Kuhne et al., 1994). By dephosphorylating the insulin receptor and the insulin receptor substrate respectively they modulate therefore insulin signalling. In addition, the tumour suppressor gene PTEN encodes a lipid phosphatase that removes the phosphate from the 3' position of the inositol ring from PIP3, regulating signals that are mediated through phospholipids (Maehama et al., 1998). SHIP2, a member of the inositol polyphosphate 5phosphatase family, seems to play a crucial role in insulin signalling since loss of this enzyme leads to increased sensitivity of insulin (Clement et al., 2001).

\section{3 Glucagon and pancreatic islets}

The glucagon gene is a single copy gene that is expressed in a highly tissue-restricted manner (Habener et al., 1991). It is mainly expressed in $\alpha$-cells of endocrine pancreas (Unger et al., 1981), in intestinal L-cells (Stümpel et al., 1998), and at low levels in a few neurons in the brain and thymus (Drucker, 1998). A single common transcript using all six exons gives rise to proglucagon prohormone, which is further processed differentially according to various cell types. Therefore, tissue-specific posttranslational modifications result predominantly in the formation of glucagon and to a lesser extent to glucagon-like peptide 1 (GLP-1) in $\alpha$-cells in pancreas. Intestinal L-cells process glucagon to GLP-1, GLP-2 and oxyntomodulin which are associated in the regulation of insulin secretion, intestinal epithelial proliferation and glucose absorption in the intestine, respectively. GLP-1 formed in the brain has been associated with the general control of feeding and the action of leptin.

Glucagon is essential for life since $75 \%$ of basal glucose production from the liver, under resting conditions, is glucagon-mediated. It is responsible for providing organs with fuel, which makes it particularly important for the brain, since glucose is its sole source of energy. Although hyperglycaemia inhibits glucagon secretion, it is not yet clear whether secretion is directly regulated by blood glucose levels (Chen et al., 1989, Dumonteil et al., 1998). It rather seems that the $\beta$-cells of pancreas are the glucose sensitizers that upon elevated plasma glucose secrete insulin, which in a paracrine manner inhibits glucagon gene transcription and secretion. When levels of glucose decrease, insulin is not secreted and cannot regulate glucagon levels any more. However, this hypothesis does not necessarily exclude the possibility that also the $\alpha$-cells can directly respond to fluctuating levels of glucose.

The pancreatic islets of Langerhans constitute a highly specialised structure (Fig.2). Insulinsecreting $\beta$-cells form the core of the islets at about $60 \%$ of the total islet mass, whereas $\alpha$ cells are located at the periphery and consist $25 \%$. In addition, there are also somatostatin producing $\delta$-cells and pancreatic peptide producing cells, which are dispersed along the islets and form only $10 \%$ (Slack, 1995). This organized structure seems apparently to be crucial for the proper coordination of hormone secretion and function of pancreas e.g. $\beta$-cells located in the centre produce and secrete insulin, which directly acts on neighbouring $\alpha$-cells through binding to its receptor. 


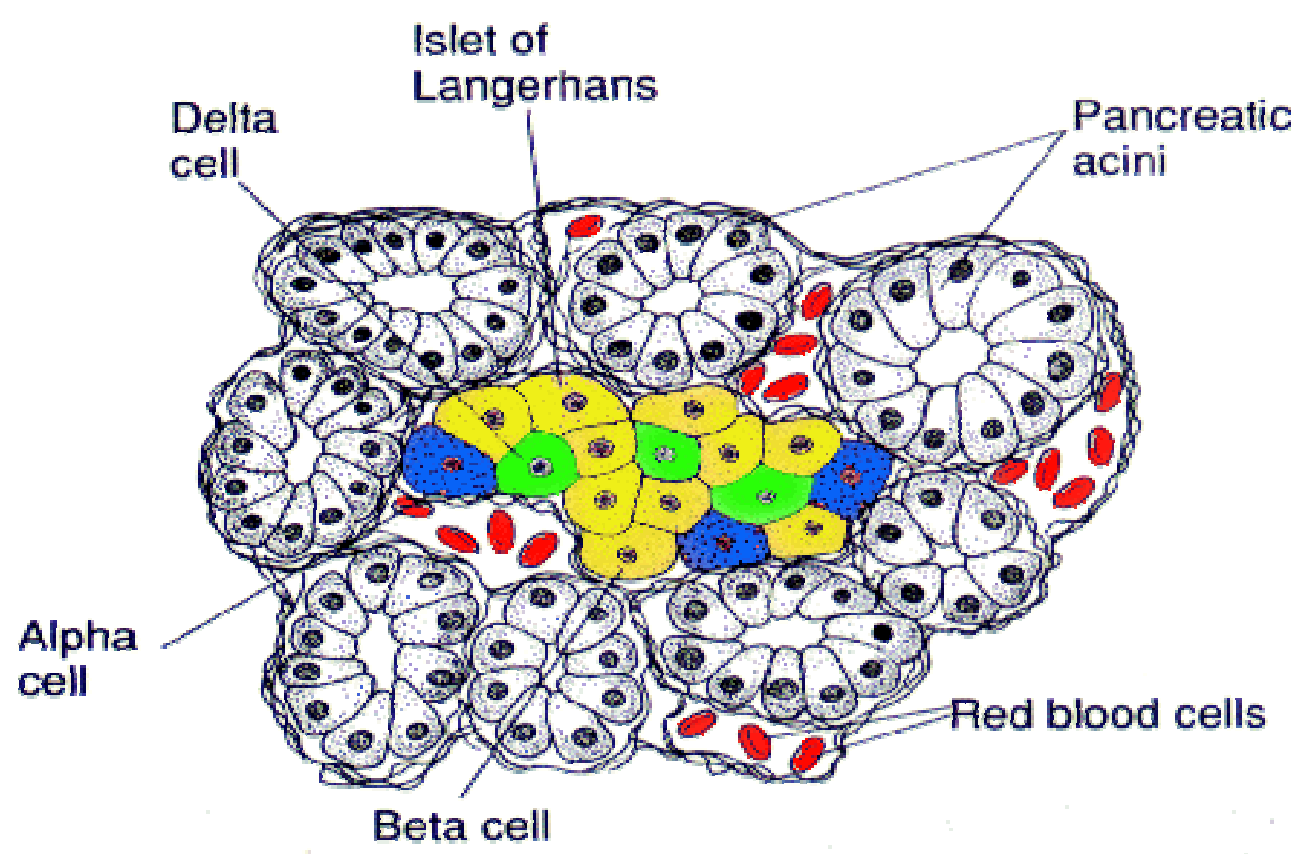

Fig. 2. Pancreatic islets

The endocrine pancreas is constituted of distinct cell types : the $\alpha$ cells (blue) in the periphery which produce glucagon, the $\beta$ cells (yellow) located in the centre which produce insulin and the $\delta$ cells (green) that produce somatostatin.

\section{4 The glucagon promoter}

\section{4.1 Regulation by insulin}

Experiments using transgenic mice (Efrat et al., 1988, Lee et al., 1992), cell-free in vitro transcription systems (Knepel, 1993) and tumor cell lines (Drucker et al., 1987, Philippe et al., 1988) suggest that pancreatic $\alpha$-cell specific activation of glucagon gene is regulated through the 5'-flanking region. A reporter fusion gene containing 350 base pairs of the glucagon promoter is sufficient to drive expression of glucagon gene in glucagon-producing islet tumor cell lines (Philippe et al., 1988) and to confer insulin responsiveness (Philippe, 1989). Initially, it has been suggested that the effects of insulin are mediated through a common transcription factor that binds to an insulin-responsive element (IRE) (AlexanderBridges et al., 1992). IREs have been characterized in a number of genes, but it became apparent that unlike cAMP, which regulates transcription through a single CRE element (Meyer and Habener, 1993), in the case of insulin a single consensus IRE does not exist (O' Brien and Granner, 1996, Chapman et al., 1999). Therefore, although many candidates have been proposed so far to mediate insulin responsiveness depending on the context of each gene e.g. FKHR (Durham et al., 1999), Egr-1 (Barroso and Santisteban, 1999), SRF (Thompson et al., 1994), the possibility that insulin could also act independently of IRE by targeting an array of transcription factors at the coactivator level cannot be excluded (Leahy et al., 1999, Pierreux et al., 1999). Particularly, in the case of glucagon gene, it has been suggested that an enhancer-like element called G3 could also act as IRE (Philippe, 1991). However, recent 
results from our laboratory failed to identify a single IRE on glucagon promoter and indicate that insulin responsiveness might rather be due to the synergistic interaction of both proximal promoter and more distal enhancer-like elements with Pax6 and its potential coactivator CREB-binding protein (CPB) being critical components (Grzeskowiak et al., 2000). Glucagon gene expression seems to be controlled by insulin at the transcriptional level through the $\mathrm{PI}(3) \mathrm{K} / \mathrm{PKB}$ pathway (Schinner et al., manuscript in preparation), while it is not known whether any other kinase, downstream of $\mathrm{PKB}$, might be required and/or sufficient to confer insulin responsiveness to the glucagon gene. The pathway remains to be elucidated.

\section{4. 2 Cis-control elements on the glucagon promoter}

Over the last decade substantial amount of data has accumulated concerning the regulation of glucagon gene expression by various transcription factors. By deletional, linker-scanning and DNase I footprint analyses major cis-regulatory elements in the -350 region of the glucagon gene have been identified, which enabled to characterize many trans-acting nuclear proteins (summarized in Knepel, 2001). Transcriptional control elements can be further subdivided into two groups : proximal promoter elements encompassing G1 and G4, and the so called more distal enhancer-like elements including G2, G3 and CRE (Fig.3). The proximal promoter region (base pairs -136 to +58 ) has low transcriptional activity of its own, but is required to mediate activation of transcription by G2 and G3 and may play a role in restricting expression to $\alpha$-cell phenotype cell lines (Philippe et al., 1988, Morell et al., 1995).

The G1 element (base pairs -97 to -65 ) contains AT-rich motifs that bind homeodomaincontaining proteins. Several such proteins have been shown to bind to G1. These include the LIM homeodomain protein Isl-1 (Wang and Sul, 1995), the caudal-related homeodomain cdx2/3 (James et al., 1994, Jin and Drucker 1996, Laser et al., 1996) and the POU domain transcription factor brain-4 (Hussain et al., 1997). In addition, Pax6 (contains two DNAbinding domains : a homeodomain and a paired-domain) interacts also with the G1 element. Pax6 binding to G1 was shown to regulate positively transcription in a synergistic way with cdx-2/3 (Andersen et al., 1999, Ritz-Laser et al.,1999).

Next to G1 is a region called G4 (-150 to $-91 \mathrm{bp})$, containing binding sites for Pdx1 and the basic region helix-loop-helix proteins E2A (E12/E47/E2/5) and Beta2 (Neuro D) (Kruse et al., 1993).

Further upstream two enhancer-like elements are located : G2 (-192 to -174 bp) and G3 (-264 to $-238 \mathrm{bp}$ ) which display islet-specific enhancer-like properties in as much as they enhance expression in some phenotypically distinct pancreatic islet cell lines, but not in several nonislet cell lines.

G2-binding proteins include hepatocyte nuclear factor (HNF)-3 $\alpha, 3 \beta, 3 \gamma$, which are members of the HNF3/forkhead transcription family that share a so called winged-helix DNA-binding domain (Kaufmann and Knöchel, 1996) and can activate glucagon gene transcription. In addition, also Ets-like domain-containing protein (Ets) and NFATp can bind to G2 (Janknecht, 1993, Rao, 1994, Fürstenau et al., 1997, Fürstenau et al., 1999).

The CRE element lies between -291 to -298 and confers activation of glucagon gene transcription in response to elevated cAMP and calcium levels (Knepel et al., 1990a, Meyer and Habener, 1993). The CRE-binding protein CREB belongs to the leucine zipper family of transcription factors. 
Finally, the G3 element (-264 to $-238 \mathrm{bp}$ ) comprises two domains : A and B that bind different nuclear proteins (Knepel et al., 1990b). Transcription factors which bind to G3B were characterised as a heterodimer containing homeodomain proteins Prep/Pbx (Herzig et al., 2000). G3A domain contains a core sequence "TTTYACRCCTSA" which is also found in upstream element (UE) of the rat somatostatin gene, the enhancer 1 element (E1) of the rat insulin I gene and G1 element of rat glucagon gene and is therefore termed pancreatic islet cell-specific enhancer sequence, PISCES (Knepel et al., 1991). Recently it was shown that the paired-box containing factor Pax6 can bind on G3A (Sander et al., 1997). Pax6 has been shown to be crucial for development of endocrine pancreas and in particular for differentiation of $\alpha$-cells (Mansouri et al., 1996).

Recently it has been shown that the carboxy-terminal domain of Pax6 interacts with the coactivator p300/CBP (Hussain and Habener, 1999), suggesting that recruitment of CBP might be important for the function of Pax6 and the rearrangement of other transcription factors to access the general transcriptional machinery on the glucagon promoter.

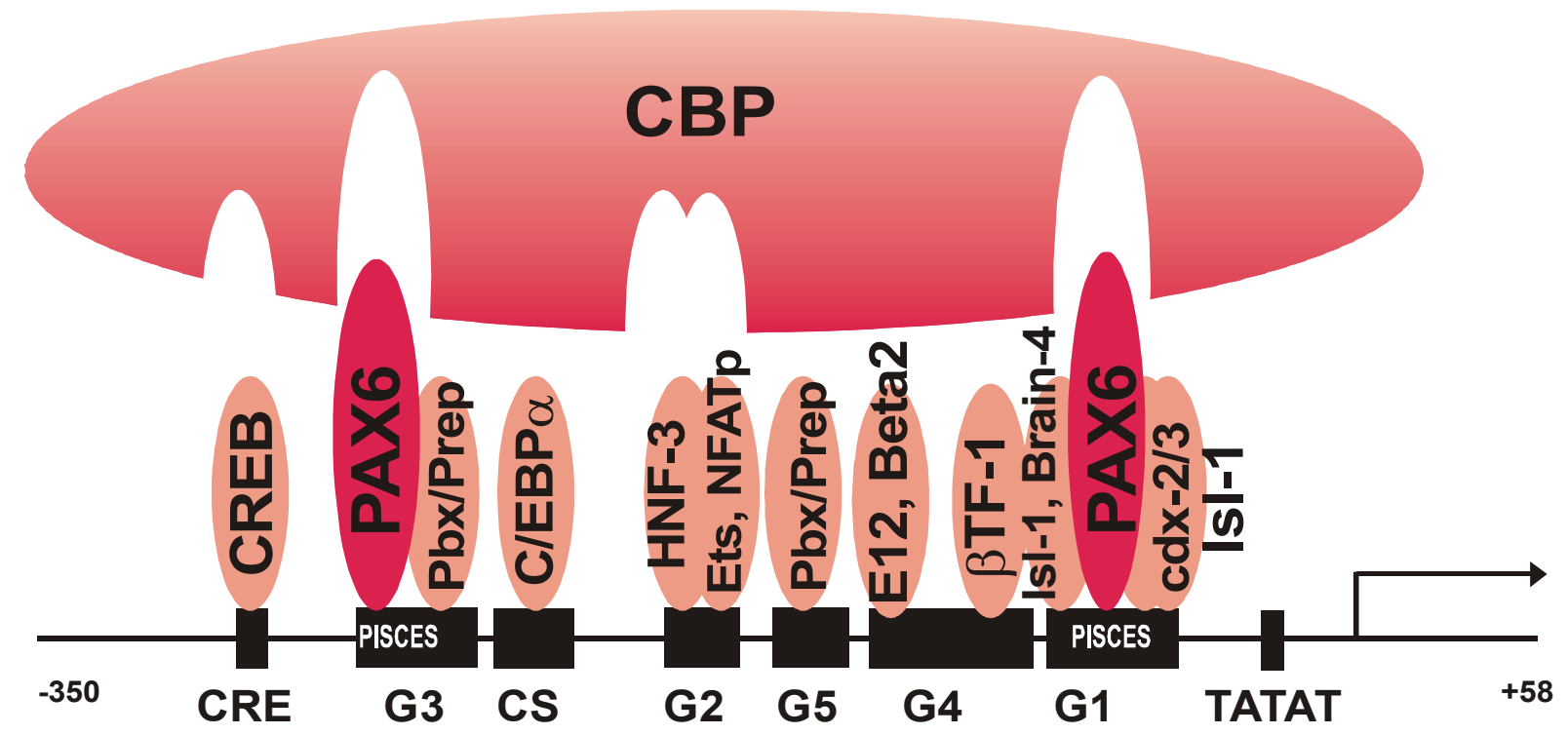

Fig. 3. Control cis-elements on glucagon promoter and their corresponding transcription factors The schema summarizes the so far identified transcription factors that are known to bind on characterized control cis-elements on the glucagon promoter.

None of the transcription factors so far known to bind and regulate glucagon gene expression exhibits a pattern of expression that is restricted exclusively in pancreas. It rather seems that $\alpha$-cell specific activation of glucagon gene is conferred by a unique combinatorial and spatial arrangement of multiple transcription factors that synergistically activate the glucagons gene. It also became apparent that multiple positively acting (cAMP, calcium, PKC, ras) and negatively acting (glucose, insulin) signalling pathways converge on the glucagon gene 5'flanking region (summarized by Knepel, 2001). It is therefore reasonable to assume that these distinct stimuli may participate in a cross talk between intracellular signalling systems, that integrate different stimuli, to an appropriate transcriptional response of the glucagon gene. 


\section{5 Glycogen synthase kinase 3 (GSK3)}

\section{5. 1 Characteristic features of GSK3}

Insulin, upon secretion, binds to its receptor, on the adjacent $\alpha$-cells in pancreas, and initiates a signalling pathway that inhibits glucagon gene transcription (Philippe, 1989). Results from our laboratory suggest that insulin-mediated inhibition is conferred through the $\mathrm{PI}(3) \mathrm{K} / \mathrm{PKB}$ pathway (Schinner et al., manuscript in preparation). In order to characterize the downstream components of this pathway a role for glycogen synthase kinase 3 (GSK3), a well characterized substrate of PKB in insulin signalling (Cross et al., 1995), was investigated in the present study.

GSK3 is a serine/threonine kinase that was identified and named as one of several kinases that phosphorylate and inactivate glycogen synthase, the rate limiting enzyme that catalyses the last step in glycogen synthesis (reviewed by Frame and Cohen, 2001). Insulin-induced activation of glycogen synthase was shown to involve dephosphorylation at those serine residues targeted by GSK3. Despite the specificity inferred by its name it is an important regulatory kinase that participates in a plethora of biological processes and has a great variety of substrates (Grimes and Jope, 2001). GSK3 is an ubiquitously expressed enzyme with orthologues in all eukaryotic organisms examined so far (Ali et al., 2001). It has been implicated in cell fate determination, metabolism, transcriptional control and in mammals in oncogenesis and neurological disorders (Woodgett, 2001, Kaytor and Orr, 2002). Numerous signalling pathways initiated by diverse stimuli control its activity and when dysregulated it has been associated with the development of human diseases such as diabetes, cancer, bipolar disorder, Alzheimer's disease and inflammation (Jope and Bijur, 2002).

There are two mammalian isoforms, which are encoded by distinct genes : GSK3 $\alpha(51 \mathrm{kDa})$ and GSK3 $\beta$ (47 kDa) (Fig.4). The difference in size is due to a glycine-rich extension at the $\mathrm{N}$-terminus of GSK $3 \alpha$. Within their kinase domain they share $98 \%$ identity and isoforms from distant species such as flies and humans display $>90 \%$ sequence similarity within the kinase domain (Doble and Woodgett, 2003). Although both isoforms are structurally highly similar, it became apparent that one cannot compensate always for the other e.g. GSK3 $\beta-/-$ mice die in utero due to extensive hepatocyte apoptosis (Hoeflich et al., 2000). The inability of GSK3 $\alpha$ to rescue the above phenotype indicates that the degenerative liver phenotype arises specifically from the loss of the beta isoform. On the other hand, it is the alpha isoform that has been implicated in the regulation of Alzheimer's disease amyloid- $\beta$ peptides using RNAi (Phiel et al., 2003).

\section{5. 2 Structure of GSK3 and regulation of its enzymatic activity}

Recently the structure of GSK3$\beta$ has been resolved (Dajani et al., 2001, ter Haar et al., 2001) and conforms to the consensus observed for "activation-segment" protein kinases, consisting of an amino-terminal $\beta$-sheet domain coupled to a carboxy-terminal $\alpha$-helical domain. As revealed by sequence comparison GSK3 is related phylogenetically to the family of cyclin dependent kinases (e.g. CDK2) and mitogen activated protein kinases (e.g. p38y). The knowledge of the structure has provided insight into both its regulation and its preference for prephosphorylated substrates. 
The catalytic activity of kinases depends upon the correct conformation of the catalytic groups contributing to the transfer of the $\gamma$-phosphate group from ATP to the recipient residue of the substrate. Equally important is the accessibility and correct positioning of the groups forming the substrate peptide binding site, which provide affinity and specificity for the substrate. These two requirements are often simultaneously contigent upon the conformation of an "activation segment", which contains residues that are themselves subject to phosphorylation. It seems that phosphorylation favors such a conformation of the activation segment in which both the catalytic and the substrate binding sites are correctly formed resulting in a substantial increase in activity (Dajani et al., 2001). GSK3 $\beta$ can achieve a catalytically active conformation even in the absence of any phosphorylation, thus it is always active in resting cells.

Analysis of the structure suggests a mechanism of activation coupled to binding of phosphorylated substrates. Protein kinase related to GSK3 $\beta$ such as p38 $\gamma$ require phosphorylation of residues in their activation loops (T-loops) to become active. A phosphothreonine is used to align key $\beta$-strand and $\alpha$-helical domains. The T-loop of GSK3 $\beta$ is tyrosine phosphorylated (pY216) in resting cells (Hughes et al., 1993, Hartigan et al., 2001, Lesort et al., 1999) but not threonine. Although the physiological significance of Y216 phosphorylation is not yet clear, it might facilitate substrate phosphorylation, but is not strictly required for kinase activity. Activation of GSK3 seems to be analogous to that of MAPKs except that the active conformation is induced not by phosphorylation, but when the phosphorylated residue of a primed substrate binds to a positively charged pocket comprising R96, R180 and K205 for GSK3 $\beta$ (Doble and Woodgett, 2003, Cohen and Frame, 2001) (see Fig.5).

\section{5.3 GSK3 consensus site for phosphorylation}

It seems that most, if not all, of its substrates are prephosphorylated by some other kinase, not always the same, at a priming residue located four residues carboxy-terminal to the site of GSK3 phosphorylation. The consensus sequence for GSK3 substrates is therefore : Ser/Thr$\mathrm{X}-\mathrm{X}-\mathrm{X}-\mathrm{Ser} / \mathrm{Thr}-\mathrm{P}$, where the first Ser/Thr is the target residue, $\mathrm{X}$ is any amino acid and the last Ser/Thr-P is the site of priming phosphorylation (Harwood, 2001).

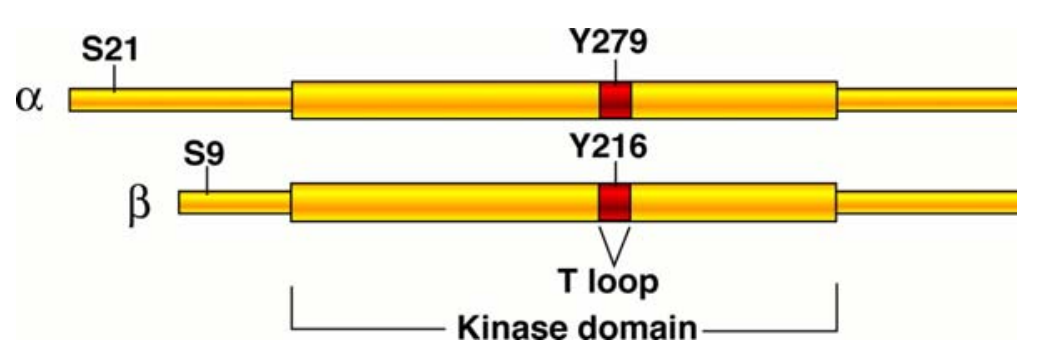

\section{Fig. 4. GSK3 isoforms}

The graph depicts the two isoforms of GSK3. Both of them share $98 \%$ identity within the kinase domain. The alpha isoform is longer due to a glycine-rich extension at the N-terminus. Tyrosine phosphorylation (Tyr279/216) is necessary for activation, while serine phosphorylation accounts for inhibition (Ser21/9). 

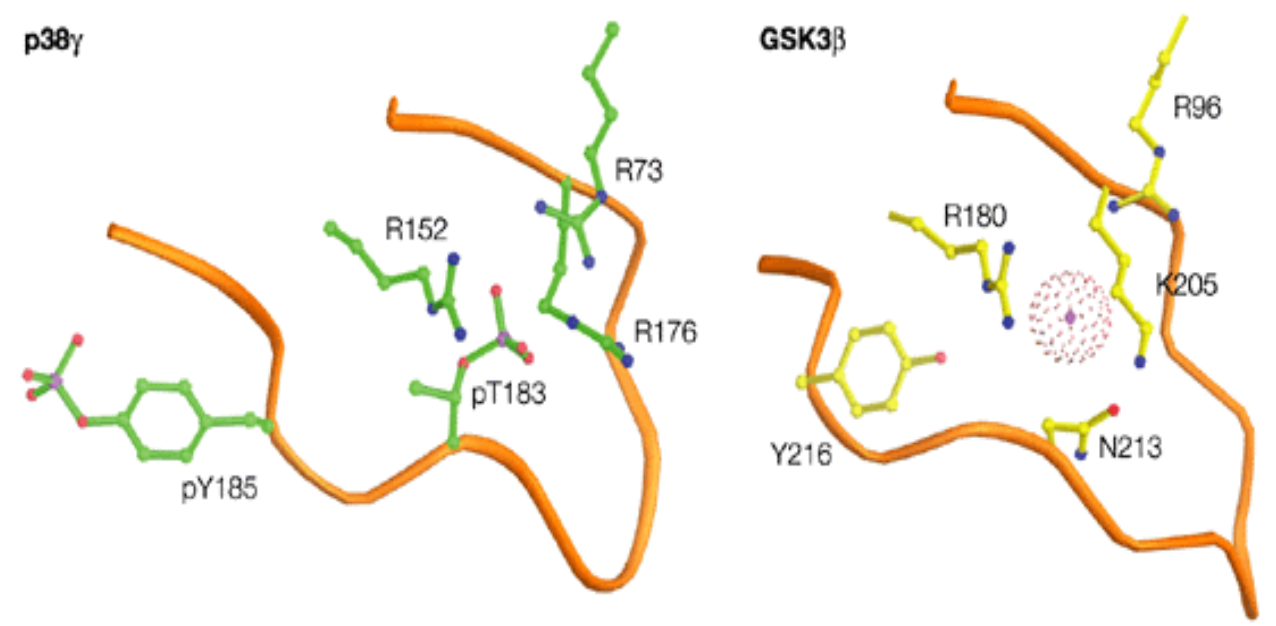

Nat Rev Mol Cell Biol (2001) : 2: 769-776

\section{Fig. 5. Mechanism of activation of GSK3}

The active conformation of MAPK family members is induced by the phosphorylation of T183 and Y185. In this conformation, the pT183 interacts with the basic amino acids R73, R152 and R176, which are equivalent to R96, R180 and K205 of GSK3 $\beta$ respectively, the residues that interact with the priming phosphate of GSK3 $\beta$ substrates. The constitutively pY216 in the activation loop of GSK $3 \beta$ occupies the same position as $\mathrm{Y} 185$ of $\mathrm{p} 38 \gamma$ and acts as a gate for the substrate bindinggroove.

\section{5. 4 PKB mediated inhibition of GSK3}

After binding to its receptor, insulin via PKB phosphorylates GSK3 at a serine residue near the amino terminus (Ser21 for GSK3 $\alpha$ and Ser9 for GSK3 $\beta$ ). This results in inhibition of the catalytic activity, since the amino terminus is transformed into a "pseudosubstrate" inhibitor, the phosphoserine occupies the same binding site as the priming phosphate of the substrate and thus it blocks access to the active site (Cohen and Frame, 2001) (Fig.6). Besides PKB, other kinases as well depending on the stimulus are capable of phosphorylating GSK3 at the same residue and thus controlling its activity e.g. in response to growth factors the most downstream kinase of the classical MAPK pathway (Brady et al., 1998), in response to amino acids p70S6K1 (Armstrong et al., 2001), activators of cAMP-activated protein kinase (PKA) (Fang et al., 2000) and PKC activators (Ballou et al., 2001).

\section{6 GSK3 substrates}

GSK3 phosphorylates a wide spectrum of substrates (summarized in Table 1) including structural proteins, metabolic and signalling proteins, as well as transcription factors. Some of them have been described in detail and the sites phosphorylated are known together with the ultimate effect on substrate function. Interestingly, it seems that in most cases phosphorylation by GSK3 is inhibitory towards transcription factor activation maintaining them in an inactive state under basal conditions. Some of them as a result of phosphorylation are degraded like in the case of $\beta$-catenin (Grimes and Jope, 2001, Woodgett, 2001). Therefore, many different agonists suppress GSK3 activity leading to dephosphorylation of proteins, and subsequent stabilization. 


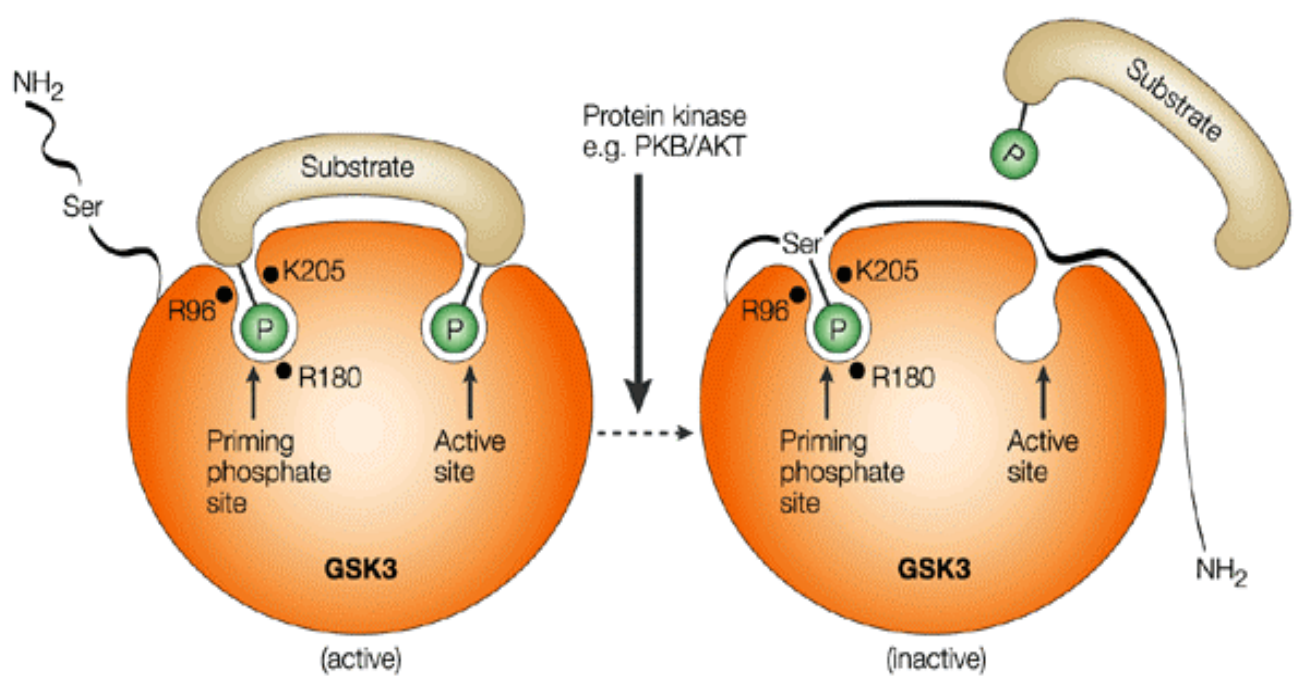

Nat Rev Mol Cell Biol (2001) : 2: 769-776

Fig. 6. Molecular mechanism by which phosphorylation inhibits GSK3 activity

In the absence of insulin, GSK3 is fully active. In this state, substrates that are already prephosphorylated bind to a specific pocket, aligning them in such a way that GSK3 can phosphorylate them at a serine or threonine residue located four amino acids N-terminally to the priming phosphate. After insulin stimulation, GSK3 becomes phosphorylated at a serine residue, which transforms the amino terminus into a "pseudosubstrate" inhibitor, the phosphoserine occupying the same binding site as the priming phosphate of the substrate and blocking access to the active site.

- Table 1 - Putative GSK3 substrates

\begin{tabular}{|c|c|c|c|}
\hline Putative substrate & Function & Effect of phosphorylation & References \\
\hline Glycogen synthase & Glycogen synthesis & Inhibits enzymatic activity & $\begin{array}{l}\text { Dent et al., 1989, } \\
\text { Fiol et al., } 1988\end{array}$ \\
\hline eIF2B & Protein synthesis & Inhibits enzymatic activity & $\begin{array}{l}\text { Welsh and Proud, } \\
1993\end{array}$ \\
\hline ATP citrate lyase & Fatty acid synthesis & Inhibits enzymatic activity & Hughes et al., 1992 \\
\hline Axin & Wnt signalling & Stabilizes protein and recruits $\beta$-catenin & $\begin{array}{l}\text { Ikeda et al., 1998, } \\
\text { Jho et al., } 1999\end{array}$ \\
\hline$\beta$-catenin & Wnt signalling & Targets for degradation & Yost et al., 1996 \\
\hline APC & Wnt signalling & Facilitates binding of $\beta$-catenin to APC & $\begin{array}{l}\text { Rubinfeld et al., } \\
1996\end{array}$ \\
\hline MUC1/DF3 & Glycoprotein & Decreases affinity for $\beta$-catenin & Li et al., 1998 \\
\hline Cyclin D1 & Cell division cycle & $\begin{array}{l}\text { Promotes nuclear export and targets for } \\
\text { degradation }\end{array}$ & Diehl et al., 1998 \\
\hline c-Jun & Transcription factor & Inhibits DNA binding and transactivation & Boyle et al., 1991 \\
\hline c-Myc & Transcription factor & Targets for degradation & $\begin{array}{l}\text { Pulverer et al., } \\
1994\end{array}$ \\
\hline NFATc & Transcription factor & $\begin{array}{l}\text { Promotes nuclear export ; inhibits DNA } \\
\text { binding }\end{array}$ & Beals et al., 1997 \\
\hline $\mathrm{C} / \mathrm{EBP} \alpha$ & Transcription factor & Not well studied & Ross et al., 1999 \\
\hline
\end{tabular}




\begin{tabular}{|c|c|c|c|}
\hline CREB & Transcription factor & Inhibits DNA binding & $\begin{array}{l}\text { Grimes and Jope, } \\
2001\end{array}$ \\
\hline HSF-1 & Transcription factor & Inhibits DNA binding and transactivation & Chu et al., 1996 \\
\hline GATA4 & Transcription factor & Suppresses nuclear expression & \begin{tabular}{|l} 
Morisco et al., \\
2001
\end{tabular} \\
\hline Tau & $\begin{array}{l}\text { Microtubule binding- } \\
\text { protein }\end{array}$ & Inhibits binding to microtubules & Hanger et al., 1992 \\
\hline MAP1B & $\begin{array}{l}\text { Microtubule binding- } \\
\text { protein }\end{array}$ & Maintains microtubular instability & $\begin{array}{l}\text { Garcia-Perez et al., } \\
1998\end{array}$ \\
\hline Presenilin-1 & $\begin{array}{l}\text { Transmembrane } \\
\text { protein }\end{array}$ & $\begin{array}{l}\text { Increases degradation of C-terminal } \\
\text { fragments }\end{array}$ & $\begin{array}{l}\text { Kirschenbaum et } \\
\text { al., } 2001\end{array}$ \\
\hline IRS-1 & Insulin signalling & Inhibits insulin signalling & $\begin{array}{l}\text { Eldar-Finkelman } \\
\text { and Krebs, } 1997\end{array}$ \\
\hline Inhibitor-2 & $\begin{array}{l}\text { Regulatory subunit of } \\
\text { phosphatase }\end{array}$ & Activates phosphatase & Park et al., 1994 \\
\hline
\end{tabular}

\section{7 The Wnt pathway}

It seems that GSK3 exists in two pools (Fig.7) within the cells : one free in cytosol and another as a part of a multiprotein complex in Wnt signalling together with axin, adenomatous polyposis coli (APC) and $\beta$-catenin (Weston and Davis, 2001). In the absence of secreted glycoproteins, termed as Wnts, GSK3 is active and phosphorylates axin, APC and $\beta$-catenin (Dominguez and Green, 2001). As a result axin is stabilized, but $\beta$-catenin becomes target for ubiquitylation and subsequent proteolytic degradation. After binding of Wnts to their receptors, a signal transduction pathway is triggered, which remains to be fully elucidated, that seems to involve a protein termed dishevelled (DSH) which together with FRAT (frequently rearranged in advanced T-cell lymphomas) results in the displacement of axin. GSK3 cannot phosphorylate any longer $\beta$-catenin, which accumulates and translocates into the nucleus, where it functions as a coactivator binding members of the T-cell factor (TCF) family of transcription factors and stimulates transcription of target genes (Woodgett, 2001). It is of interest to observe that most of these proteins when abnormally regulated have been found to be associated with various types of cancer.

Although initially it was assumed that GSK3 phosphorylates substrates of the Wnt pathway in a manner that does not require prephosphorylation (Frame et al., 2001) recently several groups have independently identified casein kinase I as a priming kinase for $\beta$-catenin (Amit et al., 2002, Yanagawa et al., 2002, Liu et al., 2002).

Despite their common GSK3 component, the Wnt and the insulin signalling pathways are insulated from each other by effective sequestration of a fraction of GSK3 in the axin destruction complex (Ding et al., 2000). 


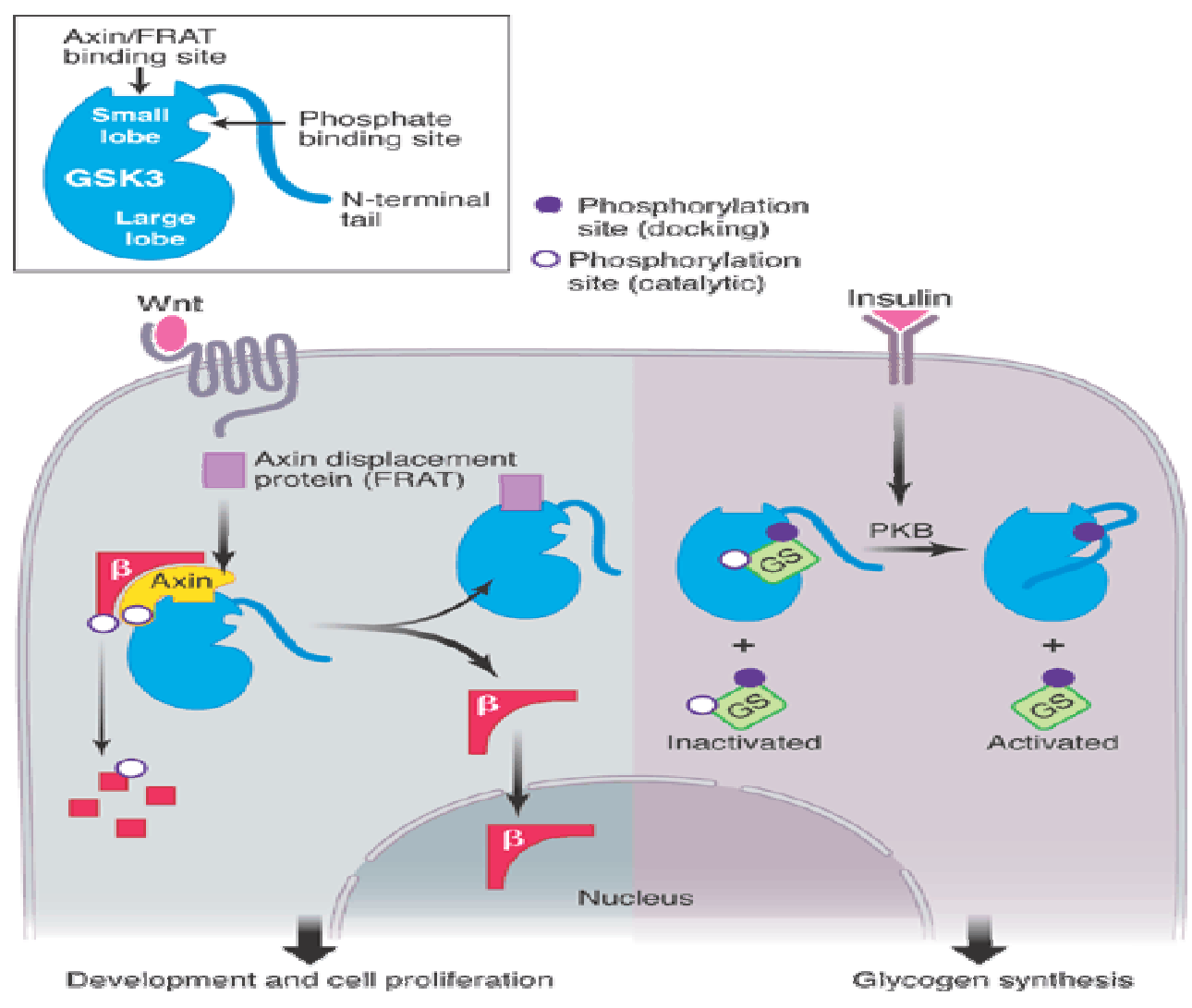

Science (2001) ; 292: 2439-2440

Fig. 7. GSK3 pools within the cell

(left) When Wnt binds to its receptor, proteins such as FRAT displace axin from the complex with GSK3 resulting in accumulation of $\beta$-catenin in the cytosol, which then translocates into the nucleus to regulate gene expression. (right) Binding of insulin to its receptor results in activation of PKB, which phosphorylates and inhibits not-bound to axin complex GSK3. Therefore, the effects of insulin are restricted to a specific substrate of GSK3 substrates.

\section{8 GSK3 inhibitors}

Since GSK3 is involved in numerous biological functions and abnormal regulation is associated with various diseases, it is emerging as a major therapeutical target (EldarFinkelman, 2002, Martinez et al., 2002). For that reason, in the past years several chemically distinct small molecule inhibitors of GSK3 have been developed (summarized in Table 2) in addition to lithium, which was the first compound to be characterized. Most GSK3 inhibitors act in an ATP-competitive manner, while some compete for magnesium (Martinez et al., 2002a).

Some of these compounds have insulin-mimetic action, which makes them candidates to cure type 2 diabetes mellitus. Since their specificity was determined in vitro within the range of kinases tested, their in vivo mode of action remains to be validated. In addition to the problem of its broad range of functions, inhibition of GSK3 could lead to elevated levels of $\beta$-catenin, a known oncogene linked to colorectal cancer. Therefore, there is a need for drugs that selectively target non-axin-associated GSK3, especially in the case of treatment of chronic diseases such as diabetes (Doble and Woodgett, 2003). 
- Table 2 - GSK3 inhibitors

\begin{tabular}{|l|l|l|l|}
\hline Drug type & Mode of action & Effect & References \\
\hline Aloisines & ATP-competitive & Inhibits cell proliferation & Mettey et al., 2003 \\
\hline Indirubins & ATP-competitive & Anti-tumoral & Leclerc et al., 2001 \\
\hline Paullones & ATP-competitive & Inhibits tau phosphorylation & Leost et al., 2000 \\
\hline Hymenialdisine & ATP-competitive & Suppresses inflammation & Meijer et al., 2000 \\
\hline Maleimides & ATP-competitive & $\begin{array}{l}\text { Insulin-mimetic } \text {; prevention of } \\
\text { apoptosis }\end{array}$ & $\begin{array}{l}\text { Coghlan } \text { et al., 2000, } \\
\text { Cross } \text { et al., 2001 }\end{array}$ \\
\hline Lithium & Competes for Mg++ & Mood stabilizer & Klein and Melton, 1996 \\
\hline Valproate & Not known & Mood stabilizer & Chen et al., 1999 \\
\hline Muscarinic agonists & Not known & Inhibits tau phosphorylation & Forlenza et al., 2000 \\
\hline Thiadiazolidinones & Not known & Inhibits tau phosphorylation & Martinez et al., 2002 \\
\hline Beryllium & Competes for Mg++ & No data & Ryves et al., 2002 \\
\hline Bivalent zinc & Not known & Insulin-mimetic & Ilouz et al., 2002 \\
\hline Chiron compounds & ATP-competitive & Insulin-mimetic & Ring et al., 2003 \\
\hline
\end{tabular}

\subsection{Aim of the study}

The aim of the present work was to study the regulation of glucagon gene transcription by GSK3 and to examine whether it might be involved in the insulin signalling pathway that confers inhibitory regulation to glucagon gene expression.

For that reason, transient transfection assays were performed in the glucagon producing cell line, InR1G9, using various glucagon-reporter fusion genes and employing the Gal4 system as well, while protein levels were monitored by immunoblot analysis and immunofluorescence studies, and enzymatic activity was examined by in vitro assays. 


\section{MATERIALS and METHODS}

\section{1 MATERIALS}

\section{1. 1 Instruments}

Autoclave

Balances

Camera

Cell culture hood

Centrifuges

Drying apparatus

Electrophoresis chamber (DNA)

Electrophoresis chamber (protein)

Electrophoresis power supply

Freezers

GFP

Heat block

Incubator for bacterial culture

Light microscope

Luminometer

Fluorescent microscope

Microwave oven

PCR

$\mathrm{pH}$ meter

Phosphoimager

Pipettes

Pipettus akku

Radioactivity counter

Refrigerator

Rotators
Bioclav, Schütt Labortechnik, Göttingen

Sartorius AG, Göttingen

Hamamatsu Digital CCD Kamera, C4742-95,

Hamamatsu-city, Japan

Lamin Air, Heraeus, Hanau

i)Megafuge-Biofuge, Heraeus $\mathrm{GmbH}$, Hanau

ii)Eppendorf 5417R, Eppendorf GmbH Hamburg

iii)Beckman J2-HS, Beckman GmbH, Krefeld

iv)Ultracentrifuge L8-70M Beckman ${ }^{\circledR}$,

Beckman, Krefeld

Dry Gel SR, Hoefer Scientific Instruments, San

Francisco, USA

Roth, Karlsruhe

Mighty Small SE 250/SE 260, Hoefer, San

Francisco, USA

Biometra, Göttingen

Sanyo, Japan

Fusion $^{\mathrm{TM}}$, Packard, Switzerland

W.Krannich GmbH, Göttingen

Heraeus GmbH, Hanau

Nikon, Japan

AutoLumat LB 953, Berthold Technologies, Bad

Wildbad

Carl Zeiss Inverted Microscope Axiovert 200, Jena

Philips, Whirlpool, UK

Biometra Trio-Thermoblock, Göttingen

pH 523, Schütt Labortechnik, Göttingen

Raytest, Fujifilm BAS-1500, Stuttgart

Gilson, France

Hirschmann Laborgeräte, Göttingen

Beckman LS 1801, Beckman GmbH, Krefeld

Bosch, Göttingen

W.Krannich GmbH, Göttingen 
Rotors

Scanner

Scintillation counter

Shakers

Sonicators

Speedvac

Spectrophotometer

Thermomixer

UV light

Video Copy Processor

Vortexer

Waterbaths

\section{1. 2 Consumables}

Cell culture plastic equipment

ECL - X ray films

Falcon tubes

Filters

Glass coverslips

Glass slides

Membrane

Pasteur pipettes

Pipette tips

Plastic tubes

PCR tubes

Spectrophotometer cuvettes

Ultracentrifuge tubes

Whatman paper P81
Beckman Rotors JA-20/JA17/JA14, Beckman

$\mathrm{GmbH}$, Krefeld

Duoscan T1200 Agfa, Cologne

Beckman LS 1801, Beckman, Krefeld

Rocking Platform, Biometra, Göttingen

Sonifier, Cell Disruptor B-15, Branson, Geneva,

Switzerland

Heto VR-I, Hetovac

Shimadzu UV-160, Duisburg

Eppendorf, Hamburg

UV Kontaktlampe Chroma 41, Kurzwelle254nm, Schütt Labortechnik, Göttingen

Mitsubishi, Herolab, Molekulare Trenntechnik, Wiesloch

Janke \& Kunkel IKA-Labortechnik, Göttingen

W.Krannich GmbH, Göttingen
Becton Dickinson, France

Amersham Biosciences, UK

Cell star ${ }^{\circledR}$, Greiner Bio-one, Solingen

Sartorius, Göttingen

W.Krannich GmbH, Göttingen

W.Krannich GmbH, Göttingen

Hybond $^{\mathrm{TM}}$ ECL $^{\mathrm{TM}}$ Nitrocellulose membrane,

Amersham Pharmacia Biotech, UK

Brand, Wertheim/Main

Sarstedt, Nümbrecht

Sarstedt, Nümbrecht

Sarstedt, Nümbrecht

Sarstedt, Nümbrecht

Beckman GmbH, Krefeld

Whatman, Maidstone, UK

\section{1.3 Antibiotics}

penicillin $(10,000 \mathrm{U} / \mathrm{ml})$ - streptomycin $(10,000 \mu \mathrm{g} / \mathrm{ml})$ in solution (GIBCO-BRL, Karlsruhe) 


\section{1. 4 GSK3 inhibitors}

SB-216763 developed by GlaxoSmithKline available through Tocris No\#1616 SB-415286 developed by GlaxoSmithKline available through Tocris No\#1617 Indirubin-3'-monoxime, kindly provided by Prof. L. Meijer, Roscoff, France Alsterpaullone, kindly provided by Prof. L. Meijer, Roscoff, France Chiron compound, CT-98023, Chiron Corporation, Emeryville, USA Lithium Chloride anhydrous, Sigma L-0505, Taufkirchen Lithium Acetate dihydrate, Sigma L-4158, Taufkirchen Valproic acid (2-propylpentanoic acid sodium), Sigma P-4543, Taufkirchen

- Table 3 - Chemical structure of the various GSK3 inhibitors

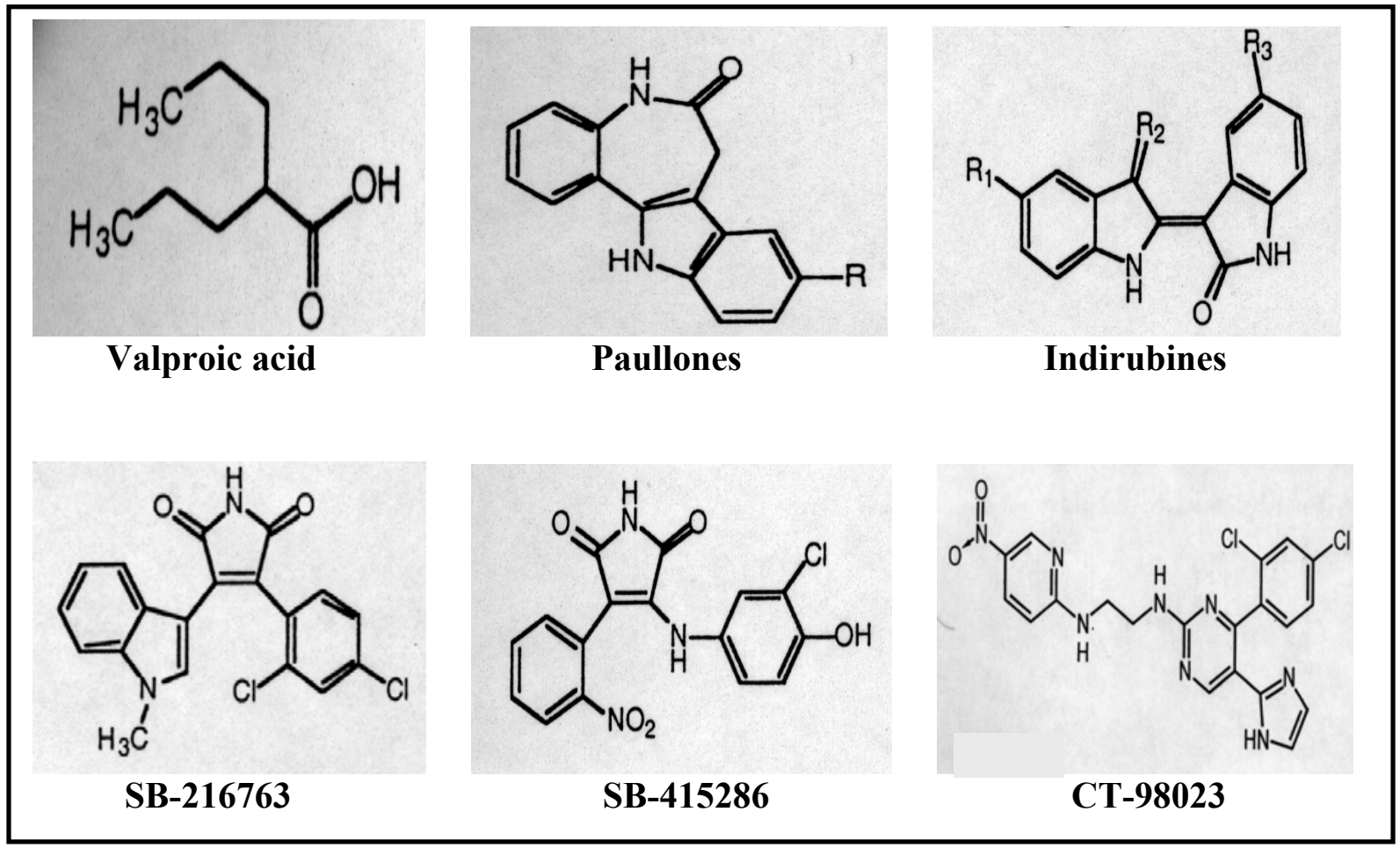

\section{1. 5 General Chemicals}

Acrylamide

Agarose

Ampicillin

APS

Aprotinin

Aqua ad injectabilia

ATP
Serva, Heidelberg

Invitrogen, UK

Applichem, Darmstadt

Sigma, Taufkirchen

Sigma, Taufkirchen

Braun, Melsungen

Sigma, Taufkirchen 
Bis-acrylamide

Bromophenol blue

BSA

DAPI

DEAE-Dextran

DMSO

DTT

EDTA

EGTA

Ethanol

Ethidium bromide

Glucose

Glutathione reduced form

Glutathione Agarose beads

Glycerol

Glycylglycine

IPTG

Isopropanol

Leupeptin

Luciferin

Lysozyme

LY-294002

Mineral oil

Paraformaldehyde

PEG

Pepstatin

PMSF

Poly-L-lysine

Potassium chloride

SDS

Sodium chloride

Sucrose

TEMED

Tris

Triton X-100

Tween 20

- Radiochemical

$\gamma{ }^{32} \mathrm{P}$-ATP $(250 \mu \mathrm{Ci}, 3000 \mathrm{Ci} / \mathrm{mmol})$
Serva, Heidelberg

Sigma, Taufkirchen

Applichem, Darmstadt

Sigma, Taufkirchen

Pharmacia, UK

Sigma, Taufkirchen

Applichem, Darmstadt

Applichem, Darmstadt

Applichem, Darmstadt

Applichem, Darmstadt

Sigma, Taufkirchen

Applichem, Darmstadt

Sigma, Taufkirchen

Sigma, Taufkirchen

Applichem, Darmstadt

Applichem, Darmstadt

Sigma, Taufkirchen

Applichem, Darmstadt

Sigma, Taufkirchen

Sigma, Taufkirchen

Sigma, Taukirchen

Calbiochem, San Diego, USA

Sigma, Taufkirchen

Sigma, Taufkirchen

Applichem, Darmstadt

Sigma, Taufkirchen

Applichem, Darmstadt

Sigma, Taufkirchen

Applichem, Darmstadt

Applichem, Darmstadt

Applichem, Darmstadt

Applichem, Darmstadt

Applichem, Darmstadt

Applichem, Darmstadt

Sigma, Taufkirchen

Sigma, Taufkirchen

Amersham Biosciences, UK 


\section{1. 6 Kits}

Agarose Gel Extraction Kit

Maxiprep Star
Easy Pure, Biozym, Oldendorf

Genomed, Bad Oeynhausen

\section{1. 7 Bacterial culture materials}

select-agar (GIBCO-BRL, Karlsruhe), select-peptone (GIBCO-BRL, Karlsruhe), select-yeast extract (GIBCO-BRL, Karlsruhe), petri-dishes (10 cm) (Greiner, Frickenhausen)

$\underline{\text { LB (luria - bertani )medium : }}$

Select peptone

Select yeast extract

$\mathrm{NaCl}$

$$
\begin{array}{rr}
1 \% & (\mathrm{w} / \mathrm{v}) \\
0.5 \% & (\mathrm{w} / \mathrm{v}) \\
1 \% & (\mathrm{w} / \mathrm{v})
\end{array}
$$

For preparing agar plates agar $(1.5 \%, \mathrm{w} / \mathrm{v})$ was added to LB medium plus ampicillin (50 $\mu \mathrm{g} / \mathrm{ml})$. The medium was autoclaved for $20 \mathrm{~min}$ at $120^{\circ} \mathrm{C}$ at $15 \mathrm{psi}$.

\section{1. 8 Eukaryotic cell line}

The following cell line was used : glucagon-producing Golden Hamster pancreatic tumor cell line, InR1G9 ( $\alpha$-cell phenotype) (Takaki et al., 1986).

\section{1.9 Eukaryotic cell culture materials}

RPMI 1640 medium and FCS (GIBCO-BRL, Karlsruhe)

Trypsin-EDTA, unit 100 ML (GIBCO-BRL, Karlsruhe)

Falcon-dishes (Becton, Dickson, UK)

Media for eukaryotic InR1G9 cells :

RPMI medium (1 L) : RPMI 1640 medium powder, $\mathrm{NaHCO}_{3} 2 \mathrm{~g}$, volume adjusted to $1 \mathrm{~L}$ with distilled water and filter sterilised

Complete medium :
RPMI medium
ad $500 \mathrm{ml}$
Fetal bovine serum
$50 \mathrm{ml}$
Penicillin-streptomycin solution
$5 \mathrm{ml}$ 
BSA containing medium :

$\begin{array}{lr}\text { RPMI medium } & \text { ad } 500 \mathrm{ml} \\ \text { BSA } & 2.5 \mathrm{~g} \\ \text { Penicillin-streptomycin solution } & 5 \mathrm{ml}\end{array}$

Sterilize through filter $0.2 \mu \mathrm{m}$ (Sartorius, Göttingen)

\subsubsection{General buffers and media}

Routinely used buffers and media were prepared according to 'Molecular Cloning' laboratoy manual (Sambrook et al., 1989) :

$\underline{1 \times \text { PBS : }}$

$\mathrm{NaCl}$

$140 \mathrm{mM}$

$\mathrm{KCl}$

$2.5 \mathrm{mM}$

$\mathrm{Na}_{2} \mathrm{HPO}_{4}$

$8.1 \mathrm{mM}$

$\mathrm{KH}_{2} \mathrm{PO}_{4}$

$1.5 \mathrm{mM}$

$\mathrm{pH}$ adjusted to 7.4

$\underline{50 \times \mathrm{TAE}:}$

Tris

EDTA

$50 \mathrm{mM}$

Acetic acid

$4 \%$

pH 8.5

$1 \times \mathrm{TE}$ :

Tris $\mathrm{pH} 8.0$

EDTA pH 8.0

$10 \mathrm{mM}$

$1 \mathrm{mM}$

Stock solutions :

Ampicillin

Chloramphenicol

Dithiothreitol

ATP

PMSF
$50 \mathrm{mg} / \mathrm{ml}$ (in water)

$34 \mathrm{mg} / \mathrm{ml}$ (in ethanol)

$1 \mathrm{M}$ (in water)

$200 \mu \mathrm{M}$ (in water)

$250 \mu \mathrm{M}$ (in ethanol)

If not otherwise mentioned organic liquid buffers and reagents were purchased from Applichem, Darmstadt. 


\subsubsection{Reporter gene plasmids and expression plasmids}

\begin{tabular}{|c|c|}
\hline Reporter gene construct & Reference \\
\hline -350GluLuc & Schwaninger et al., 1993 \\
\hline -292GluLuc & Fürstenau et al., 1997 \\
\hline -200GluLuc & Fürstenau et al., 1997 \\
\hline -169GluLuc & Fürstenau et al., 1997 \\
\hline$-60 \mathrm{GluLuc}$ & Fürstenau et al., 1997 \\
\hline pT81Luc & Nordeen 1988 \\
\hline$-350 /-48$ GluLuc & Fürstenau et al., 1997 \\
\hline$-350 /-91 \mathrm{GluLuc}$ & Fürstenau et al., 1997 \\
\hline$-350 /-150$ GluLuc & Fürstenau et al., 1997 \\
\hline$-350 /-210$ GluLuc & Fürstenau et al., 1997 \\
\hline$-350(\mathrm{G} 1 \mathrm{~m})$ GluLuc & Teichler (research group Prof.Knepel) \\
\hline$-350(\mathrm{G} 3 \mathrm{Am})$ GluLuc & Teichler (research group Prof.Knepel) \\
\hline$-350(\mathrm{G} 1 \mathrm{~m}+\mathrm{G} 3 \mathrm{Am}) \mathrm{GluLuc}$ & Teichler (research group Prof.Knepel) \\
\hline$-350($ mutG1/G3)GluLuc & Grzeskowiak et al., 2000 \\
\hline 5xGal4(E1B)Luc & Krüger et al., 1997 \\
\hline$-711 \mathrm{c}-\mathrm{fosLuc}$ & Schwaninger et al., 1993 \\
\hline
\end{tabular}

\begin{tabular}{|c|c|}
\hline Expresion plasmids & Reference \\
\hline GSK3 $3 w t$ & Research group Prof.Knepel \\
\hline GSK3ßR85 & Research group Prof.Knepel \\
\hline GSK3 $\beta A 9$ & Shaw et al., 1997 \\
\hline GAL4-Pax6 & Grzeskowiak et al., 2000 \\
\hline GAL-CPB8 (full length) & Chrivia et al., 1993 \\
\hline GAL4-CBP [1-451] & Kurokawa et al., 1998 \\
\hline GAL4-CBP [1892-2441] & Kurokawa et al., 1998 \\
\hline GAL4-CBP [1062-1891] & Kurokawa et al., 1998 \\
\hline GAL4-CBP [1880-2441] & research group Prof.Knepel \\
\hline GAL4-CBP [2040-2441] & research group Prof.Knepel \\
\hline GAL4-CBP [2040-2170] & research group Prof.Knepel \\
\hline GAL4-CBP [2306-2441] & research group Prof.Knepel \\
\hline GAL4-CBP [2171-2441] & research group Prof.Knepel \\
\hline
\end{tabular}

Detailed description for the constructs GSK3 $\beta w t$ and GSK3 $\beta$ R85 can be found in 2.2.1.9 in Materials and Methods. The rest plasmids, that have been used but not prepared in this study, have been described elsewhere (see the relevant references). The plasmid pCMV-GFPtpz was purchased from Canberra-Packard, Dreieich, Germany. The plasmid pBP (Bluescript) was purchased from Stratagene, Germany. 


\section{1. 12 Antibodies, proteins, peptides, molecular weight standards and enzymes}

primary antibodies

- anti-GSK3, clone 4G-1E, mouse monoclonal $\operatorname{IgG}_{1}$, Upstate Biotechnology (\#05-412), Lake Placid, NY, USA

- phospho-GSK3 $\alpha / \beta$ (Ser21/9), rabbit polyclonal, New England Biolabs (\#9331), Beverly, MA, USA

- $\quad \beta$-catenin, mouse IgG $_{1}$, clone 14, BD Transduction Laboratories (\#610153), Oxford, UK

secondary antibodies

- $\mathrm{Cy}^{\mathrm{TM}} 2$-conjugated AffiniPure goat anti-mouse $\operatorname{IgG}(\mathrm{H}+\mathrm{L})$, Jackson Immunoresearch Laboratories (\#115-225-003), West Grove, PA, USA

- peroxidase labelled anti-mouse and peroxidase labelled anti-rabbit ECL ${ }^{\mathrm{TM}}$ western blotting detection reagents, Amersham Biosciences (\#RPN 2106), UK

protein

- GSK3 $\beta$, active, Upstate Biotechnology (\#14-306), Lake Placid, NY, USA

peptides

- phospho-glycogen synthase peptide-2, Upstate Biotechnology (\#12-241), Lake Placid, NY, USA (substrate peptide)

- glycogen synthase peptide-2 (Ala21), Upstate Biotechnology (\#12-242), Lake Placid, NY, USA (control peptide)

protein marker

- Protein Marker BOA, Biomol (\#55875), Hamburg

- SDS 7B, SDS molecular weight standard mixture, Sigma, Taufkirchen

DNA marker

- Gene ruler 1Kb DNA ladder, MBI Fermentas (\#SM0313), St.Leon-Rot

The rest of the enzymes used including restriction endonucleases, T4-DNA ligase, Klenow DNA polymerase, Taq DNA polymerase and alkaline phosphatase were purchased from MBI Fermentas, St.Leon-Rot, Germany. 


\section{2 METHODS}

\section{2. 1 Standard methods of molecular cloning}

\section{2. 1. 1 Preparation of competent Escherichia coli bacteria}

Competent bacteria were produced by modification of the cell wall, which facilitates DNA uptake. $100 \mathrm{ml}$ of LB medium was inoculated with a single colony of Escherichia coli strain $\mathrm{DH} 5 \alpha$ and culture was grown at $37^{\circ} \mathrm{C}, 200 \mathrm{rpm}$, until $\mathrm{OD} 600$ reached 0.6. Bacteria were centrifuged for $10 \mathrm{~min}$ at $4^{\circ} \mathrm{C}, 3,000 \mathrm{rpm}$, and the pellet was resuspended in $50 \mathrm{ml}$ of sterile $50 \mathrm{mM} \mathrm{CaCl}_{2}$ at $4^{\circ} \mathrm{C}$ and incubated on ice for $30 \mathrm{~min}$. The suspension was centrifuged for 10 min at $4{ }^{\circ} \mathrm{C} \mathrm{3,000} \mathrm{rpm} \mathrm{and} \mathrm{the} \mathrm{pellet} \mathrm{was} \mathrm{resuspended} \mathrm{in} 10 \mathrm{ml}$ of sterile $50 \mathrm{mM} \mathrm{CaCl}_{2}$ with $15 \%$ glycerol. The mixture was dispensed into aliquots of $100 \mu \mathrm{l}$ and stored at $-80^{\circ} \mathrm{C}$.

\section{2. 1. 2 Transformation of competent bacteria}

Transformation was carried out by gentle mixing and incubating an aliquot of $100 \mu \mathrm{l}$ competent cells with $50 \mathrm{ng}$ of plasmid DNA for $45 \mathrm{~min}$ on ice. After the incubation the mixture was further processed for "heat shock", $30 \mathrm{sec}$ at $42^{\circ} \mathrm{C}$. The cells were then placed on ice for 2-3 min and incubated with $1 \mathrm{ml} \mathrm{LB}$ medium without antibiotics at $37^{\circ} \mathrm{C}$ for $1 \mathrm{~h}$ under constant agitation, $225 \mathrm{rpm}$, to recover and to express the plasmid genes. The whole transformation mixture was then used and plated on LB agar plates, plus antibiotics, overnight at $37^{\circ} \mathrm{C}$ in the incubator.

\section{2. 1.3 Mini preparation of plasmid DNA}

A modified alkaline lysis method was used to purify plasmid DNA. A single colony was inoculated into $5 \mathrm{ml}$ of LB medium plus ampicillin and grown overnight at $37^{\circ} \mathrm{C}, 220 \mathrm{rpm}$. Then bacterial culture was subject to the following protocol :

$1.5 \mathrm{ml}$ of culture was centrifuged at $4^{\circ} \mathrm{C}, 6,000 \mathrm{rpm}$ for $5 \mathrm{~min}$ (Eppendorf 5415C). The pellet was resuspended in $100 \mu \mathrm{l}$ of Solution I. Next, $200 \mu \mathrm{l}$ of Solution II was added plus $200 \mu \mathrm{l}$ of chloroform and the tube was carefully inverted to mix. After 1 min of lysis, $150 \mu 1$ of ice cold Solution III was added and the mixture was vortexed shortly.

The mixture was centrifuged at RT for $2 \mathrm{~min}, 14,000 \mathrm{rpm}$. The upper phase was taken (approximately $360 \mu \mathrm{l}$ ) and was precipitated with one volume of $100 \%$ isopropanol. The mixture was centrifuged at $4^{\circ} \mathrm{C}$ for $5 \mathrm{~min}, 14,000 \mathrm{rpm}$, and after this step the supernatant was discarded. 
The pellet was washed twice with $80 \%$ ethanol and then dried under vacuum. Dry pellet was redissolved in $20 \mathrm{ml}$ of RNase I solution ( $1 \mu \mathrm{g}$ in $1 \mathrm{ml}$ of TE buffer) and incubated at $37^{\circ} \mathrm{C}$ for $1 \mathrm{~h}$ (RNA digestion). Then, plasmid was stored at $4^{\circ} \mathrm{C}$.

Solution I : $50 \mathrm{mM}$ glucose, $10 \mathrm{mM}$ EDTA, $25 \mathrm{mM}$ Tris $\mathrm{pH} 8.0$

Solution II : $0.2 \mathrm{~N} \mathrm{NaOH}, 1 \% \mathrm{SDS}$

Solution III : $29.4 \mathrm{~g} \mathrm{KAc}, 5 \mathrm{ml} \mathrm{HCOOH}$ and water to $100 \mathrm{ml}$

\section{2. 1. 4 Maxi preparation of plasmid DNA}

Large amounts of plasmid DNA (1-2 mg) were produced using preparative ultracentrifugation of bacterial lysate in a $\mathrm{CsCl}$ gradient as following :

$15 \mathrm{ml}$ of LB medium, plus ampicillin at final concentration $50 \mu \mathrm{g} / \mathrm{ml}$, was inoculated with a single colony. The culture was grown overnight in a rotary shaker $225 \mathrm{rpm}$ at $37^{\circ} \mathrm{C}$. Next, 1 liter of LB medium plus amp was inoculated with the preculture and grown at $37^{\circ} \mathrm{C}$, until the OD 600 reached $0.8-1.0$, and then chloramphenicol was added to final concentration of 200 $\mathrm{mg} / \mathrm{L}$. The culture was further incubated in rotary shaker $225 \mathrm{rpm}$ at $37^{\circ} \mathrm{C}$ for additional 12 h. The $1 \mathrm{~L}$ culture was centrifuged at 10,000 rpm (Beckman JA-14 Rotor) for $15 \mathrm{~min}$ at $4^{\circ} \mathrm{C}$. The pellet was resuspended in $45 \mathrm{ml}$ ice cold STE (25\% saccharose, $1 \mathrm{mM}$ EDTA, $50 \mathrm{mM}$ Tris $\mathrm{pH} 8.0)$ and $3 \mathrm{ml}$ of lysozyme was added $(60 \mathrm{mg} / \mathrm{ml}$ in STE). After incubation for 20 min on ice, $3.6 \mathrm{ml}$ of $0.5 \mathrm{M}$ EDTA was added and the mixture was incubated for $5 \mathrm{~min}$ on ice. Then, $28.8 \mathrm{ml}$ of Triton-mix was added $(0.1 \%$ Triton X-100, $50 \mathrm{mM}$ Tris $\mathrm{pH} 8.0,60 \mathrm{mM}$ EDTA). The mixture was incubated on ice for $30 \mathrm{~min}$ (shaking every $5 \mathrm{~min}$ ).

The mixture was centrifuged for $1 \mathrm{~h}$ at 16,000 rpm (Beckman JA-20 Rotor) at $4^{\circ} \mathrm{C}$. Next, 40 $\mathrm{ml}$ of $30 \%$ PEG was added to the supernatant (30\% PEG 6000, $1.5 \mathrm{M} \mathrm{NaCl})$ and the mixture was incubated for $1 \mathrm{~h}$ on ice. The mixture was centrifuged for $10 \mathrm{~min}$ at 10,000 rpm (Beckman JA-14 Rotor) at $4^{\circ} \mathrm{C}$ and the supernatant was discarded.

The pellet was resuspended in $10 \mathrm{ml}$ of TNE buffer $(10 \mathrm{mM}$ Tris $\mathrm{pH} 8.0,10 \mathrm{mM} \mathrm{NaCl}, 1$ mM EDTA) and $10.9 \mathrm{~g}$ of $\mathrm{CsCl}$ plus $150 \mu \mathrm{l}$ of ethidiumbromide $(10 \mathrm{mg} / \mathrm{ml})$ was added. The solution was pipetted into an ultracentrifuge tube and weighted. The difference between the tubes should not be more than $0.05 \mathrm{~g}$. The tubes were centrifuged for $20 \mathrm{~h}$ at $60,000 \mathrm{rpm}$ at $20^{\circ} \mathrm{C}$ in a Beckman Ultracentrifuge L5-65, 70Ti-Rotor.

The band containing plasmid DNA was recovered with syringe and needle. The ethidium bromide was extracted from the DNA solution several times with equal volumes of isoamylalcohol until the solution was colorless.

The clear solution was put into dialysis tubings and dialysed against $1 \mathrm{~L}$ TE per construct (10 $\mathrm{mM}$ Tris $\mathrm{pH} 8.0,1 \mathrm{mM}$ EDTA $\mathrm{pH} 8.0$ ) twice at $4^{\circ} \mathrm{C}$ to remove $\mathrm{CsCl}$.

Alternatively the JestStar kit was used for maxi preparation of plasmid DNA.

The concentration and purity of the plasmid DNA was estimated spectrophotometrically (OD260, OD280 in Shimadzu Spectrophotometer). 


\section{2. 1.5 Measurement of DNA concentration}

DNA concentration was estimated using the spectrophotometer. The concentration of DNA is calculated as following :

for double-stranded DNA : $\quad 1.0 \mathrm{OD}_{260}$ unit corresponds to $50 \mu \mathrm{g} / \mathrm{ml}$

In addition to $\mathrm{OD}_{260}$, also the absorption at $280 \mathrm{~nm}$ was measured indicating protein concentration. DNA or RNA preparations which had ratio of $\mathrm{OD}_{260} / \mathrm{OD}_{280}$ in the range of 1.8 - 2.0 were regarded as pure and protein-free.

\section{2. 1. 6 Restriction enzyme analysis of DNA}

In order to characterize plasmid DNA, it was digested with restriction endonucleases. Digestions were carried out for $2 \mathrm{~h}$ in $20 \mu \mathrm{l}$ total volume in the optimal buffer for each enzyme, as suggested by Fermentas. The digestion temperature was $37^{\circ} \mathrm{C}$, unless otherwise suggested. Double digestions were also performed. In this case the buffer was determined by a compatibility table provided by Fermentas.

\section{2.1.7 Agarose gel electrophoresis}

During agarose gel electrophoresis, DNA fragments are separated according to their size e.g. the smaller a fragment, the faster it migrates. The size of a fragment is estimated by comparison to the sizes of the bands of a DNA molecular weight marker. Agarose in an appropriate concentration was dissolved in $1 \mathrm{x}$ TAE in a microwave oven. The solution was cooled and ethidium bromide was added at a final concentration $1 \mu \mathrm{g} / \mathrm{ml}$. The solution was poured into a gel chamber with a well separator and let to solidify at room temperature. The concentration of the gel determines the optimal separation of DNA fragments different in size e.g. large fragments separate in low concentration gels where small fragments in high agarose concentration (see the table below). DNA samples were mixed with $1 / 10$ volume of $10 \mathrm{x}$ loading buffer and loaded into the wells of the gel. Gels were electrophoresed at $80-$ $120 \mathrm{~V}$ for $1 \mathrm{~h}$ in a horizontal apparatus (Biorad, Munich) in $1 \mathrm{x}$ TAE buffer. After electrophoresis, DNA fragments based on their binding to ethidium bromide were visualized under UV transiluminator (254 or $366 \mathrm{~nm}$ ) (Vetter, Wiesloch) and photographed. Analyis was performed using a camera and software set (E.A.S.Y., Wiesloch).

\begin{tabular}{|c|c|}
\hline Percentage of agarose & DNA fragments separated \\
\hline $0.3 \%$ & $60-5 \mathrm{~kb}$ \\
\hline $0.6 \%$ & $20-1 \mathrm{~kb}$ \\
\hline $0.7 \%$ & $10-0.8 \mathrm{~kb}$ \\
\hline
\end{tabular}




\begin{tabular}{|c|c|}
\hline $0.9 \%$ & $7-0.5 \mathrm{~kb}$ \\
\hline $1.2 \%$ & $6-0.4 \mathrm{~kb}$ \\
\hline $1.5 \%$ & $4-0.2 \mathrm{~kb}$ \\
\hline $2.0 \%$ & $3-0.1 \mathrm{~kb}$ \\
\hline
\end{tabular}

(Sambrook et al., 1989)

\section{2. 1.8 Purification of DNA from agarose gel}

DNA fragments were purified after agarose gel electrophoresis using Easy Pure DNA purification kit (Biozym, Oldendorf). This process allows DNA fragments, separated electrophoretically, to be purified from other DNA fragments, salts or unincorporated nucleotides prior to cloning. After electrophoresis DNA fragments were excised from the agarose gel with sterile scalpel (band was visualized by UV transiluminator), transferred to sterile Eppendorf tube and mixed with $3 \times$ volumes of Salt buffer to dialyse the agarose. Samples were incubated for $5 \mathrm{~min}$ at $55^{\circ} \mathrm{C}$ and vortexed at various intervals. Next, depending on the expected amount of DNA the buffer Bind was added and incubated at RT for 5 min under constant agitation. The mixture was centrifuged for $5 \mathrm{sec}$ and the supernatant was discarded. The pellet was carefully resuspended in $1 \mathrm{ml}$ Wash buffer. Again the mixture was centrifuged for $5 \mathrm{sec}$ and supernatant was aspirated. The pellet was let to dry and was dissolved in $20 \mu \mathrm{l}$ TE buffer and incubated for $5 \mathrm{~min}$ at RT. After $1 \mathrm{~min}$ centrifugation step the DNA-containing supernatant was transferred to a fresh Eppendorf tube and stored at $4{ }^{\circ} \mathrm{C}$.

\section{2. 1.9 Blunt-end cloning}

Due to lack of any available sites to permit "sticky-end" cloning the constructs GSK3 $\beta w t$ and GSK3ßR85 were cloned in expression vectors by "blunt-end" cloning. This approach is technically more difficult since adhesion of the two ends before ligation is not stable because they do not hybridise with each other. The technique is applied for the ligation of two ends that have been digested either with blunt-end endonucleases or with sticky-end endonucleases and have been blunt-ended subsequently before the ligation step. It is usually used when no compatible restriction sites are available in the area of interest. Plasmids ratGSK-pXT7 and ratGSK/R85-pXT7 (obtained from Dr. I. Dominquez, Boston, USA) were digested with KpnI / SpeI and electrophoresed on an agarose gel. Inserts containing full length GSK3 cDNA were extracted and purified and then blunt-ended with Klenow fill in reaction in order to be cloned into the EcoRV site of the CMV-driven eukaryotic expression vector pBAT14 (obtained from Dr. M. German, San Francisco, USA). The blunt-end reaction was carried out at $37^{\circ} \mathrm{C}$ for $30 \mathrm{~min}$. Blunt-end synthesis is the result of the elongation of DNA strands at their 3' end, by Klenow polymerase, eliminating the overhangs created by restriction digestion. DNA fragments after purification were further processed for ligation. 
Klenow fill-in reaction:

eluted DNA fragments $\quad 23.5 \mu 1$

$10 \mathrm{mM}$ DNTPs $\quad 1.5 \mu \mathrm{l}$

$10 \mathrm{x}$ buffer (for Klenow polymerase, Fermentas) $\quad 3 \mu \mathrm{l}$

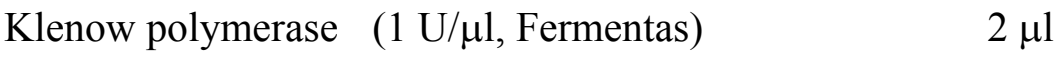

\section{2. 1. 10 Dephosphorylation of 5' protruding DNA ends}

In order to prevent vector religation in the cloning process, 5' phosphate groups were eliminated by treating digested pBAT14 with $1 \mu \mathrm{l}$ of alkaline phosphatase (Fermentas) at $37^{\circ} \mathrm{C}$ for $30 \mathrm{~min}$. At the end of the incubation time, SDS was added and EDTA pH 8.0 to final concentrations of $0.5 \%$ and $5 \mathrm{mM}$ respectively as well as proteinase $\mathrm{K}$ at $100 \mu \mathrm{g} / \mathrm{ml}$ to inactivate the enzyme. The mixture was incubated for $30 \mathrm{~min}$ at $56^{\circ} \mathrm{C}$. The dephosphorylated DNA was purified by extraction with phenol/chloroform.

\section{2.1.11 Ligation}

DNA ends of different fragments were ligated by incubation with T4 DNA-ligase (Fermentas) at $15^{\circ} \mathrm{C}$ overnight. Ligation is the formation of a covalent bond between a 5' phosphate and a 3' hydroxyl group. Ligation reaction mixture included 10-100 ng of vector and 5-10 times more insert DNA in molar quantities. Reaction was carried out in $20 \mu 1$ volume, using $1 \mu$ of T4 DNA-ligase in $1 \mathrm{x}$ ligation buffer (including ATP) (Fermentas).

Constructs were sequenced by enzymatic cycle sequencing to confirm identity and orientation of the inserts.

\subsubsection{DNA Sequencing}

\section{Sequencing reaction}

Sequencing was performed with the Thermo Sequenase Fluorescent Labelled Primer Cycle Sequencing kit (Amersham-Pharmacia, Braunschweig). This kit combines conventional dideoxy sequencing reactions (Sanger method) with thermal cycling conditions to generate high quality sequences from very small amounts of template DNA. The use of thermostable Taq DNA polymerase makes it possible to repeatedly cycle the template through alternate periods of heat denaturation, annealing and extension at elevated temperatures. Under these conditions the purity and quantity of starting template are less critical. The elevated temperatures inhibit reannealing of linear double-stranded DNA templates, such as PCR products, thus improving the effective amount of template available for reaction. Fluorescent labelled sequencing primers allow to read the sequence using laser scanner. Typically $4 \mu 1$ reaction contained : 
plasmid DNA (40-80 ng/ $\mu \mathrm{l})$

sequencing primer $(1 \mathrm{pmol} / \mu \mathrm{l})$

$\mathrm{A} / \mathrm{C} / \mathrm{G} / \mathrm{T}$ reagent (Amersham)
$2.5 \mu 1$

$0.5 \mu 1$

$1 \mu 1$ (different in each reaction)

Components were pipetted on ice into "thin-walled PCR tubes" (Boerhinger, Mannheim) and overlayed with mineral oil (Sigma, Munich). The reaction took place in Biometra TRIOThermoblock according to following PCR temperature profiles :

\begin{tabular}{|l|l|l|l|}
\hline Primer & Denaturation & Temperature profile & Cycles \\
\hline CMV promoter & $95^{\circ} \mathrm{C} / 5 \mathrm{~min}$ & $95^{\circ} \mathrm{C} / 30 \mathrm{sec} 57^{\circ} \mathrm{C} / 20 \mathrm{sec} 70^{\circ} \mathrm{C} / 45 \mathrm{sec}$ & 30 \\
\hline
\end{tabular}

Samples of the sequencing reaction were mixed with $1 \mu$ of sequencing stop buffer (Amersham-Pharmacia, Braunschweig) and denatured for $3 \mathrm{~min}$ before loading on the sequencing polyacrylamide gel.

5'-end fluorescently labelled with IRD800 (MWG-Biotech, Ebersberg)

CMV promoter : $\quad$ 5'-CAGAGCTCGTTTAGTGAACC-3'

\section{Sequencing polyacrylamide gel electrophoresis}

To separate DNA fragments with very small molecular weight differences (single nucleotide) as it is required in sequencing, a denaturing polyacrylamide gel electrophoresis was used with urea as a denaturing agent. The gel was prepared using SequaGel XR-Acrylamide kit (Biozym, Hess.Oldendorf) in total volume of $40 \mathrm{ml}$ :

SequaGel XR-Acrylamide solution

SequaGel complete buffer reagent

DMSO

APS $(10 \%)$
$32 \mathrm{ml}$

$8 \mathrm{ml}$

$400 \mu 1$

$300 \mu 1$

After addition of APS the gel mix was poured into a casting frame (Biozym) with $0.25 \mathrm{~mm}$ spacer thickness and allowed to polymerize for ca. $2 \mathrm{~h}$ at RT. After polymerization the gel was fixed onto sequencing apparatus (Li-Cor 4000, MWG-Biotech, Ebersberg) and pre-run for $30 \mathrm{~min}(1,500 \mathrm{~V})$ to achieve the denaturing temperature $\left(50^{\circ} \mathrm{C}\right) .4 \mu \mathrm{l}$ of the sequencing reaction with $1 \mu$ of the loading buffer (USB/Amersham, Braunschweig) were denatured $\left(95^{\circ} \mathrm{C}, 3 \mathrm{~min}\right)$ and directly loaded into the gel. Electrophoresis was run in $1 \mathrm{x}$ TBE buffer under $1,500 \mathrm{~V}$ for ca. $16 \mathrm{~h}$. The sequences were automatically scanned by sequencing laser. Reading of sequence was done by software attached to the sequencer (Data Collection, LiCor Inc., Lincoln, USA). The sequences were further analyzed through the GCG software package or other internet available sources e.g. NCBI. 


\section{2. 2 GST-recombinant protein expression and purification in bacteria}

DH5a E.coli cells were transformed with GST-based vectors as usually. In order to identify which of the colonies express in high amounts the recombinant protein, several colonies are chosen and inoculated overnight at $37^{\circ} \mathrm{C}$ in $3 \mathrm{ml} \mathrm{LB}$ plus amp.

Next day $100 \mu \mathrm{l}$ of the pre-cultures were used to inoculate $3 \mathrm{ml} \mathrm{LB}$ plus amp. These cultures were this time induced with IPTG (dissolved in water) to final concentration of $1 \mathrm{mM}$. After IPTG induction culture was further grown for additional $3-4 \mathrm{~h}$ at $37^{\circ} \mathrm{C}, 220 \mathrm{rpm}$. The bacteria were centrifuged at 3,000 rpm for $10 \mathrm{~min}$ at RT. The pellet was dissolved in $1 \mathrm{x}$ SDS sample buffer, loaded on a protein gel (10\%) and stained with Coomassie.

Once a colony that expressed the recombinant protein at high levels was identified then it was used to inoculate a pre-culture of $20 \mathrm{ml} \mathrm{LB}$ plus amp $\mathrm{ON}$ at $37^{\circ} \mathrm{C}, 220 \mathrm{rpm}$.

The $20 \mathrm{ml}$ pre-culture was further used to inoculate $1 \mathrm{~L} \mathrm{LB}$ plus amp and was grown approximately $3 \mathrm{~h}$ until O.D.600 reached 0.6. Reference sample (non-induced) of $1 \mathrm{ml}$ was taken and culture was induced with IPTG to final concentration of $1 \mathrm{mM}$ for additional 3-4 h at $37^{\circ} \mathrm{C}, 220 \mathrm{rpm}$.

Culture was centrifuged to harvest bacteria for $15 \mathrm{~min}, 3,500 \mathrm{rpm}$ at $4^{\circ} \mathrm{C}$ and pellet was resuspended in ice-cold $15 \mathrm{ml} 1 \mathrm{x}$ PBS with $1 \mathrm{mM}$ DTT and $1 \mathrm{mM}$ PMSF (in $50 \mathrm{ml}$ Bluecap). Suspension was frozen with $\mathrm{N}_{2}$ and stored $\mathrm{ON}$ at $-80^{\circ} \mathrm{C}$.

Frozen bacteria suspension was slowly thawed on ice-water bath for ca. $3 \mathrm{~h}$ and sonicated $6 \mathrm{x}$ $45 \mathrm{sec}$ pulses of 400 Watt with 1 min intervals between pulses (during the whole process the bacteria must remain in ice-water to avoid sample overheating).

To homogenate NP-40 detergent was added to final concentration of $0.1 \%$ and sample was agitated at rocking platform for $30 \mathrm{~min}$ at $\mathrm{RT}$.

Lysate was centrifuged for $10 \mathrm{~min}$ at $10,000 \mathrm{rpm}$ at $4^{\circ} \mathrm{C}$. Supernatant was taken and $1 \mathrm{ml}$ of the pre-hydrated Glutathione Agarose Slurry was added (in 50ml Bluecap). DTT was added to final concentration of $5 \mathrm{mM}$.

Suspension was agitated at rocking platform for $1-2 \mathrm{~h}$ at $4^{\circ} \mathrm{C}$ slowly and then suspension was centrifuged for $5 \mathrm{~min}$ at 2,000 rpm at RT (the supernatant was collected and stored at $4^{\circ} \mathrm{C}$ in case the protein was not bound on the beads).

Pellet of agarose beads was transferred in $2 \mathrm{ml}$ Eppendorf tube and washed four times with $1.5 \mathrm{ml}$ PBS containing $1 \mathrm{mM}$ DTT and $1 \mathrm{mM}$ PMSF. Centrifugation step during washing steps consisted of $2 \mathrm{~min} 2,000 \mathrm{rpm}$ at RT. At each washing step, $500 \mu 1$ reference sample was taken from the supernatant.

The beads were eluted $5 \times 600 \mu$ of Elution buffer (for each $500 \mu \mathrm{l}$ of beads) at RT, $10 \mathrm{~min}$ at $750 \mathrm{rpm}$ in Eppendorf-thermomixer (centrifuge $2 \mathrm{~min} 2,000 \mathrm{rpm}$ at RT). The eluates and the beads are stored at $4{ }^{\circ} \mathrm{C}$ (volume of each approx. $600 \mu \mathrm{l}$ ).

All reference samples together with the eluates and the beads were mixed with $2 \times$ SDS sample buffer, heated at $95^{\circ} \mathrm{C}$ and loaded on a protein gel.

If there was enough of the correct size of the recombinant protein in the eluates, then these fractions were placed in dialysis tubing (GIBCO BRL, Karlsruhe) and dialysed twice against 1-2 L of Dignam D buffer ON at $4^{\circ} \mathrm{C}$. 
After the dialysis of the protein, concentration was estimated using standard Bradford reagents. Protein samples were stored at $-80^{\circ} \mathrm{C}$.

This protocol was used to express and purify the proteins GST-Pax6TAD (aa 299-437 from the transactivation domain of Pax6 zebrafish, Mikkola et al., 1999) and GST-CBP (aa 20402305 from murine CBP, research group Prof.Knepel).

Suspension buffer : PBS plus $1 \mathrm{mM}$ DTT plus $1 \mathrm{mM}$ PMSF

Elution buffer $(10-20 \mathrm{ml})$ :

$50 \mathrm{mM}$ glutathione in $50 \mathrm{mM}$ Tris $\mathrm{pH} 7.4$

(adjust the $\mathrm{pH}$ between 7.0 and 7.5 after addition of glutathione)

Dialysis buffer :

$\begin{array}{lr}\text { Tris pH 7.4 } & 20 \mathrm{mM} \\ \text { NaCl } & 100 \mathrm{mM} \\ \text { EDTA } & 0.2 \mathrm{mM} \\ \text { DTT } & 0.5 \mathrm{mM} \\ \text { PMSF } & 0.5 \mathrm{mM}\end{array}$

Glutathione Agarose Slurry :

$80 \mathrm{mg}$ of Glutathione Agarose was suspended in $1 \mathrm{ml} \mathrm{PBS}$ to hydrate (ON at $4^{\circ} \mathrm{C} 750 \mathrm{rpm}$ ) and then agarose was washed four times with $1 \mathrm{ml}$ PBS and resuspended in $1 \mathrm{ml}$ PBS plus 1 $\mathrm{mM}$ DTT plus $1 \mathrm{mM}$ PMSF and stored at $4^{\circ} \mathrm{C}$.

\section{2. 3 Affinity purification of GSK3 from InR1G9 cells (in collaboration with Prof. Meijer's laboratory, Roscoff, France)}

Axin-His6 was purified by affinity chromatography, after expression in bacteria, on NickelNTA agarose. The Ni-NTA-bound Axin-His6 could then be used as an affinity reagent for GSK3 purification. $30 \mu \mathrm{l}$ of the beads were mixed with $250 \mu \mathrm{g}$ of proteins from InR1G9 cellular extracts in homogenization buffer. The mixture was rotated at $200 \mathrm{rpm}$ for $30 \mathrm{~min}$ at $4^{\circ} \mathrm{C}$. After a $10 \mathrm{sec}$ pulse centrifugation, the supernatant was eliminated. The GSK3 / AxinHis6-Ni-NTA beads were washed four times with $200 \mu$ l homogenization buffer and four times with K-buffer $200 \mu$ l. GSK3 / Axin-His6 was then eluted from the beads by adding 100 $\mu \mathrm{l}$ of K-buffer containing $200 \mathrm{mM}$ imidazole. The mixture was rotated at $200 \mathrm{rpm}$ at RT for $2 \mathrm{~min}$. After a $10 \mathrm{sec}$ centrifugation, the supernatant was recovered and frozen at $-80^{\circ} \mathrm{C}$.

Homogenization buffer:

$\beta$-glycerophosphate $\quad 60 \mathrm{mM}$

p-NPP $\quad 15 \mathrm{mM}$ 


$\begin{array}{lr}\text { MOPS pH 7.2 } & 25 \mathrm{mM} \\ \mathrm{MgCl}_{2} & 15 \mathrm{mM} \\ \text { DTT } & 0.5 \mathrm{mM} \\ \text { Na-vanadate } & 1 \mathrm{mM} \\ \mathrm{NaF} & 1 \mathrm{mM} \\ \text { diNa-phenylphosphate } & 1 \mathrm{mM} \\ \text { Leupeptin } & 10 \mu \mathrm{g} / \mathrm{ml} \\ \text { Aprotinin } & 10 \mu \mathrm{g} / \mathrm{ml} \\ \text { SBTI } & 10 \mu \mathrm{g} / \mathrm{ml} \\ \text { Benzamidine } & 100 \mu \mathrm{M}\end{array}$

K-buffer :

$\begin{array}{lr}\mathrm{MgCl}_{2} & 30 \mathrm{mM} \\ \text { EGTA } & 3 \mathrm{mM} \\ \text { DTT } & 3 \mathrm{mM} \\ \text { Tris pH } 7.5 & 75 \mathrm{mM} \\ \text { Heparin } & 150 \mu \mathrm{g} / \mathrm{ml}\end{array}$

\section{2. 4 SDS-polyacrylamide gel electrophoresis}

Analytical SDS gel electrophoresis of proteins is carried out in polyacrylamide gels under conditions that ensure dissociation of the proteins into their individual polypeptide subunits and that minimize aggregation. The strongly anionic detergent SDS is used in combination with a reducing agent ( $\beta$-mercaptoethanol) and heat to dissociate the proteins before they are loaded onto the gel. The denatured polypeptides bind SDS and become negatively charged. Because the amount of SDS bound is almost always proportional to the molecular weight of the polypeptide and is independent of its sequence, SDS-polypeptide complexes migrate through polyacrylamide gels in accordance with the size of the polypeptide. By using markers of known molecular weight it is therefore possible to estimate the molecular weight of the polypeptide chain.

In most cases, SDS-polyacrylamide gel electrophoresis is carried out with a discontinuous buffer system in which the buffer in the reservoirs is of a different $\mathrm{pH}$ and ionic strength from the buffer is used to cast the gel. After migrating through a stacking gel of high porosity, the complexes are deposited in a very thin zone on the surface of the resolving gel. The ability of discontinuous buffer systems to concentrate all of the complexes in the sample into a very small volume greatly increases the resolution of SDS-polyacrylamide gels.

The sample and the stacking gel contain Tris ( $\mathrm{pH}$ 6.8), the upper and the lower buffer reservoirs contain Tris-glycine $(\mathrm{pH} \mathrm{8.3)}$ and the resolving gel contains Tris $(\mathrm{pH} \mathrm{8.8).} \mathrm{All}$ components of the system contain $0.1 \%$ SDS. In this study $4 \%$ stacking gel and $10 \%$ resolving gel were prepared and electrophoresis was run in Mighty Small-System apparatus, SE 250 (Hoefer, San Francisco) in 1 x Tank buffer at constant current of $20 \mathrm{~mA}$. 
Before loading the protein samples were mixed with loading buffer and denatured by incubation for $5 \mathrm{~min}$ at $95^{\circ} \mathrm{C}$. After electrophoresis the gel was stained with Coomassie-Blue Solution for $30 \mathrm{~min}$ at RT. Destaining was done by incubating in destaining solution for $4 \mathrm{~h}$ changing the solution 3-4 times.

$10 \%$ Resolving Gel :

Acrylamide Mix

$3.33 \mathrm{ml}$

Resolving Buffer (1.5 mM Tris pH 8.8)

$2.5 \mathrm{ml}$

Water

$4 \mathrm{ml}$

$10 \%$ SDS

$100 \mu 1$

$10 \% \operatorname{APS}(0.1 \mathrm{~g} / 1 \mathrm{ml}$ in water $)$

$100 \mu \mathrm{l}$

TEMED

$6 \mu 1$

4\% Stacking Gel :

Acrylamide Mix

$0.67 \mathrm{ml}$

Stacking Buffer (0.5 M Tris pH 6.8) $\quad 1.25 \mathrm{ml}$

Water

$3 \mathrm{ml}$

$10 \%$ SDS

$50 \mu 1$

$10 \%$ APS $(0.1 \mathrm{~g} / 1 \mathrm{ml}$ in water $)$

$50 \mu 1$

TEMED

$2.4 \mu 1$

Acrylamide Mix :

Acrylamide

$29.2 \mathrm{~g}$

Bisacrylamide

$0.8 \mathrm{~g}$

Water

$100 \mathrm{ml}$

Loading Buffer $(2 \mathrm{x})$ :

Tris $\mathrm{pH} 6.8$

$125 \mathrm{mM}$

Bromophenolblue

$1 \mathrm{mg} / 1 \mathrm{ml}$

SDS

$4 \%$

Glycerol

$20 \%$

$\beta$-mercaptoethanol

$10 \%$

Staining solution (per $100 \mathrm{ml}$ ):

Methanol

$45 \mathrm{ml}$

Water

$45 \mathrm{ml}$

Acetic acid

$10 \mathrm{ml}$

plus 0.25 g Coomassie blue R250 (Sigma, B-0149)

Destaining solution (per $100 \mathrm{ml}$ ) :

Methanol

Water

$45 \mathrm{ml}$

Acetic acid

$10 \mathrm{ml}$ 
Tank buffer $(5 \mathrm{x})$ :

Tris $\mathrm{pH} 8.3$

Glycine

SDS
$25 \mathrm{mM}$

$192 \mathrm{mM}$

$0.1 \%$

\section{2.5 Western Blot Analysis}

In western blotting electrophoretically separated components are transferred from a gel to a solid support and probed with antibodies that react specifically with antigenic epitopes displayed by the target protein attached to the solid support. In western blotting, the samples to be assayed are solubilized with detergents and reducing agents, separated by SDSpolyacrylamide gel electrophoresis and transferred to a solid surface such as a nitrocellulose filter. The filter is subsequently exposed to unlabeled antibodies specific for the target protein. Finally, the bound antibody is detected by one of several secondary immunological reagents. As little as $1-5 \mathrm{ng}$ of an average-sized protein can be detected by western blotting.

The following protocol was used :

Almost fully confluent InR1G9 cells were splitted the day before the insulin or the GSK3 inhibitors treatment and plated out in complete medium. 3-4 hrs before the treatment medium was withdrawn and fresh medium containing BSA and antibiotics was applied. Again medium was replaced by fresh medium containing BSA and antibiotics and cells were treated either with insulin or with GSK3 inhibitors at the indicated concentrations and time point intervals. Then, cells were first washed in $2 \mathrm{ml}$ ice-cold PBS and then scraped in $1 \mathrm{ml}$ icecold PBS. The mixture was centrifuged at $1,000 \mathrm{rpm}$ for $5 \mathrm{~min}$ at $4^{\circ} \mathrm{C}$ and the supernatant was aspirated. The pellet was dissolved in $100 \mu \mathrm{l}$ lysis buffer and left on ice for $20 \mathrm{~min}$. Next it was centrifuged at high speed, $14,000 \mathrm{rpm}$, for $15 \mathrm{~min}$ at $4^{\circ} \mathrm{C}$ and the supernatant, containing the lysate, was transferred to a fresh Eppendorf tube. The lysates $(15 \mu \mathrm{l}$ of total extracts) were separated by SDS-PAGE (2.2.4) and the proteins were subjected to western blotting.

The SDS gel was incubated for $20 \mathrm{~min}$ in Buffer C. During this time membrane used for blotting (Hybond-ECL ${ }^{\mathrm{TM}}$, Nitrocellulose, Amersham) was incubated for few seconds in water and then was immersed for 15 min in Buffer B.

Proteins were electroblotted from the gel to the membrane using dry electroblotting apparatus (Scientific Equipment Workshop, Clinics of Göttingen University ) under constant current of $70 \mathrm{~mA}$ for $1.5 \mathrm{~h}$. The arrangement of blotting stack was as following : (from "+" - bottom to "_“ - top electrode) $2 \mathrm{x}$ whattman paper in Buffer A, $2 \mathrm{x}$ whattman paper in Buffer B, membrane in Buffer B, gel in Buffer C, $4 \mathrm{x}$ whattman paper in Buffer $\mathrm{C}$.

After electroblotting the membrane was blocked (unspecific protein binding) by incubation for $1 \mathrm{~h}$ at RT in Blocking solution. Membrane was then washed three times in TBS-T buffer for 15 min at RT (Mini Rocking Platform). 
Primary antibody (1:1000 for phospho-GSK $3 \alpha / \beta, 1 \mu \mathrm{g} / \mathrm{ml}$ for unphosphorylatedGSK $3 \alpha / \beta$, 1:500 for $\beta$-catenin) in blocking solution was applied to membrane and incubated overnight at $4^{\circ} \mathrm{C}$ under constant shaking $\mathrm{ON}$.

Membrane was then washed three times in TBS-T buffer for $15 \mathrm{~min}$ at RT always on the shaking platform. Membrane was incubated with secondary antibody (depending on the source of the primary antibody), which was diluted in blocking buffer (1:2000) and incubated for $1 \mathrm{~h}$ at RT. Membrane was then washed three times with TBS-T buffer for $15 \mathrm{~min}$ at RT.

The blot was visualised using ECL Western Blotting System - Amersham Pharmacia, Vienna (HRP-catalysed chemiluminescence detection). Shortly, the membrane was incubated for $1 \mathrm{~min}$ in $5 \mathrm{ml}$ of developing mixture (2.5 ml of Solution A and $2.5 \mathrm{ml}$ of Solution B) and then was wrapped in saran foil and exposed to Röntgen films (Hyperfilm MP, Amersham, Braunschweig) for time intervals ranging from 0.5 to 5 min in Röntgen cassettes (Kodak XOmatic) at RT and were subject to autoradiography. The films were developed by incubating ca. $15 \mathrm{sec}$ in developer solution (LX 24, Kodak) then short wash in water and incubation in fixer solution ca. $15 \mathrm{sec}$ (AL 4, Kodak). After final wash in water the film was air-dried.

Lysis buffer :

Tris $\mathrm{pH} 7.4$

$25 \mathrm{mM}$

$\mathrm{NaF}$

$50 \mathrm{mM}$

EDTA

$3 \mathrm{mM}$

EGTA

$3 \mathrm{mM}$

Sucrose

$0.27 \mathrm{M}$

Sodium orthovanadate

$2 \mathrm{mM}$

Sodium $\beta$-glycerophosphate

$10 \mathrm{mM}$

Sodium pyrophosphate

$5 \mathrm{mM}$

Triton X-100

$0.5 \%$

$\beta$-mercaptoethanol

$0.1 \%$

plus protease inhibitors

PMSF

$1 \mathrm{mM}$

Leupeptin

$1 \mu \mathrm{g} / \mathrm{ml}$

Pepstatin

$1 \mu \mathrm{g} / \mathrm{ml}$

Okadaic acid

$400 \mathrm{nM}$

- $\mathrm{pH}$ was adjusted to 7.4 with $5 \mathrm{~N} \mathrm{HCl}$ and the buffer was sterilised by filtration $(0.2 \mu \mathrm{m})$

Buffer A (approx. pH 11.3) :

Tris

$300 \mathrm{mM}$

Methanol

$$
20 \%(\mathrm{v} / \mathrm{v})
$$

Buffer B (approx. pH 10.5):

Tris

$25 \mathrm{mM}$

Methanol

$20 \%$ (v/v) 
Buffer $\mathrm{C}$ (adjust $\mathrm{pH}$ at 9.0 with borate acid) :

$\begin{array}{lr}\text { Tris } & 25 \mathrm{mM} \\ \text { Methanol } & 20 \%(\mathrm{v} / \mathrm{v})\end{array}$

Blocking Solution : TBS-T buffer with 5\% (w/v) Skim Milk Powder (Fluka, \#70166)

TBS-T buffer :

Tris $\mathrm{pH} 8.0$

$\mathrm{NaCl}$

Tween-20

$$
10 \mathrm{mM}
$$$$
150 \mathrm{mM}
$$

$0.1 \%(\mathrm{v} / \mathrm{v})$

\section{2. 6 Phosphorylation of GST-fusion proteins by recombinant GSK3 $\beta$ in vitro}

GST-fusion proteins (GST-Pax6 (TAD), GST-CBP aa 2040-2305) were purified as in 2.2.2. In the absence of any knowledge concerning which might be the priming kinase (most of the GSK3 substrates need a priming phosphorylation to enable GSK3 to phosphorylate them efficiently) the GST-fusion proteins ( $3 \mu \mathrm{g}$ each) were pre-incubated with whole cell extracts. The reaction mixture contained, in addition to the GST-fusion proteins, $30 \mu \mathrm{g}$ of cell extracts (prepared as described in 2.2.5) in lysis buffer, plus $1 \mathrm{mM}$ ATP (non-radioactively labelled) in reaction buffer, plus $30 \mu \mathrm{l}$ of prehydrated agarose slurry (dissolved in $1 \mathrm{x}$ reaction buffer). It was incubated for $45 \mathrm{~min}$ at $30^{\circ} \mathrm{C}$, under constant agitation $750 \mathrm{rpm}$ in Eppendorf thermomixer. Then the mixture was extensively washed (at least five times) in $200 \mu 1$ reaction buffer without ATP to remove the cell lysates (centrifugation steps during washing 2 min at 2,000 rpm at RT). Next, active recombinant GSK3 $\beta$ (50 mU per assay, Upstate Biotechnoloy) was added to the beads in the presence of $1 \mathrm{mM}$ ATP plus $5 \mu \mathrm{Ci}$ radioactively labelled $\gamma-{ }^{32} \mathrm{P}$-ATP. The mixture was incubated at $30^{\circ} \mathrm{C}$ for $30 \mathrm{~min}$ in Eppendorf thermomixer at $750 \mathrm{rpm}$. It was then centrifuged at 10,000 rpm at RT for 2 min and the supernatant containing the radioactivity was carefully discarded. Beads were washed $2 \mathrm{x}$ in $200 \mu \mathrm{l}$ reaction buffer and finally they were dissolved in $15 \mu 12 \times$ SDS buffer and incubated for $5 \mathrm{~min}$ in an Eppendorf thermomixer at $95^{\circ} \mathrm{C}$ (this step released the GST-fusion protein from the beads). The mixture was centrifuged at 10,000 rpm at RT for 2 min and then $15 \mu 1$ of the supernatant were loaded on a $10 \%$ SDS-PAGE gel (the pellet contained the beads). After electrophoresis, the gel was stained with Coomassie for $30 \mathrm{~min}$ and destained ON. Next day, the gel was dried under vacuum and placed over a phosphorimager screen in a cassette for 1-2 days. The screen was scanned using phophorimager reader (Fujix BAS 1500, Raytest, Straubenhardt) and data were subject to software analysis by TINA DATA Reader.

prephosphorylation mixture :

$\begin{array}{ll}\text { GST-fusion protein }(3 \mu \mathrm{g}) & 10 \mu \mathrm{l} \\ \text { cell lysates }(30 \mu \mathrm{g} \text { in cell lysis buffer }) & 10 \mu \mathrm{l} \\ \text { ATP }(1 \mathrm{mM} \text { in } 1 \text { x Reaction buffer }) & 10 \mu \mathrm{l}\end{array}$


"hot" reaction mixture:

(the beads contain already the GST-fusion proteins from the prephosphorylation mixture and then you add)

GSK3 $\beta$ (50 mU of the enzyme in $1 \times$ Reaction buffer) $\quad 10 \mu 1$

ATP $\left(1 \mathrm{mM}\right.$ in $1 \mathrm{x}$ Reaction buffer plus $5 \mu \mathrm{Ci}, \gamma$ - $\left.{ }^{32} \mathrm{P}-\mathrm{ATP}\right) \quad 10 \mu \mathrm{l}$

\section{Reaction buffer $(1 \mathrm{x})$ :}

Tris $\mathrm{pH} 7.5$

$\mathrm{MgCl}_{2}$

DTT

$$
\begin{array}{r}
50 \mathrm{mM} \\
10 \mathrm{mM} \\
5 \mathrm{mM}
\end{array}
$$

Cell lysis buffer (see 2. 2. 5)

\section{2. 7 GSK3 activity measured by ex vivo assay}

InR1G9 cells were plated with complete medium in $6 \mathrm{~cm}$ dishes. Next day medium was replaced by the one containing only BSA and antibiotics and cells were treated with or without the indicated concentrations of various GSK3 inhibitors and insulin for $90 \mathrm{~min}$. Then, cells were washed in ice-cold PBS and lysed with lysis buffer (2.2.5). Lysates $(30 \mu \mathrm{g})$ were assayed for total GSK3 activity in a reaction containing a GSK3-peptide substrate or non-substrate control peptide. After $30 \mathrm{~min}$ incubation at $30^{\circ} \mathrm{C} 25 \mu \mathrm{l}$ of the reaction was spotted on the center of a $2 \mathrm{~cm} \mathrm{x} 2 \mathrm{~cm}$ Whatman P81 phosphocellulose paper (Whatman). After allowing the radiolabelled substrate to bind to the filter paper for $30 \mathrm{sec}$ the assay squares were immersed into a conical tube and washed wit $0.75 \%$ phosphoric acid twice, rinsed once with acetone, dried and counted by liquid scintillation spectrometry (Beckman LS 1801). Total lysate GSK3 activity is the amount of ${ }^{32} \mathrm{P}$-phosphate incorporated into the substrate peptide (prephosphorylated peptide, \#12-241, Upstate Biotechnology) minus that incorporated into the control peptide (\#12-242, Upstate Biotechnology). As a control pure GSK3 enzyme (Upstate Biotechnology) was used in the above experiment.

Assay protocol :

Reaction buffer $(1 \mathrm{x})$ per assay $\quad 10 \mu \mathrm{l}$

Substrate or control peptide $\quad 10 \mu \mathrm{l}$

GSK3 protein or lysates $\quad 10 \mu \mathrm{l}$

$\gamma$ - ${ }^{32}$ P-ATP $\quad 10 \mu 1$

Reaction buffer $(1 \mathrm{x})$ :

MOPS pH $7.4 \quad 8 \mathrm{mM}$

EDTA $\quad 0.2 \mathrm{mM}$

$\mathrm{MgCl}_{2} \quad 10 \mathrm{mM}$ 
- GSK3 substrate or control peptide was rehydrated in distilled water and used at a final concentration of $62.5 \mu \mathrm{M}$ per assay

- GSK3 enzyme was diluted in $1 \mathrm{x}$ reaction buffer (40 $\mathrm{mU}$ per assay) (control reaction)

- Lysates $(30 \mu \mathrm{g})$ were prepared as described in 2.2.5

- $\gamma^{-32} \mathrm{P}$-ATP (at a final concentration of $2.5 \mu \mathrm{Ci}$ per assay) was diluted in $1 \mathrm{x}$ reaction buffer containing $1 \mathrm{mM}$ unlabeled ATP

\section{2.8 Eukaryotic cell culture methods}

All experiments and treatments of cells were performed under sterile conditions using sterile hood (Heraeus, Hamburg). Solutions and media were sterilized either by autoclaving or by filtering and prewarmed before use $\left(37^{\circ} \mathrm{C}\right.$ water bath). All glassware items, such as pipettes and bottles were autoclaved before use, and rinsed with $70 \%$ isopropanol before entering the sterile hood.

\section{2. 8. 1 Cell culture}

InR1G9 cells were grown in $30 \mathrm{ml}$ of complete culture medium on $15-\mathrm{cm}$ plates in $5 \% \mathrm{CO}_{2}$, $97 \%$ humidity atmosphere $\left(37^{\circ} \mathrm{C}\right)$ in cell culture incubator (Steri-Kult incubator, Labotect $\mathrm{GmbH}$, Göttingen). Cells were grown to $80-90 \%$ confluency and then propagated as following: plates were washed with $15 \mathrm{ml} 1$ x PBS. Next $3 \mathrm{ml}$ of trypsin / EDTA were applied to detach the cells. After incubation for $2-3 \mathrm{~min}$ at $37^{\circ} \mathrm{C}$, plates were shaken and cells were washed off from the plate with $10 \mathrm{ml}$ of complete medium and transferred to $50 \mathrm{ml}$ tube (Blue Max, Falcon, Becton). The suspension was centrifuged for 2 min at 1,300 rpm at RT and the pellet was resuspended in $10 \mathrm{ml}$ complete medium and centrifuged again. Cells were resuspended in $30 \mathrm{ml}$ of complete medium in desired ration and suspension was plated out.

\section{2. 8. 2 DEAE-Dextran transfection}

Positively-charged DEAE-dextran forms complexes with negatively-charged DNA which then is taken up from the cells. This method was used to transfect the InR1G9 cells once they reached $80-90 \%$ confluency. The plate was washed with $15 \mathrm{ml}$ of $1 \mathrm{x}$ PBS, then $3 \mathrm{ml}$ of trypsin / EDTA was applied. After incubation for $2-3 \mathrm{~min}$ at $37^{\circ} \mathrm{C}$, the plate was shaken to detach the cells. The cells were washed off with medium containing no serum and transferred to $50 \mathrm{ml}$ tube as before. After centrifugation, the cell pellet was resuspended in $10 \mathrm{ml} \mathrm{TD}$ Buffer and centrifuged again (washing step). Cell pellet was then resuspended in TD Buffer in amount of $1 \mathrm{ml}$ TD per 6-cm plate. DEAE-dextran solution $(5 \mu 1$ per 6 -cm plate) was added to cell suspension and after gentle mixing it was transferred to $50 \mathrm{ml}$ tubes containing DNA to be transfected. After gentle mixing DNA / cell suspension was incubated for 15 min at RT to allow DNA uptake and then serum-containing culture medium $(1 \mathrm{ml}$ per $\mathrm{ml}$ of cell 
suspension) was added to stop transfection. Cells were centrifuged and washed with complete medium. After final centrifugation cells were suspended in culture medium $(5 \mathrm{ml}$ per 6-cm plate) and plated out. Cells were harvested $48 \mathrm{~h}$ after transfection and luciferase and GFP reporter gene assays were performed. As control for transfection efficiency and squelching pGFPtpz-cmv was co-transfected (500 ng per 6-cm plate) and total DNA content was kept constant throughout all groups in a given experiment by adding pBluescript.

\section{TD Buffer :}

$\begin{array}{lr}\text { Tris } \mathrm{pH} \mathrm{7.4} & 25 \mathrm{mM} \\ \mathrm{NaCl} & 140 \mathrm{mM} \\ \mathrm{KCl} & 5 \mathrm{mM} \\ \mathrm{K}_{2} \mathrm{HPO}_{4} & 0.7 \mathrm{mM}\end{array}$

DEAE-Dextran (M: 500,000): $60 \mathrm{mg} / \mathrm{ml}$ in distilled water and then sterilised by filtration

Insulin solution $(10 \mu \mathrm{M})$ :

Porcine insulin

$3 \mathrm{mg} / 50 \mathrm{ml}$

BSA

$100 \mathrm{mg} / 50 \mathrm{ml}$

Insulin was dissolved in $0.9 \% \mathrm{NaCl}$ solution ( $\mathrm{pH} 2.8$ ). The $\mathrm{pH}$ of the solution was neutralized by addition of $1 \mathrm{~N} \mathrm{NaOH}$ and then BSA was added. The aliquots of $1 \mathrm{ml}$ were stored at $80^{\circ} \mathrm{C}$.

\section{2. 8. 3 Insulin or GSK3 inhibitors treatment}

After transfection, the cells were incubated for $24 \mathrm{~h}$ in complete medium. Then the medium was withdrawn and fresh medium was applied containing BSA and antibiotics. $23 \mathrm{~h}$ before harvesting insulin was applied at a final concentration of $10 \mathrm{nM}$ or the GSK3 inhibitors (dissolved in DMSO, except lithium and valproic acid) at different concentrations.

\section{2. 8. 4 Cell extract preparation}

Cells were harvested $48 \mathrm{~h}$ after transfection. Plates were washed twice with 2-3 $\mathrm{ml}$ of icecold 1 x PBS buffer. $1 \mathrm{ml}$ of scraping buffer was then applied to each 6-cm plate. Cells were scraped with rubber scraper and the cell suspension was transferred to eppendorf tubes standing on ice. Each plate was rinsed with $0.5 \mathrm{ml}$ of scraping buffer and suspension was transferred to the same tube. Cells were centrifuged for $5 \mathrm{~min}$, at $6,000 \mathrm{rpm}, 4^{\circ} \mathrm{C}$ (Eppendorf $5415 \mathrm{C})$. The cell pellet was resuspended in $150 \mu \mathrm{l}$ of potassium phosphate buffer. Cells were then disrupted by three cycles of freezing and thawing (liquid nitrogen $/ 37^{\circ} \mathrm{C}$ water bath). The lysate was vortexed shortly and centrifuged $\left(5 \mathrm{~min}, 14,000 \mathrm{rpm}, 4^{\circ} \mathrm{C}\right)$. The cleared lysate was directly used for the luciferase or the GFP reporter gene assay. 
Scraping buffer :

$\begin{array}{lr}\text { Tris pH 7.5 } & 40 \mathrm{mM} \\ \mathrm{NaCl} & 150 \mathrm{mM} \\ \text { EDTA (pH 8.0) } & 1 \mathrm{mM}\end{array}$

Potassium Phosphate Buffer ( $\mathrm{pH} 7.8)$ :

$\begin{array}{ll}\mathrm{K}_{2} \mathrm{HPO}_{4} & 100 \mathrm{mM} \\ \mathrm{KH}_{2} \mathrm{PO}_{4} & 100 \mathrm{mM}\end{array}$

\section{2.8.5 Luciferase reporter gene assay}

Firefly luciferase enzyme catalyses oxydative decarboxylation of luciferin. This reaction is dependent on $\mathrm{Mg}^{2}$ ions and ATP and apart from AMP, $\mathrm{CO}_{2}$ and oxyluciferine, photons are produced. Light emission depends on the luciferase concentration, therefore luminometric measurement allows to estimate expression level of luciferase reporter gene. For the luciferase assay $50 \mu \mathrm{l}$ of cell extract was taken and mixed with $368 \mu$ of assay mix in luminometric tubes (Sarstedt, Nümbrecht). Tubes were vortexed and placed in a luminometer (AutoLumat LB 953, E\&G Berthold, Wildbach) where to each tube luciferine mix was injected and light emission in $560 \mathrm{~nm}$ was measured for $20 \mathrm{sec}$. One tube containing only luciferine mix served as reference sample to estimate background level.

Assay Mix :

Potassium Phosphate Buffer

$16.5 \mathrm{mM}$

Glycylglycine Buffer $82,4 \%(\mathrm{v} / \mathrm{v})$

DTT

$1 \mathrm{mM}$

ATP

$2 \mathrm{mM}$

Luciferine Mix in Glycylglycine Buffer:

Luciferine

$1 \mathrm{mM}$

DTT

$10 \mathrm{mM}$

Glycylglycine Buffer :

$\begin{array}{lr}\text { Glycylglycine }(\mathrm{pH} \mathrm{7.8)} & 25 \mathrm{mM} \\ \mathrm{MgSO}_{4} & 15 \mathrm{mM} \\ \text { EGTA } & 4 \mathrm{mM}\end{array}$




\section{2. 8. 6 GFP reporter gene assay}

The Green Fluorescent Protein (GFP) mutant (tpz) used in the assay is derived from jelly fish (Aequoria victoria). When irradiated with ultraviolet beam GFP protein possesses capability of emission of green light (fluorescent absorption/emission) which is proportional to its concentration. In this work a GFP construct was used which is under the control of a constitutive cytomegalovirus promoter (pGFPtpz.cmv). Transfection of this GFP construct served as a control for transfection efficiency and to monitor squelching (non-specific inhibition of luciferase reporter gene activity due to titration of transcriptional factors by cotransfected expression constructs). For GFP assay $50 \mu \mathrm{l}$ of cell extracts were taken and pipetted into microplate ( $96 \mathrm{~K}$, Greiner $\mathrm{GmbH}$, Frickenhausen). Microplates were read by Fusion $^{\text {TM }}$ (Packard) with excitation/emission wavelengths of $485 \mathrm{~nm}$ and $530 \mathrm{~nm}$ respectively.

\section{2.9 Immunocytofluorescence}

InR1G9 cells were grown on poly-L-lysine $(100 \mu \mathrm{g} / \mathrm{ml}$, Sigma, Taufkirchen $)$ coated glass coverslips ( 22 x $22 \mathrm{~mm}$ by Krannich Corporation, Göttingen) in complete medium for $24 \mathrm{~h}$ at $37^{\circ} \mathrm{C}$ in the incubator. The coverslips were placed into $6-\mathrm{cm}$ plates. Next day, the complete medium was replaced by medium containing BSA and antibiotics and the cells were further let to be grown for $3-4 \mathrm{~h}$ at $37^{\circ} \mathrm{C}$. Then fresh medium containing BSA and antibiotics replaced the old one and simultaneously the cells were treated for additional $3 \mathrm{~h}$ with GSK3 inhibitors or received only the solvent at $37^{\circ} \mathrm{C}$. When ready the cells were washed once with $1 \mathrm{x}$ PBS and fixed in 2\% paraformaldehyde (Sigma, Taufkirchen) for $30 \mathrm{~min}$ at RT. Next the coverslips were extensively washed in PBS and the proteins were "blocked" for unspecific binding in TBS-T plus 5\% BSA (similarly to western blotting procedure) for $1 \mathrm{~h}$ at RT with gentle shaking. Then, the coverslips were incubated with primary antibody for $\beta$-catenin in blocking solution (dilution 1:500 to 1:1000) for $1 \mathrm{~h}$ at RT, washed three times in TBS-T and incubated with secondary antibody (Cy-2 goat anti-mouse $\operatorname{IgG}(\mathrm{H}+\mathrm{L})$, Jackson Immunoresearch) for $1 \mathrm{~h}$ at RT (dilution 1:100). After washing three times in TBS-T, the dye DAPI was applied for nuclear staining dissolved in PBS in 1:300 (stock solution 31.25 $\mathrm{mg} / \mathrm{ml}$ ) for $10 \mathrm{~min}$ at RT. The cells were washed twice in PBS for $10 \mathrm{~min}$ and embedded in $\mathrm{DAKO} \circledast$ Fluorescent Mounting Medium on glass slides (ca. 76 × $26 \mathrm{~mm} / 3$ x 1 inch by Krannich Corporation, Göttingen). Cells were visualized under fluorescent microscope (Carl Zeiss, Jena) at a magnitude level of $63 \mathrm{x}$ times with the Openlab software.

Cy2 conjugated antibody: DAPI :
Excitation : $492 \mathrm{~nm}$

Excitation : $345 \mathrm{~nm}$
Emission : $510 \mathrm{~nm}$

Emission : $455 \mathrm{~nm}$ 


\section{2. 10 Nuclear Extracts from Tissue Culture Cells}

This protocol was scaled for $15 \mathrm{~cm}$ dishes of adherent cells at $70-90 \%$ confluence.

Medium was removed and cells were placed on ice and wash cells $2 \mathrm{x}$ with ice cold PBS. 1 $\mathrm{ml}$ cold PBS was added. Cells were scraped and transferred to microfuge tube. They were spinned at $4{ }^{\circ} \mathrm{C}$ at $2500 \mathrm{rpm}$ for $3 \mathrm{~min}$ and the supernatant was removed. $1 \mathrm{ml}$ cold buffer $\mathrm{A}$ was added and the mixture was pipetted up and down to resuspend cells, which were subsequently left on ice for $10 \mathrm{~min}$. Then they were centrifuged at $4^{\circ} \mathrm{C}$ at $3500 \mathrm{rpm}$ for $5 \mathrm{~min}$ and supernatant was removed. To pellet (crude nuclei) $50 \mu \mathrm{l}$ buffer $\mathrm{C}$ was added, pipetted up and down several times, then vortexed in cold room for $15 \mathrm{~min}$ and spinned for $10 \mathrm{~min}$ at $4^{\circ} \mathrm{C}$ at maximum speed. Finally, the supernatant was transferred to a fresh tube. Proteins were precipitated with $300 \mu 110 \%$ TCA / acetone for $3 \mathrm{~h}$ at $-20^{\circ} \mathrm{C}$, then spinned for $10 \mathrm{~min}$ at $4^{\circ} \mathrm{C}$ at maximum speed to get a protein pellet and wash $2 \mathrm{x}$ with acetone. Pellet was dried for 5 min at RT. 30-50 $\mu 1$ lysis buffer was added to protein pellet and vortexed for 20 min at RT to dissolve proteins. (Never heat the solution above $30^{\circ} \mathrm{C}$ because this might cause carbamylation of proteins.) The volume of lysis buffer depends on the expected amount of protein. A $15 \mathrm{~cm}$ dish should give about 200-500 $\mu \mathrm{g}$ nuclear proteins. At the end you need to have about $4 \mathrm{mg}$ protein in not more than $350 \mu \mathrm{l}$ of lysis buffer.)

Then, fractions were pooled and the amount of protein was measured by Bradford method.

\section{Buffer A:}

$\begin{array}{lr}\text { KCl } & 15 \mathrm{mM} \\ \text { HEPES pH 7.6 } & 10 \mathrm{mM} \\ \mathrm{MgCl}_{2} & 2 \mathrm{mM} \\ \text { EDTA } & 0.1 \mathrm{mM} \\ \text { NP-40 } & 0.1 \%\end{array}$

Buffer C:

$\begin{array}{lr}\mathrm{NaCl} & 0.42 \mathrm{M} \\ \text { HEPES pH } 7.9 & 20 \mathrm{mM} \\ \text { Glycerol } & 25 \% \\ \text { EDTA } & 0.2 \mathrm{mM}\end{array}$

prepare stock solutions and add before use (per $10 \mathrm{ml}$ ) :

1 tablett Protease inhibitor cocktail (Amersham Biosciences)

Lysis buffer $(5 \mathrm{ml})$ :

$\begin{array}{lr}\text { Urea } & 2.4 \mathrm{~g} \\ \text { Thiourea } & 0.76 \mathrm{~g} \\ \text { CHAPS } & 0.2 \mathrm{~g} \\ \text { DTT } & 0.1 \mathrm{~g} \\ \text { Tris } & 0.048 \mathrm{~g}\end{array}$




\section{2. 11 Two-dimensional gel electrophoresis (in collaboration with Prof. Walther's laboratory, Greifswald, Germany)}

Nuclear proteins $(1-4 \mathrm{mg})$ were diluted in $350 \mu \mathrm{l}$ of lysis buffer and applicated onto Immobiline DryStrips at $\mathrm{pH} 4.0-7.0$ and focused after their isoelectric points for approximately $48 \mathrm{~h}$ (time also includes a $12 \mathrm{~h}$ rehydration period prior to focusing). The $\mathrm{x}-$ axis refers to gradient from $\mathrm{pH} 4.0$ on the left and $\mathrm{pH} 7.0$ on the right hand side. After focusing the strips were equilibrated in two different buffers both containing SDS, one containing DTT the other iodacetamide to carbamylate free sulfhydryl groups. Then, the strips were put on top of a $12.5 \%$ acrylamide gel and run overnight at constant voltage. The $y$-axis refers to the molecular weight of the proteins. As a protein standard a prestained protein marker (P7708, New England Biolabs) was used. The bands from top to bottom are : $175,83,62,47,32,25,16,6 \mathrm{kDa}$. The gel was fixed in $12.5 \% \mathrm{TCA} / 50 \%$ methanol for at least $4 \mathrm{~h}$ and stained overnight with a Coomassie staining.

\section{2.12 MTT test}

The MTT test is a method to elucidate the cytotoxic effects of various drugs. It can give a precise indication of mitochondrial function and thus is a marker of living cells (Mosmann, $\mathrm{J}$ Immunol Meth, 1983, 55-63). The principle behind the test consists of measuring the succinate dehydrogenase mitochondrial activity of living cells. This enzyme by cutting the tetrazolium cycle makes the MTT, originally yellow in colour, turn into blue formazon crystals. After dissolution of these crystals, a spectrophotometric reading is performed. The optical densities obtained are directly proportional to the number of living cells. Therefore, the viable cell will be intense blue while in the case of necrotic cell it will be white verging on transparent. The cytotoxic effect of a sample can be evaluated as the percentage of living cells in relation to the cells treated only with the solvent.

The following protocol was used :

Cells were plated in complete medium in a sterile 96 well plate (Sarstedt, Nümbrecht) at a density of 10,000-20,000 cells per well at a final volume of $100 \mu \mathrm{l}$. Next day, the medium was removed and replaced medium containing BSA and antibiotics. After $1 \mathrm{~h}$ cells were treated with different substances for $24 \mathrm{~h}$ and then followed adding $10 \mu \mathrm{l}$ of MTT reagent (5 $\mathrm{mg} / \mathrm{ml}$ in PBS) per well and placed in the incubator at $37^{\circ} \mathrm{C}$ for $1-3 \mathrm{~h}$. Next, $100 \mu \mathrm{l}$ of $20 \%$ SDS in $0.02 \mathrm{~N} \mathrm{HCl}$ was added per well. The cells were further incubated at $37^{\circ} \mathrm{C}$ for at least $18 \mathrm{~h}$. Next day, the plate was inserted into the spectrophotometer (UV Max, Molecular Devices, Menlo Park, USA) and optical density was measured at $550 \mathrm{~nm}$. Results were analysed with software package called "Softmax". 


\section{2. 13 Software}

Restriction mapping, DNA/protein sequence analysis and database searching was performed using either the GCG package -Genetics Computer Groups- (GCG, Madison) or various others internet sites, such as the one from the National Centre for Biotechnology Information, USA (URL: http://www.ncbi.nlm.nih.gov) for BLAST search (Basic Local Alignment Search Tool).

Statistic analysis and plotting of graphs was performed with the Sigma Plot Programme (Jandel Scientific, Erkrath). 


\section{RESULTS}

\section{1 Effect of GSK3 $\beta$ overexpression on glucagon gene transcription}

As a first approach to investigate the role of GSK3 $\beta$ in the regulation of glucagon gene transcription, various GSK3 $\beta$ constructs (see Fig.8), whose expression was driven by the CMV promoter, were transiently transfected into the glucagon-producing pancreatic islet cell line, InR1G9 (cDNAs kindly provided by Dr. I. Dominguez, Boston, USA). They were transfected together with a luciferase reporter gene, under the control of 350 base pairs of the 5'-flanking region of the rat glucagon gene.

As shown in Fig.9, left panel, overexpression of GSK3 $\beta$ wild type resulted in a two-fold enhancement of glucagon gene transcription under basal conditions. Similar results were obtained when an "always-active" mutant (Shaw et al., 1997), which carries a point mutation at Ser9 (kindly provided by Dr. D. Schmoll, Greifswald, Germany), was transfected together with the reporter gene-350GluLuc (Fig.9).

The enhancement observed is due to enzymatic activity, since overexpression of a "kinasedead" mutant (Dominguez et al., 1995), carrying a point mutation within the kinase domain at the ATP-binding site (substitution of Lys85 for Arg), had no effect on transcription (Fig.9).

To control for specificity, GSK3 $\beta w t$ was transfected with another reporter gene, -711cfosLuc, and had no effect on its transcription as shown in Fig.9, right panel.

\begin{tabular}{|c|c|}
\hline CMV & GSK3 $\beta$ wt \\
\hline & wild type \\
\hline & $\ldots . . . \mathrm{L} \vee \mathrm{A} \mathrm{I} K \mathrm{~K} \vee \mathrm{L} \mathrm{Q} .$. \\
\hline CMV & GSK3 $\beta$ R85 \\
\hline & kinase "dead" mutant \\
\hline & MSGRPRTT SFAES... \\
\hline CMV & GSK3 $\beta$ A9 \\
\hline
\end{tabular}

Not inhibited by Insulin

Fig. 8. GSK3 $\beta$ constructs under the control of the CMV promoter

GSK3 $\beta$ rat wild type (wt) full length cDNA was expressed under the control of a CMV promoter. GSK3ßR85 carries a point mutation at the ATP binding site, Arg85, that renders it catalytically inactive. GSK3 $\beta A 9$ carries a point mutation at Ser9 and, therefore, it cannot be inhibited by PKB in response to insulin. 

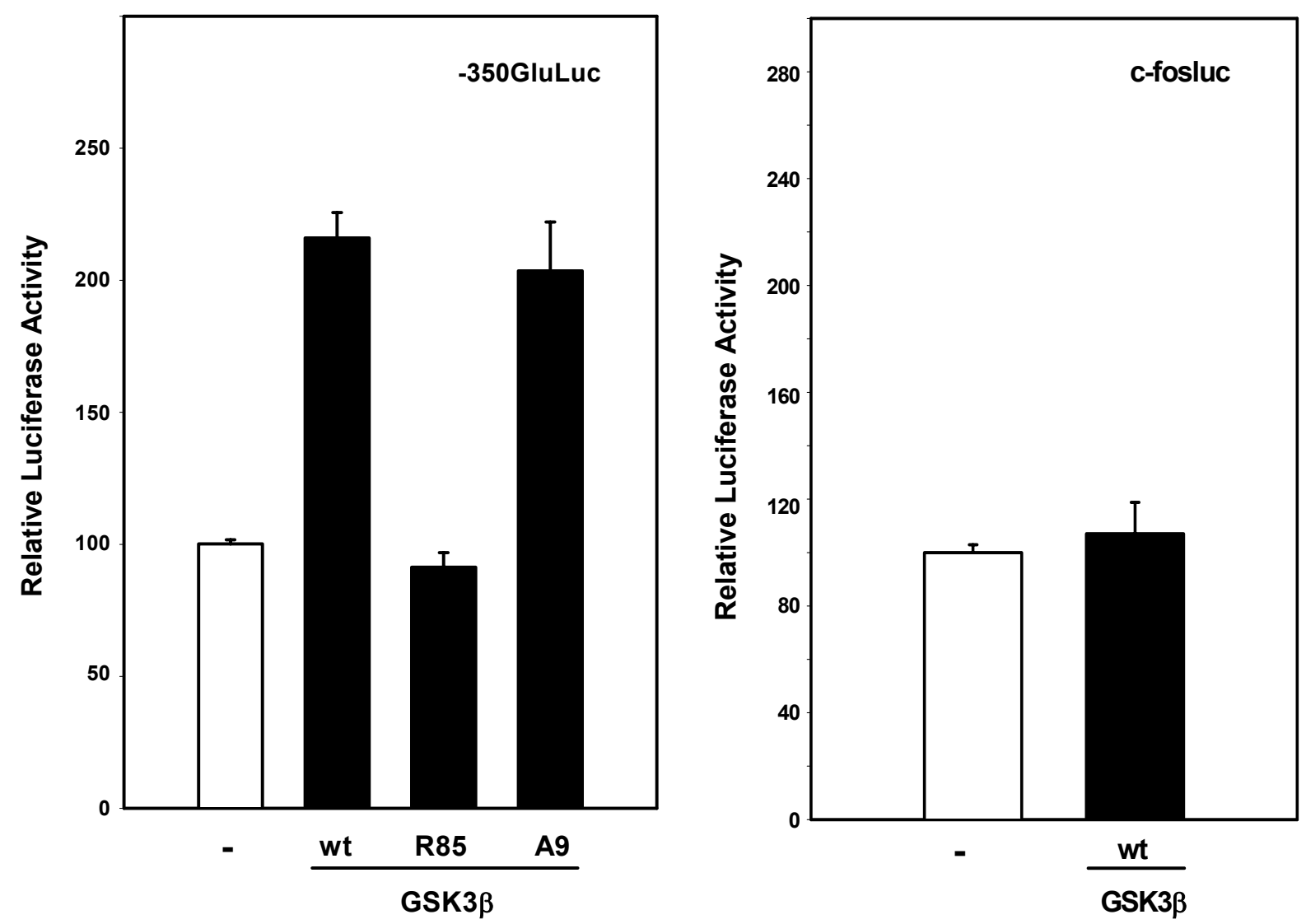

Fig. 9. Effect of GSK3 $\beta$ overexpression on glucagon gene transcription

A reporter gene (-350GluLuc, $2 \mu \mathrm{g} / 6$-cm dish) under the control of $350 \mathrm{bp}$ of the 5 '-flanking region of the glucagon gene was transfected into InR1G9 cells either alone or with an expression vector encoding GSK3 $\beta w t$ or GSK3 $\beta$ R85 or GSK3 $\beta A 9$ ( $3 \mu \mathrm{g} / 6$-cm dish) (left panel). A reporter gene under the control of $711 \mathrm{bp}$ of the 5 '-flanking region of the c-fos gene (-711c-fosLuc, $2 \mu \mathrm{g} / 6-\mathrm{cm}$ dish) was transfected into InR1G9 cells either alone or with an expression vector encoding GSK3 $\beta \mathrm{wt}(3 \mu \mathrm{g} / 6-$ $\mathrm{cm}$ dish) (right panel). Luciferase activity is expressed as percentage of the mean value, in each experiment, of the activity of cells that were transfected only with the reporter gene. Values are means $\pm \mathrm{SE}$ of three independent experiments, each performed in duplicate.

\section{2 Expression and regulation by insulin of endogenous GSK3 activity in InR1G9 cells}

\section{2.1 Expression of GSK3 in InRIG9 cells}

Next, we examined the expression levels of endogenous GSK3 and the regulation of its enzymatic activity by insulin in InR1G9 cells. In collaboration with Prof.Meijer's laboratory (Roscoff, France), GSK3 was affinity purified from InR1G9 cells, as described in the paper by Primot et al. (2000). Shortly, GSK3 was purified, based on its interaction with Axin (Fagoto et al., 1999), by affinity chromatography on an immobilized fragment of Axin. The purified GSK3 was detected by western blotting. The scheme in Fig.10A explains the various steps during the purification process (for more details see 2.2.3 in Materials and Methods). Once the protein complex, consisting of GSK3 and Axin, was eluted from the Ni-NTA agarose beads, it was subjected to SDS-PAGE electrophoresis and probed with a specific 
antibody against GSK3, which recognizes both isoforms. As shown in Fig.10A lower panel, both GSK3 isoforms were detected in total extracts from InR1G9 cells. The slower migrating band corresponds to the $\alpha$ isoform $(51 \mathrm{kDa})$, while the faster to the $\beta$ isoform $(47 \mathrm{kDa})$. The four lanes represent different InR1G9 preparations.

\section{2. 2 Regulation of GSK3 enzymatic activity by insulin in InRIG9 cells}

To examine whether GSK3 activity is regulated by insulin, InR1G9 cells were cultured in medium containing no serum, to reduce background activity, and were treated with insulin $(10 \mathrm{nM})$ for various time intervals. Total cell lysates were prepared, which were subjected to SDS-PAGE electrophoresis, transferred to nitrocellulose and visualized by western blot using specific primary phospho-antibodies that recognize Ser-21/9 of GSK $3 \alpha / \beta$ respectively, only when they become phosphorylated (Fig.10B, upper panel). The above mentioned phosphoantibodies have been widely used in many studies in order to characterize the catalytic status of the kinase, in addition to enzymatic assays (Cross et al., 1995, Diehl et al., 1998, Fang et al., 2000). Insulin inhibits GSK3 activity through phosphorylation of this particular residue via PKB (Cross et al., 1995). To control for equal loading of the samples, cell lysates were also blotted against unphosphorylated GSK3 $\alpha / \beta$ (Fig.10B, lower panel).

As shown in Fig.10B, it was confirmed that both isoforms of GSK3 were expressed in InR1G9 cells (Fig.10B, lower panel). Their activity was regulated through insulin in a timedependent manner (Fig.10B, upper panel). Under unstimulated conditions GSK3 $\alpha / \beta$ was not serine phosphorylated and, therefore, catalytically active (Fig.10B). In contrast, there was a dramatic increase in the phosphorylation status of both isoforms even after five minutes of treatment with insulin, which was persistent for about three hours (Fig.10B). The phosphorylation was largely attenuated at longer time periods of insulin stimulation $(12 \mathrm{~h}$ and $24 \mathrm{~h}$ in Fig.10B). 
(A)

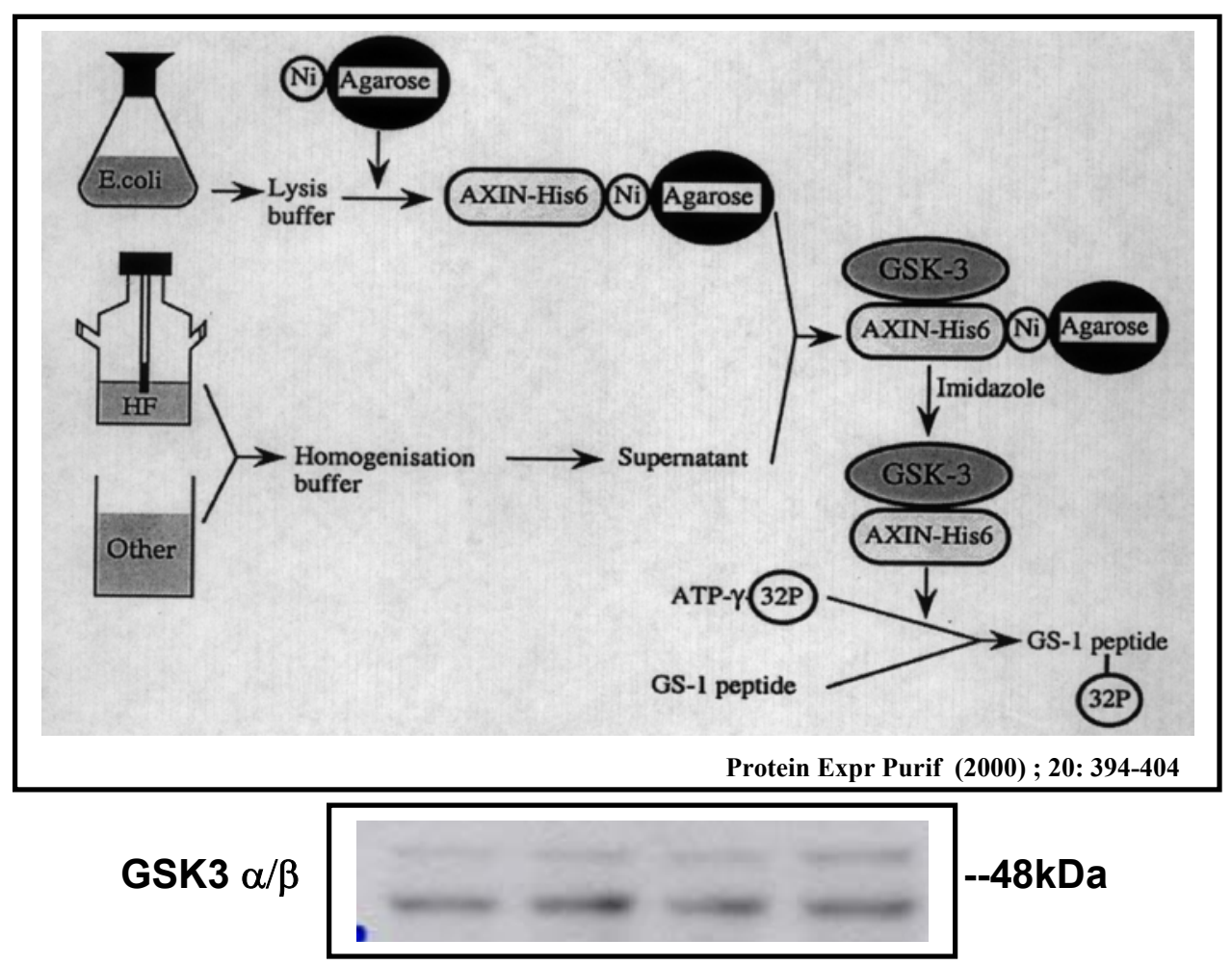

(B)

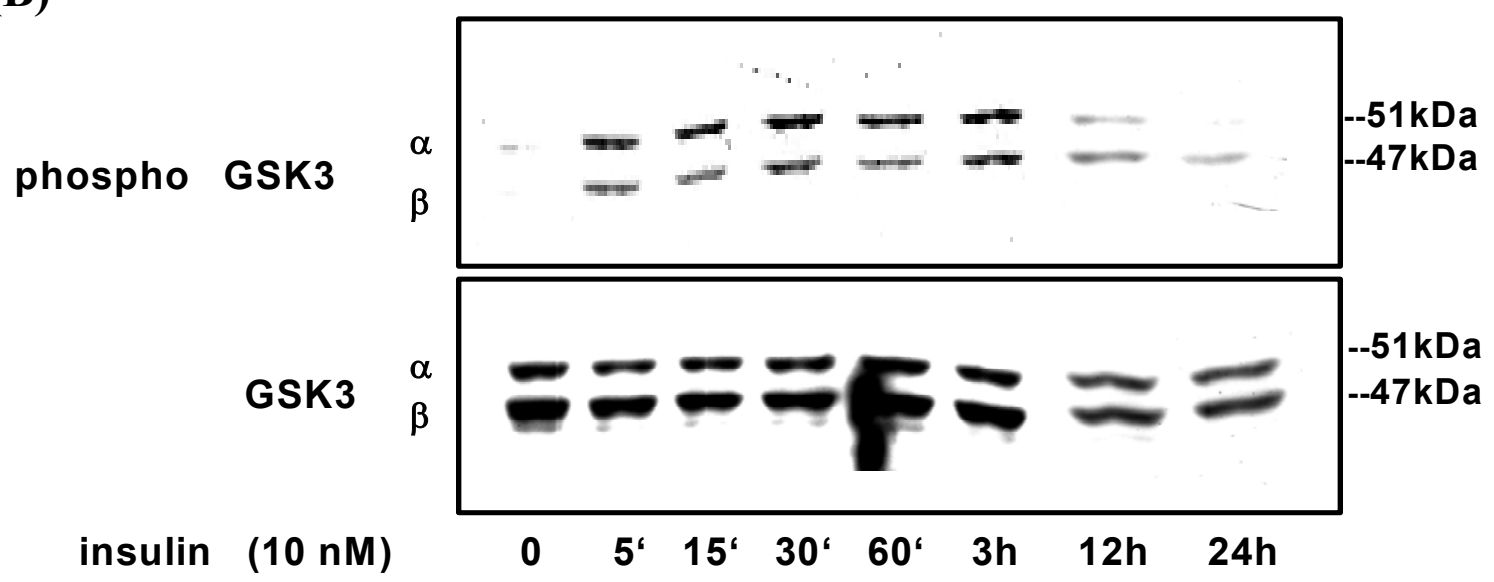

Fig. 10. Expression of GSK3 in InR1G9 cells and regulation of its enzymatic activity by insulin (A) In the upper panel the graph depicts how Axin-His6 is generated in bacteria, immobilized on NiNTA-agarose beads, and used to affinity purify GSK3, which can be further used for kinase assays or other applications. The lower panel shows endogenous levels of GSK3 from four different preparations, which have been affinity purified from InR1G9 cells and detected with a specific antibody in western blot. (B) InR1G9 cells were serum-starved for $3 \mathrm{~h}$ before incubation with insulin $(10 \mathrm{nM})$. Total cell lysates were prepared at different time points after treatment with insulin, subjected to SDS-PAGE electrophoresis, transferred to nitrocellulose and visualized by western blot using specific primary antibodies against phosphorylated Ser21/9 of GSK $3 \alpha / \beta$ respectively (upper panel, antibody from New England Biolabs, Beverly, MA, USA) or unphosphorylated GSK $3 \alpha / \beta$ (lower panel, antibody from Upstate Biotechnology, Lake Placid, NY, USA). A representative blot of three independent experiments is shown. 


\section{3 GSK3 inhibitors and their effect on glucagon gene transcription}

\section{3.1 Effect of various GSK3 inhibitors on glucagon gene transcription}

Since insulin inhibits glucagon gene transcription, inhibitors of GSK3 should mimick that effect, if GSK3 is, indeed, involved in this regulation. Therefore, the effect of seven chemically distinct compounds (see Table 3, in section 2.1.4 in Materials and Methods) was examined on glucagon gene transcription. We used the mood stabilizer valproic acid (Chen et al., 1999) and the recently developed compounds indirubin-3'-monoxime (Leclerc et al., 2001) and alsterpaullone (Leost et al., 2000) (kindly provided by Prof. Meijer, Roscoff, France), the maleimides, SB-216763 and SB-415286 (Coghlan et al., 2000) (kindly provided by GlaxoSmithKline), and the compound CT-98023 (Ring et al., 2003, Cline et al., 2002) (kindly provided by Chiron), in addition to lithium, which was the first GSK3 inhibitor to be described (Klein and Melton, 1996). Although lithium has widely been used in many studies as selective GSK3 inhibitor, it seems that it regulates also enzymes that are involved in the metabolism of inositol lipids, which are key mediators of insulin signalling (reviewed by Williams and Harwood, 2000). Therefore, in order to avoid complications in the interpretation of the results, we tested additional GSK3 inhibitors in our model system.

As shown in Fig.11, upon transfection of -350GluLuc into InR1G9 cells, insulin inhibited gene transcription by $60 \%$, consistent with previous studies (Grzeskowiak et al., 2000). Lithium negatively regulated glucagon gene transcription at a therapeutically relevant dose, and the effect was not additive or synergistic to that of insulin, since additional administration of insulin did not further inhibited transcription. Valproic acid repressed glucagon gene transcription similarly to lithium to $50 \%$, while indirubin-3'-monoxime and alsterpaullone inhibited transcription by $73 \%$ and $68 \%$ respectively. Finally, the maleimide compounds, SB-216763 and SB-415286, and the Chiron compound, CT-98023, repressed glucagon gene expression by $55 \%, 43 \%$ and $38 \%$ respectively.

Taken together, all of the GSK3 inhibitors tested could efficiently inhibit transcription of the glucagon gene at a range between $40 \%$ to $70 \%$, depending on the cellullar permeability and the dose required of each compound to elicit the maximum effect.

\section{3. 2 Effect of SB-216763 on glucagon gene transcription in a dose dependent manner}

In Fig.12, a dose-response curve is depicted of one of the GSK3 inhibitors. Cells were transiently transfected with the construct -350 GluLuc and treated for $24 \mathrm{~h}$ before harvesting with increasing concentrations of SB-216763. Maximal inhibition of glucagon gene transcription to $50 \%$ was observed at the concentration of $30 \mu \mathrm{M}$, while the $\mathrm{IC}_{50}$ value was approximately $5 \mu \mathrm{M}$. 


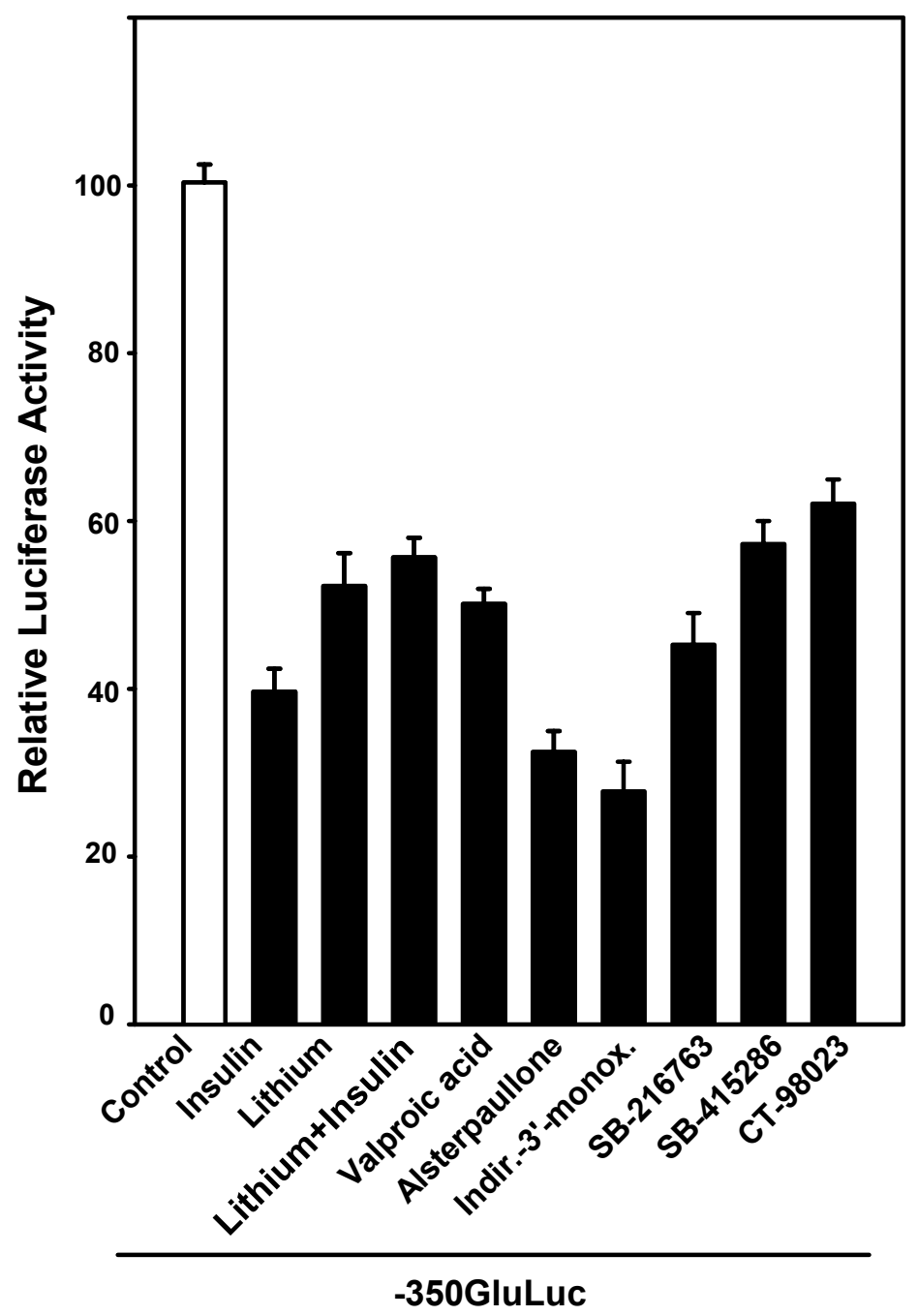

Fig. 11. Effect of various GSK3 inhibitors on glucagon gene transcription

A reporter gene under the control of $350 \mathrm{bp}$ of the 5'-flanking region of the glucagon gene ($350 \mathrm{GluLuc}, 2 \mu \mathrm{g} / 6-\mathrm{cm}$ dish) was transfected into InR1G9 cells. Cells were treated either with insulin $10 \mathrm{nM}$ or lithium $20 \mathrm{mM}$ or valproic acid $0.6 \mathrm{mM}$ or alsterpaullone $10 \mu \mathrm{M}$ or indirubin-3'-monoxime $10 \mu \mathrm{M}$ or SB-216763 $30 \mu \mathrm{M}$ or SB-415286 $50 \mu \mathrm{M}$ or CT-98023 $20 \mu \mathrm{M}$ or received the solvent only (control) for $24 \mathrm{~h}$ before harvesting. Luciferase activity is expressed as percentage of the mean value, in each experiment, of the activity of cells that were transfected only with the reporter gene and received no treatment. Values are means \pm SE of three independent experiments, each performed in duplicate. 


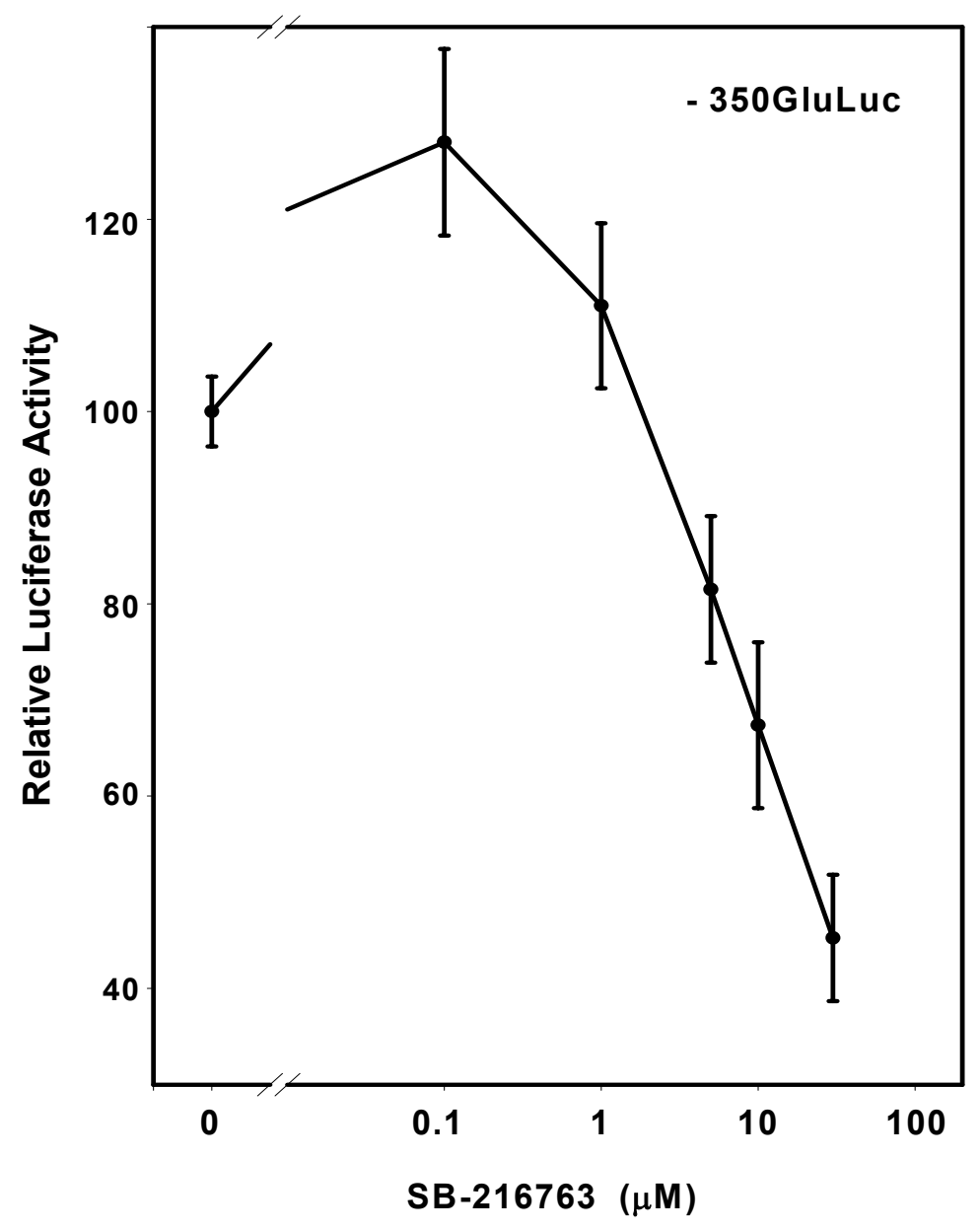

Fig. 12. Concentration response curve of the GSK3 inhibitor, SB-216763, on glucagon gene transcription

The construct -350GluLuc was transfected ( $2 \mu \mathrm{g} / 6-\mathrm{cm}$ dish) into InR1G9 cells. The cells were treated with increasing concentrations of the compound SB-216763 for $24 \mathrm{~h}$ and then harvested. Luciferase activity is expressed as percentage of the mean value, in each experiment, of the activity of cells that were transfected only with the reporter gene and received the solvent. Values are means \pm SE of three independent experiments, each performed in duplicate.

\section{3. 3 Effect of GSK3 inhibitors on the transcriptional activity of a CMV promoter}

To examine whether the GSK3 inhibitors could inhibit transcription of any promoter, we used another reporter gene. The effect of the inhibitors on gene transcription of a reporter gene, encoding for the green fluorescent protein (pCMV-GFPtpz), was tested. As seen in Fig. 13, neither insulin treated cells $(90 \%)$ nor any of the inhibitors used, alsterpaullone $(90 \%)$, indirubin-3'-monoxime (91\%), lithium (92\%), had any significant effect, as compared to control $(100 \%)$, on the activity of the reporter gene. 


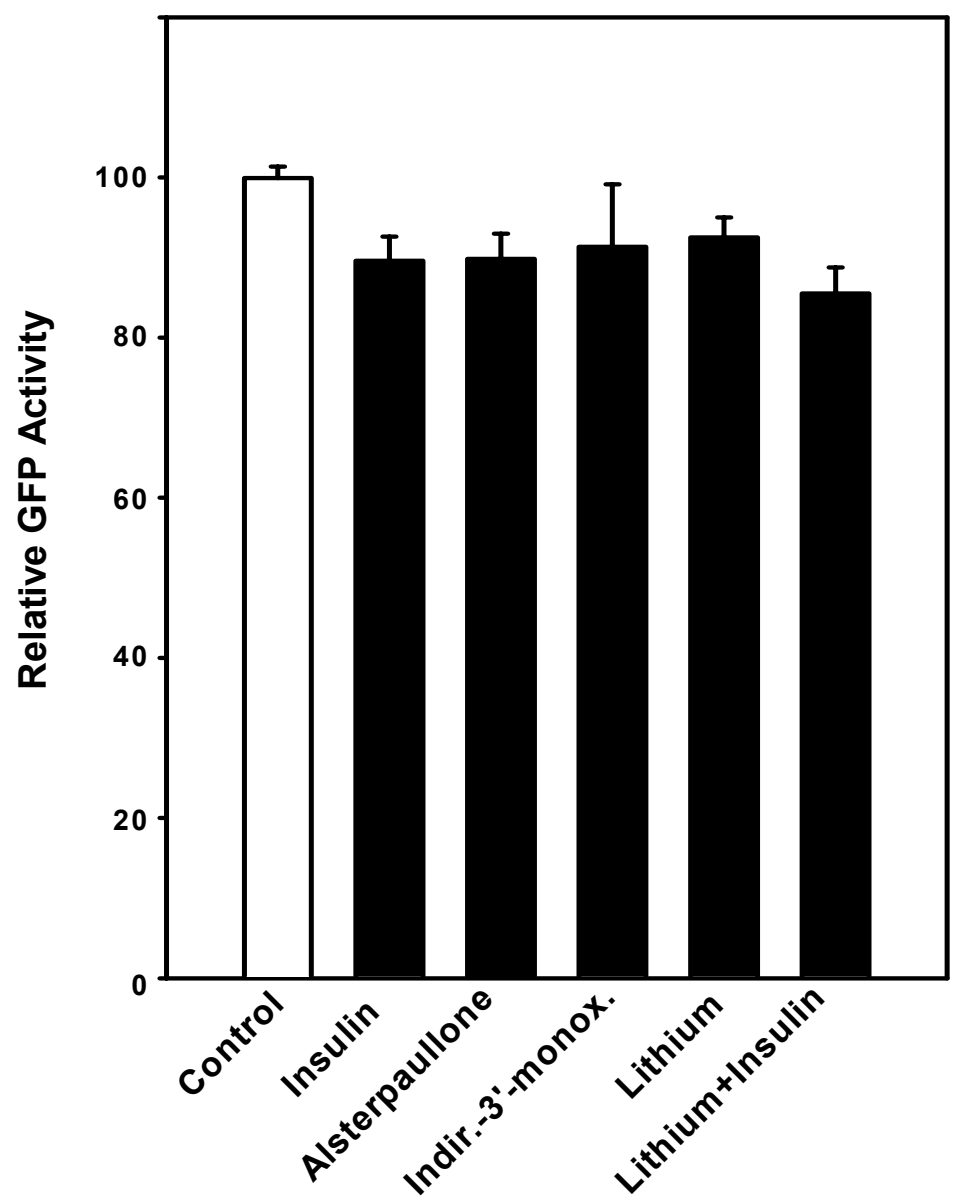

Fig. 13. Effect of GSK3 inhibitors on CMV promoter activity

InR1G9 cells were transiently transfected with the plasmid pCMV-GFPtpz $(0.5 \mu \mathrm{g} / 6-\mathrm{cm}$ dish $)$ as a second reporter gene, in addition to -350 GluLuc, to monitor transfection efficiency and treated for $24 \mathrm{~h}$ either with insulin $10 \mathrm{nM}$ or alsterpaullone $10 \mu \mathrm{M}$ or indirubin-3'-monoxime $10 \mu \mathrm{M}$ or lithium $20 \mathrm{mM}$, or receive the solvent (control). Total cell lysates were then harvested and assayed for GFP activity. GFP activity is expressed as percentage of the mean value, in each experiment, of the activity of cells that were transfected only with the reporter gene and received no treatment. Values are means \pm SE of three independent experiments, each performed in duplicate.

\section{3. 4 The GSK3 inhibitors were tested for potential cytotoxic effects via the MTT test}

In order to assess any potential cytotoxic effect of the compounds used in the above mentioned experiments, the MTT test was carried out. This test is widely used as a standard method to validate the toxicity of various compounds on cellular systems. The optical densities obtained are directly proportional to the number of living cells; the higher the density value more cells survive. As shown in Fig.14, lithium (97\%), SB-415286 (108\%), CT-98023 (112\%) and valproic acid (88\%) treated cells behaved similar to control cells $(100 \%)$ and there was no significant difference in the optical density. The compound SB216763 seemed to promote survival, since the SB-216763 treated cells (141\%) exerted the highest optical density, as compared to control cells. 


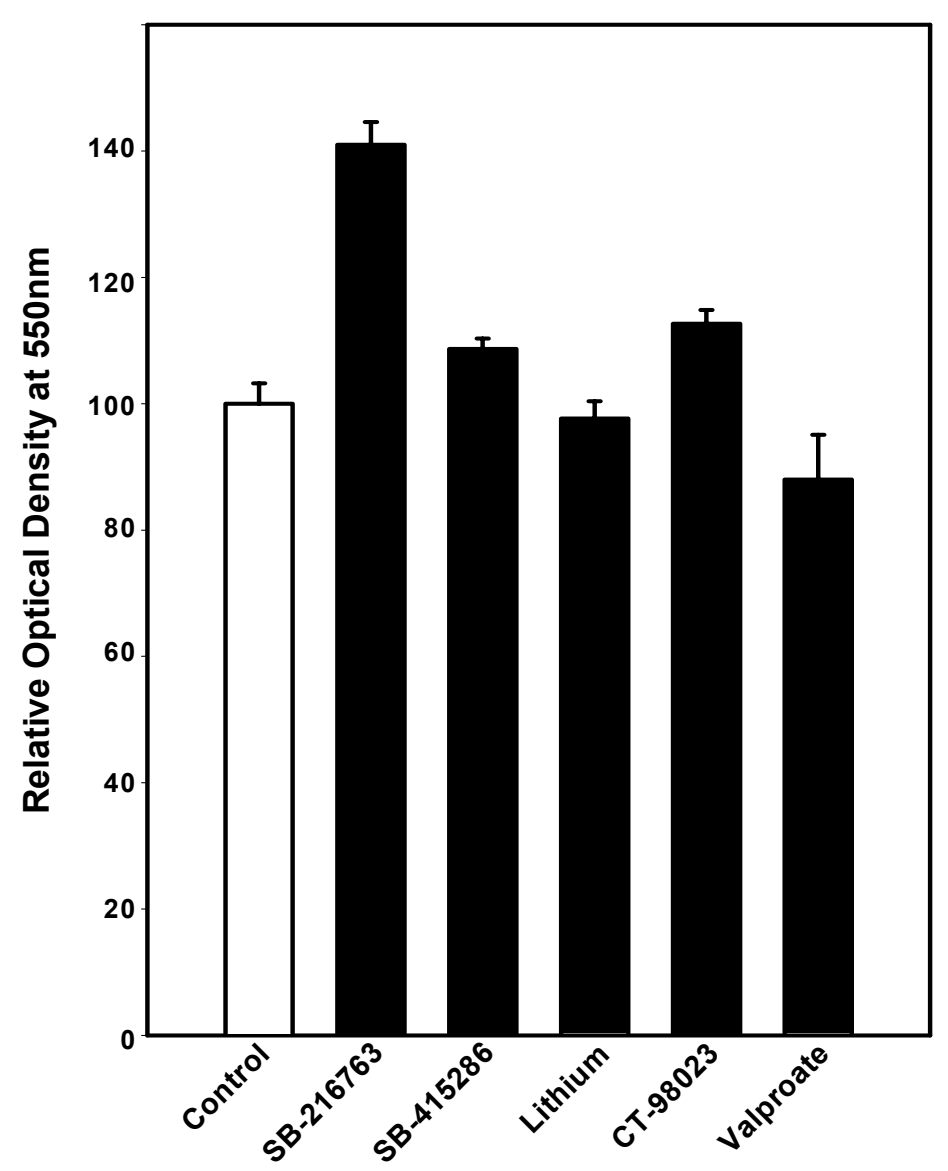

Fig. 14. GSK3 inhibitors were tested for potential cytotoxic effects via the MTT test

InR1G9 cells were either treated with the GSK3 inhibitors (SB-216763 $30 \mu \mathrm{M}$, SB-415286 $50 \mu \mathrm{M}$, lithium $20 \mathrm{mM}$, CT-98023 $20 \mu \mathrm{M}$, valproic acid $1 \mathrm{mM}$ ) or received the solvent only (control) and then assayed via the MTT test for potential cytotoxic effects. Values are expressed as percentage of the mean value of the absorption of control cells at $550 \mathrm{~nm}(\mathrm{n}=3)$.

3. 3. 5 GSK3 inhibitors abolished the effect of GSK3 $\beta$ wt overexpression on glucagon gene transcription

Since GSK3 inhibitors suppressed glucagon gene transcription, they should also abolish the enhancement observed on gene transcription by GSK3 $\beta$ overexpression (see Fig.11). For that reason the construct -350 GluLuc was transfected together with the plasmid GSK3 $\beta w t$ in InR1G9 cells and the cells were treated with various GSK3 inhibitors. As seen in Fig.15, administration of either indirubin-3'-monoxime or alsterpaullone almost completely abolished the increase on glucagon gene transcription by overexpression of GSK3, while lithium was somehow less effective, but could still act in the same manner (see Fig.11 for comparison). 


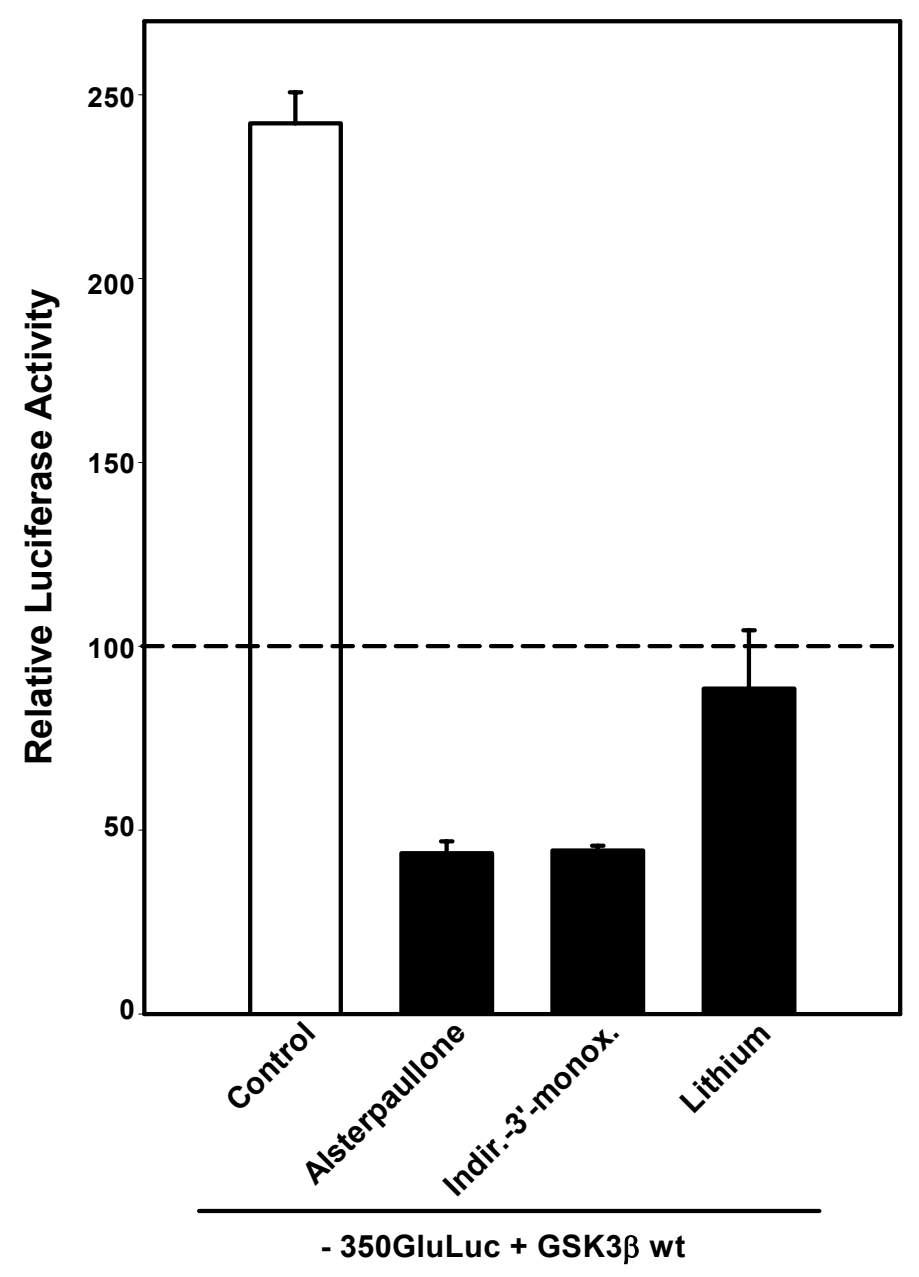

Fig. 15. Effect of GSK3 inhibitors on the stimulation of glucagon gene transcription by GSK3 $\beta$ wt overexpression

A reporter gene under the control of $350 \mathrm{bp}$ of the 5 '-flanking region of the glucagon gene (350GluLuc, $2 \mu \mathrm{g} / 6-\mathrm{cm}$ dish) was transfected into InR1G9 cells together with GSK3ßwt $(3 \mu \mathrm{g} / 6-\mathrm{cm}$ dish). Cells were treated either with alsterpaullone $10 \mu \mathrm{M}$ or indirubin-3'-monoxime $10 \mu \mathrm{M}$ or lithium $20 \mathrm{mM}$ or received the solvent only (control) for $24 \mathrm{~h}$ before harvesting. Luciferase activity is expressed as percentage of the mean value, in each experiment, of the activity of cells that were transfected only with the reporter gene (dashed line, see Fig.11) and received no treatment. Values are means \pm SE of three independent experiments, each performed in duplicate.

\section{3. 6 Inhibition of GSK3 activity in InR $1 G 9$ cells as revealed by ex vivo assay}

To investigate the consequences of SB-216763 treatment on GSK3 activity in intact cells, an ex vivo kinase assay was performed utilising crude cell lysates, as described by Cross et al. (2001) (for more details see 2.2.6 in Materials and Methods). GSK3 activity is measured based on its property to phosphorylate a substrate peptide, which has been previously prephosphorylated by a priming kinase. Treatment with the GSK3 inhibitor SB-216763, at a dose similar to what has been used in the transfection experiments before, resulted in a significant inhibition of GSK3 activity by $75 \%$ compared to control, as shown in Fig. 16. 


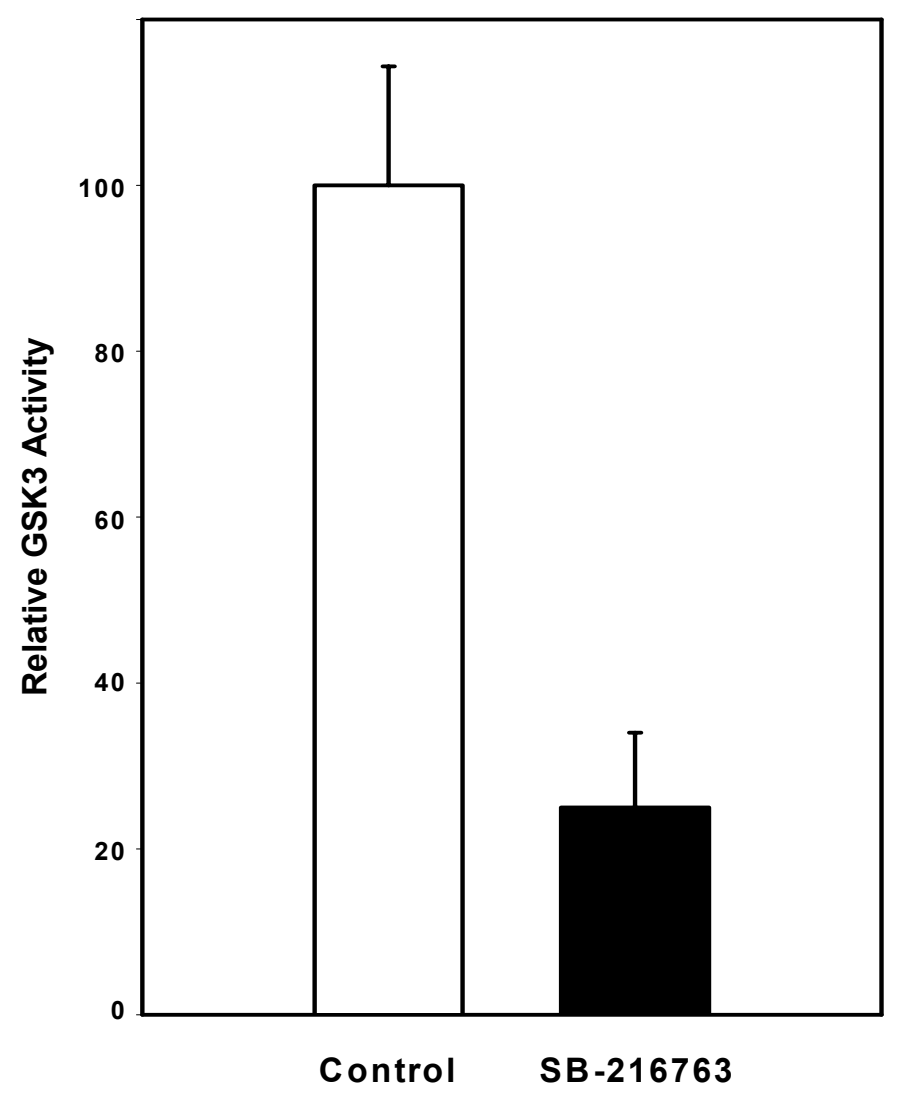

Fig. 16. SB-216763 inhibits GSK3 activity in InR1G9 cells

InR1G9 cells were serum-starved for $3 \mathrm{~h}$ and then treated for 90 min either with $30 \mu \mathrm{M}$ of SB-216763 or with the solvent only. Crude lysates were prepared and assayed for total GSK3 activity using a direct in vitro peptide kinase assay. Data are expressed as a percentage of total GSK3 activity measured in vehicle-treated cells $( \pm$ SEM, $n=2)$.

\section{3. 7 GSK3 inhibitors stabilized $\beta$-catenin protein levels}

To analyze further and characterize the mode of action of GSK3 inhibitors, we assayed changes in a putative downstream substrate of GSK3 in vivo. As mentioned in the introduction, GSK3 seems to exist in two different pools within the cells (Weston and Davis, 2001). Wnt-mediated inhibition of GSK3 activity has been reported to correlate with the stabilization and accumulation of cytoplasmic $\beta$-catenin levels (Polakis 2000, van Noort et al., 2002). Since most of the compounds used so far inhibit GSK3 by competing with ATP for binding, in principle, they should be capable of targeting both pools of the enzyme. Therefore, we have chosen to study the endogenous protein levels of $\beta$-catenin after treatment of InR1G9 cells with the GSK3 inhibitors. 
As a first approach, we examined $\beta$-catenin levels by immunofluorescent studies. After treatment of InR1G9 cells with the GSK3 inhibitors alsterpaullone and SB-415286 for $3 \mathrm{~h}$, they were fixed and incubated with a primary antibody against $\beta$-catenin. In the presence of the inhibitors $\beta$-catenin protein levels were stabilized and accumulated in the cytosol, while when cells were left untreated there was hardly any protein detected (Fig.17, last column). For nuclear staining, the dye DAPI was applied (Fig.17, middle column). Representative images are shown from two separate experiments in Fig.17.

Since with that approach one cannot get quantitative results, the same experiment was performed, but this time total cell lysates were prepared, subjected to western blot analysis and probed with the same primary antibody against $\beta$-catenin that was used for the immunofluorescent studies (Fig.18A). The intensity of the bands was densitometrically quantified and plotted as shown in Fig.18B. All of the inhibitors, at the same concentration used for the transfection experiments, induced a two- to three fold enhancement in $\beta$-catenin levels, while insulin had no significant effect on its accumulation (Fig.18B).

light field
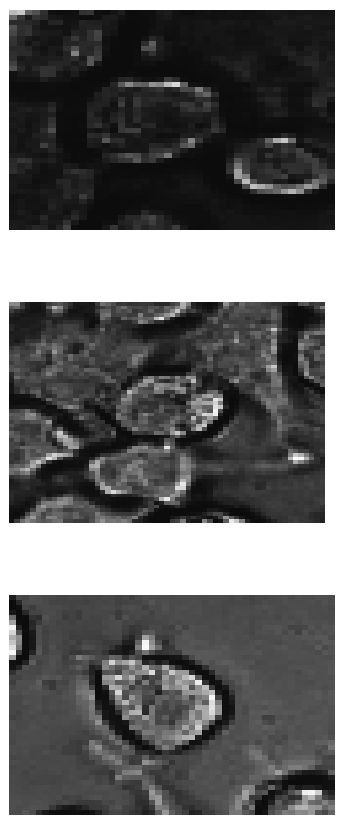

DAPI staining
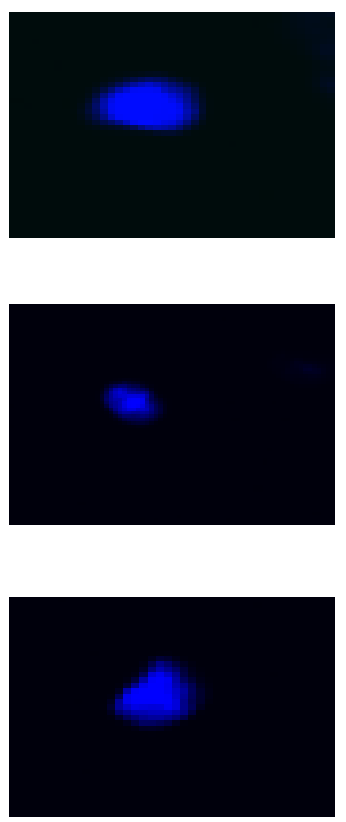

$\beta$-catenin

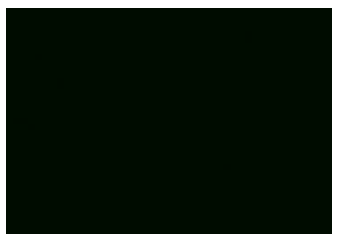

control

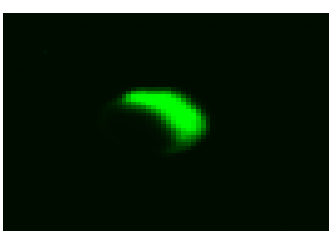

alsterpaullone $10 \mu \mathrm{M}$

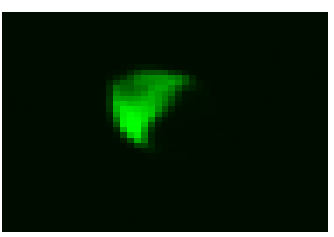

SB -415286

$50 \mu \mathrm{M}$

Fig. 17. GSK3 inhibitors induced accumulation of $\beta$-catenin in cytosol as revealed by immunofluorescence

InR1G9 cells were serum-starved before incubation for $3 \mathrm{~h}$ either in the presence of lithium $(20 \mathrm{mM})$ or SB-415286 $(50 \mu \mathrm{M})$ or left untreated (control). Then cells were fixed and incubated with primary antibody against endogenous levels of $\beta$-catenin (third column) (Transduction Laboratories, Oxford, UK) and visualized under fluorescent microscope (secondary antibody for $\beta$-catenin conjugated with cyanine, Cy2, absorption peak at $492 \mathrm{~nm}$ and emission at $510 \mathrm{~nm}$, from Jackson Immunoresearch Laboratories, West Grove, PA, USA). Nuclear staining with DAPI (second column) (absorption max. at $345 \mathrm{~nm}$ and emission at $455 \mathrm{~nm}$ ). Representative cell images are shown for each experimental condition from two separate experiments. 
(A)

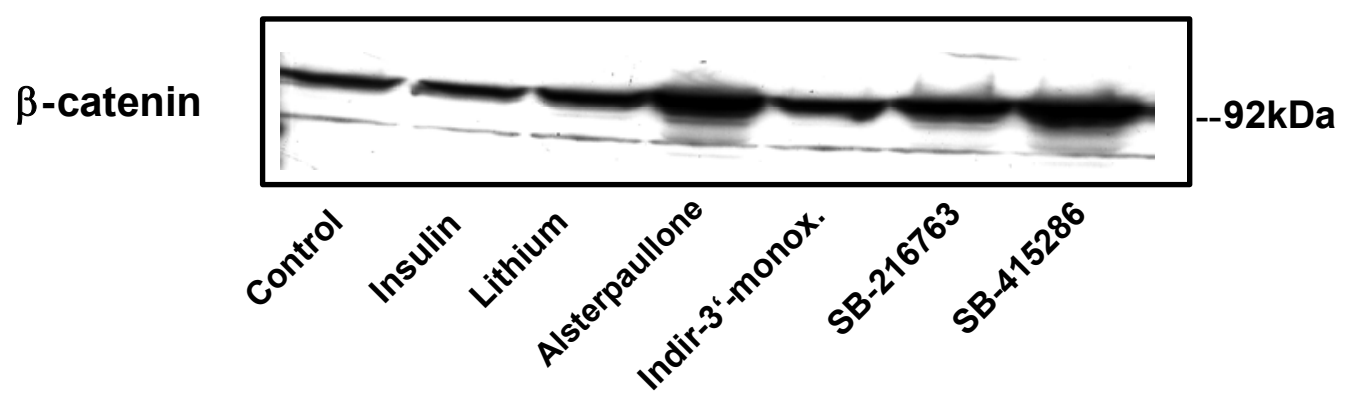

(B)

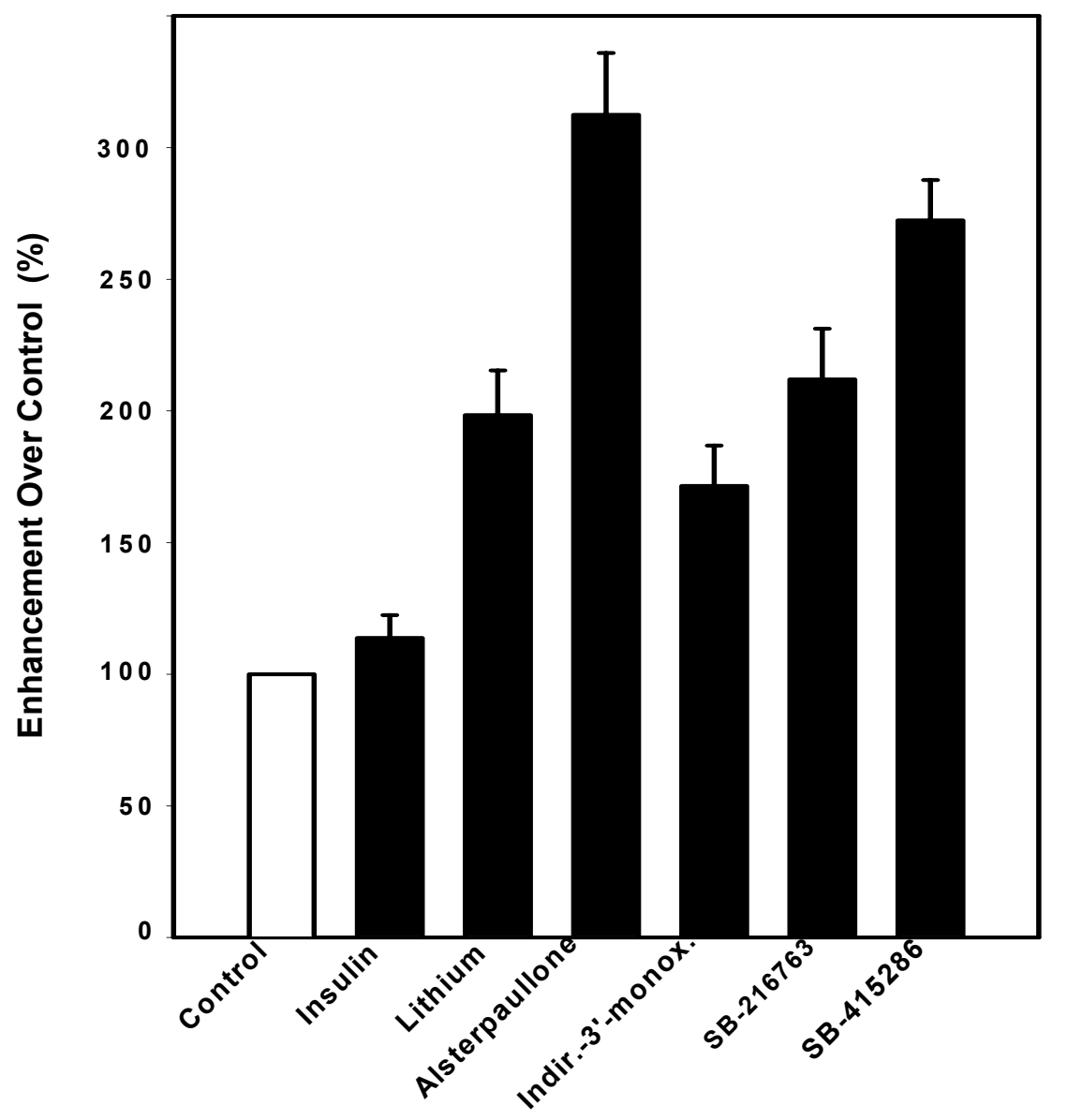

Fig. 18. GSK3 inhibitors induced stabilization of $\beta$-catenin as revealed by western blot

(A) InR1G9 cells were serum-starved before incubation for $3 \mathrm{~h}$ in the presence of insulin $(10 \mathrm{nM})$ or GSK3 inhibitors (lithium $20 \mathrm{mM}$, alsterpaullone $10 \mu \mathrm{M}$, indirubin-3'-monoxime $10 \mu \mathrm{M}$, SB-216763 $30 \mu \mathrm{M}$, SB-415286 $50 \mu \mathrm{M})$. Total cell lysates were prepared and subjected to SDS-PAGE electrophoresis. The levels of $\beta$-catenin were determined by immunoblotting with a specific primary antibody against beta-catenin (Transduction Laboratories, Oxford, UK). A representative blot from three separate experiments is shown. (B) The specific immunoreactivity from three independent experiments was quantified by densitometric analysis and plotted. 


\section{4 Deletion and internal mutation analysis of the glucagon promoter after treatment of InR1G9 cells with the GSK3 inhibitor, SB-216763}

Next, we undertook a clasical approach, based on 5'- and 3'- deletion and internal mutation analysis to examine which sequences are responsible for negative regulation of glucagon gene transcription after treatment with the GSK3 inhibitor, SB-216763.

\section{4. 1 Effect of SB-216763 on the transcriptional activity of 5'-deleted fragments of the glucagon promoter}

Expression of 5'-deleted mutant plasmids in InR1G9 cells revealed that the GSK3 inhibitor, SB-216763, could still significantly inhibit transcription by 55\%, when the 5 'end was shortened from -350 up to -292 (Fig.19). Truncation from -292 to -200 abolished responsiveness to the compound, while further deletions did not restore the repression (Fig.19). Although basal activity of the truncated 5'-deleted constructs were lower as compared to -350 GluLuc, they were still measurable and significantly above background levels. When compared with -350 GluLuc $(1.00 \pm 0.07)$, the basal activity of the 5 '-deleted constructs was $0.53 \pm 0.06$ for -292 GluLuc, $0.19 \pm 0.02$ for -200 GluLuc, $0.04 \pm 0.01$ for 169 GluLuc and $0.07 \pm 0.01$ for -60 GluLuc.

\section{4. 2 Effect of SB-216763 on the transcriptional activity of 3'-deleted fragments of the} glucagon promoter

Next, to examine the role of proximal promoter elements, a 3'-deletion analysis was performed. Fragments of the glucagon promoter with deletions at their 3' end were linked to the minimal thymidine kinase promoter $(-81$ to +52$)$ of herpes simplex virus (Fig.20, upper panel). This promoter does not respond to SB-216763 (Fig.20). The glucagon gene 5'flanking DNA from -350 to -48 conferred responsiveness to GSK3 inhibitor by $35 \%$ (Fig.20). When sequences from -350 to -91 were fused to the viral promoter, SB-216763 could not any longer inhibit transcription (Fig.20). This deletion eliminates part of the G1 element, and in particular the cis-element, where Pax6 binds. Further deletion to -150 or -

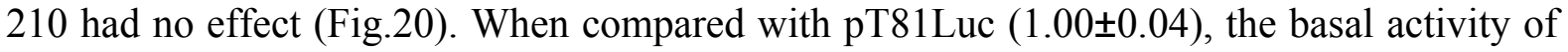
the 3 '-deleted constructs was $2.34 \pm 0.20$ for-350/-48GluLuc, $2.75 \pm 0.36$ for $-350 /-91$ GluLuc, $2.39 \pm 0.07$ for $-350 /-150$ GluLuc and $1.41 \pm 0.12$ for $-350 /-210$ GluLuc.

\section{4. 3 Effect of SB-216763 on a glucagon reporter gene that the Pax6 binding sites have been mutated}

The results from the 5'- and 3'-deletion analysis indicate that the cis-elements G1 and G3, where Pax6 binds, are required to confer inhibition of the glucagon gene transcription by SB216763. Since with such mutation analysis the binding of other transcription factors might be affected as well, a more direct approach to study the role of Pax6 in the repression of glucagon gene transcription by the GSK3 inhibitor was undertaken. The Pax6 binding sites (PISCES motif) of the glucagon promoter within either G3 or G1 or both were mutated in a way that only binding of Pax6 is affected and not of other proteins (Knepel et al., 1990, Andersen et al., 1999) (see upper panel in Fig.21). 

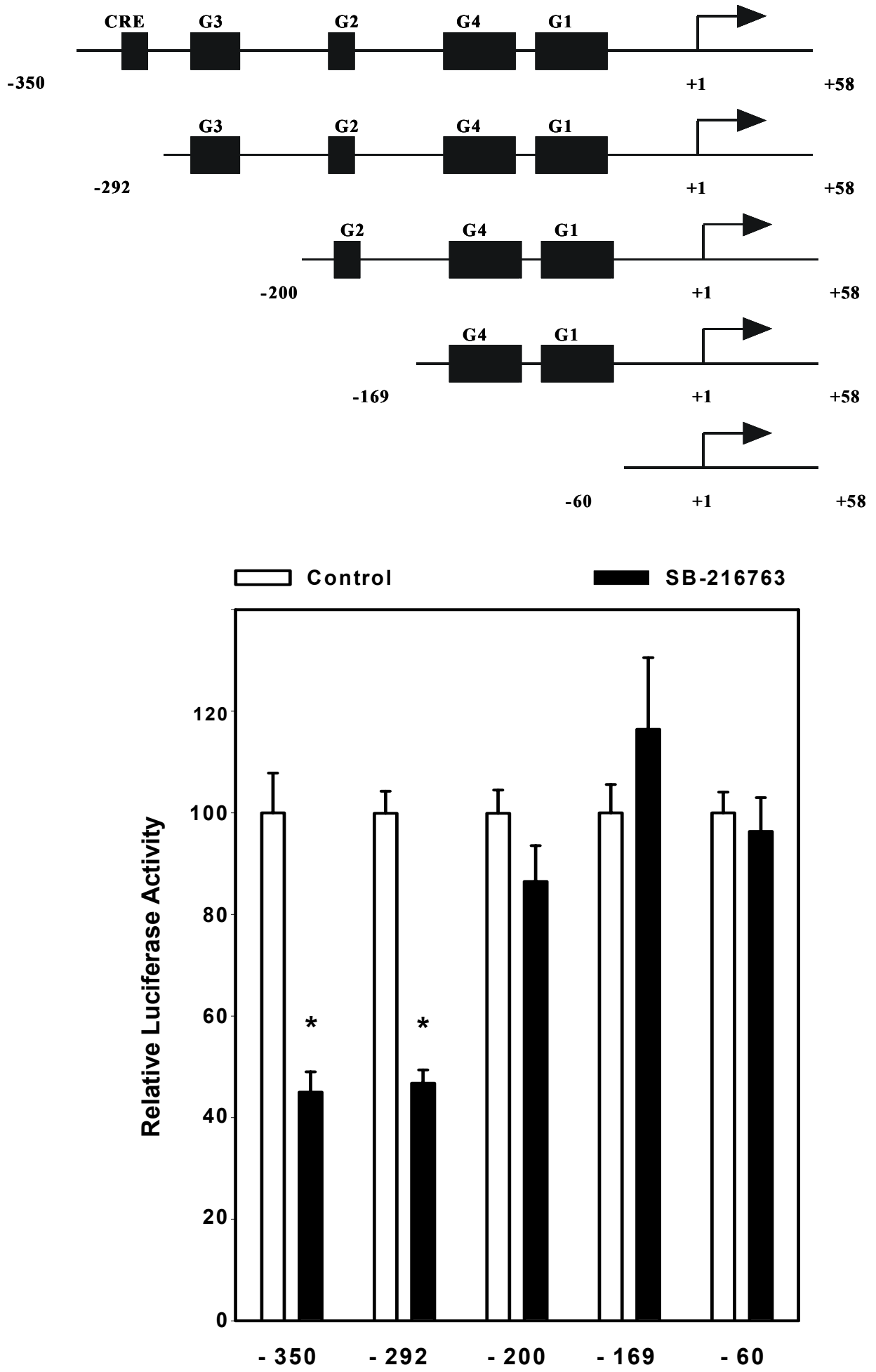

Fig. 19. Effect of SB-216763 on the transcriptional activity of 5'-deleted fragments of the glucagon promoter

The indicated constructs (upper panel) were transfected into InR1G9 cells and treated for $24 \mathrm{~h}$ with the GSK3 inhibitor, SB-216763 $(30 \mu \mathrm{M})$ or the solvent only (control). The upper panel depicts the corresponding cis-elements on the glucagon promoter. Luciferase activity is expressed as percentage of the mean value, in each experiment, of the activity measured in the respective controls. Values are means $\pm \mathrm{SE}$ of three independent experiments, each done in triplicate. *, $\mathrm{p}<0.005$ (Student's $t$-test). 


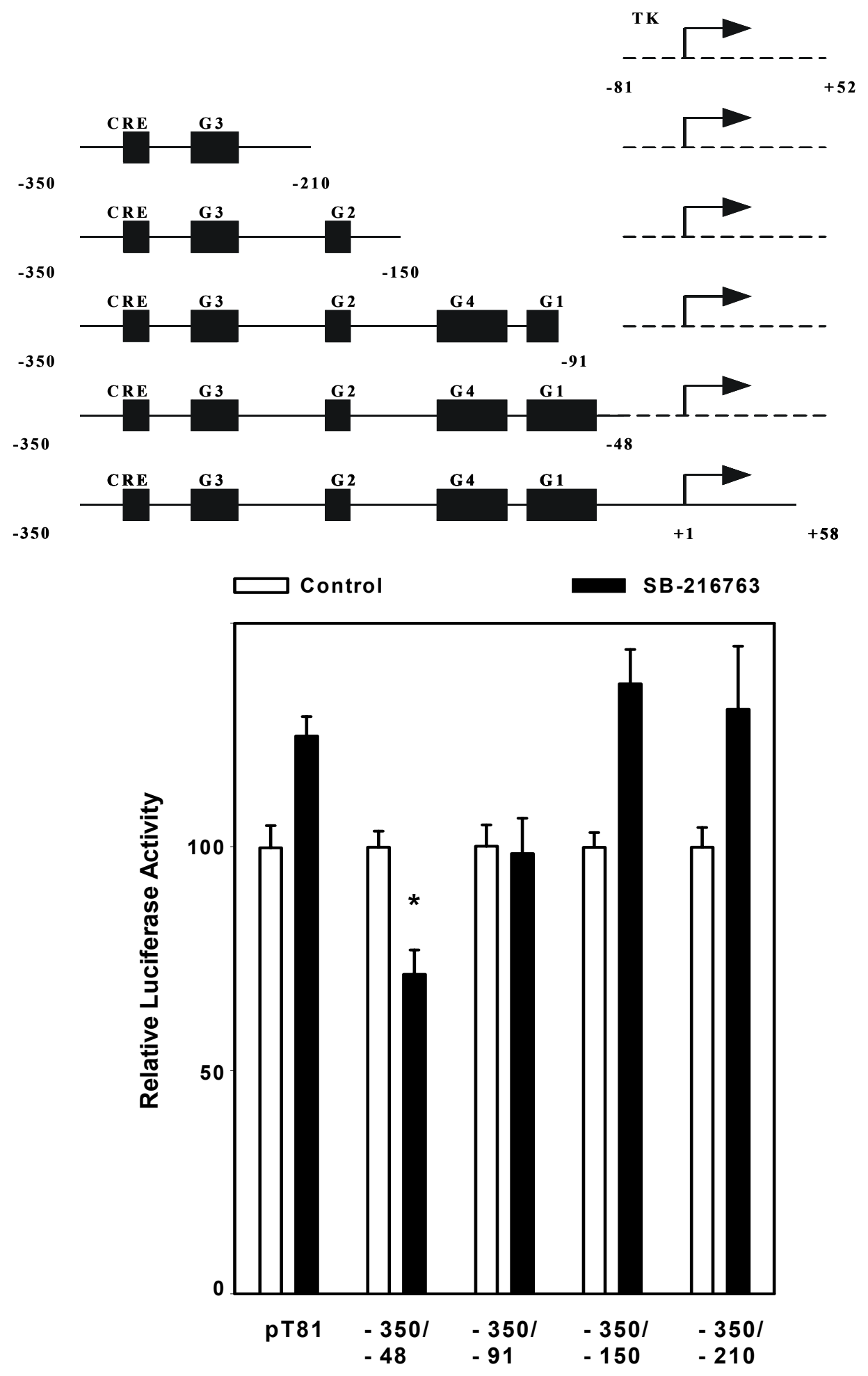

Fig. 20. Effect of SB-216763 on the transcriptional activity of 3'-deleted fragments of the glucagon promoter

The indicated constructs (upper panel) were transfected into InR1G9 cells and treated for $24 \mathrm{~h}$ with the GSK3 inhibitor, SB-216763 $(30 \mu \mathrm{M})$ or the solvent only (control). The upper panel depicts the corresponding cis-elements on the glucagon promoter. Luciferase activity is expressed as percentage of the mean value, in each experiment, of the activity measured in the respective controls. Values are means $\pm \mathrm{SE}$ of three independent experiments, each done in triplicate. ${ }^{*}, \mathrm{p}<0.005$ (Student's $t$ test).TK, thymidine kinase minimal promoter. 
As shown in Fig.21, mutations within G3A or G1 largely abolished basal activity of glucagon gene by $73 \%$ and $76 \%$ respectively. The constructs $-350(\mathrm{G} 1 \mathrm{~m})$ GluLuc and $350(\mathrm{G} 3 \mathrm{Am}) \mathrm{GluLuc}$ were still responsive to inhibition by insulin (by $30 \%$ and $33 \%$ respectively) and by the GSK3 inhibitor (by $37 \%$ and $40 \%$ respectively) (Fig.21). When combining both mutations on $\mathrm{G} 3$ and $\mathrm{G} 1$, the construct $-350(\mathrm{mG} 1+\mathrm{mG} 3 \mathrm{~A}) \mathrm{GluLuc}$ was no longer responsive neither to insulin nor to SB-216763 (Fig.21). Although basal activity of this construct was significantly reduced as compared to the other constructs, it was still measurable and significantly above background levels.

\section{5 Effect of SB-216763 on Pax6 mediated transcriptional activity}

To examine more directly, whether Pax6-dependent transcriptional activity is regulated by the GSK3 inhibitor, SB-216763, the Gal4 system was employed. Full length Pax6 cDNA was fused to the Gal4 DNA-binding domain of the respective yeast transcription factor and expression of the construct was driven under a CMV-promoter. The Gal4-Pax6 fusion protein was transiently transfected into InR1G9 cells together with a glucagon luciferase reporter gene, where both Pax6 binding sites on G3 and G1 were mutated into binding sites for the yeast transcription factor Gal4 (Grzeskowiak et al., 2000) (see Fig.22, upper panel). As shown in Fig.22, the mutation of both Pax6 binding sites decreased dramatically basal transcriptional activity of the glucagon promoter and there was virtually no effect when SB216763 was added. The expression of Gal4-Pax6 conferred basal activity and inhibition by SB-216763 by $46 \%$, which is close to the inhibition conferred on -350GluLuc (approximately 60\%) (Fig.22).

\section{6 Effect of SB-216763 on CBP mediated transcriptional activity}

Evidence suggests that the p300/CBP proteins may interact with Pax6 and function as potential coactivators (Hussain and Habener, 1999). To test the hypothesis whether GSK3 can affect CBP transcriptional activity, full length CBP was fused to the Gal4 DNA-binding domain and cotransfected with a glucagon reporter gene in which both PISCES motifs, where Pax 6 binds on G3 and G1, were mutated into binding sites for the yeast transcription factor Gal4, -350(mutG1/G3)GluLuc.

Transfection of Gal4-CBP conferred strong basal activity to the mutated reporter gene, that was inhibited by SB-216763 by about 43\% (Fig.23). This is close to the inhibition conferred by SB-216763 on -350GluLuc (approximately 60\%, Fig.23). 

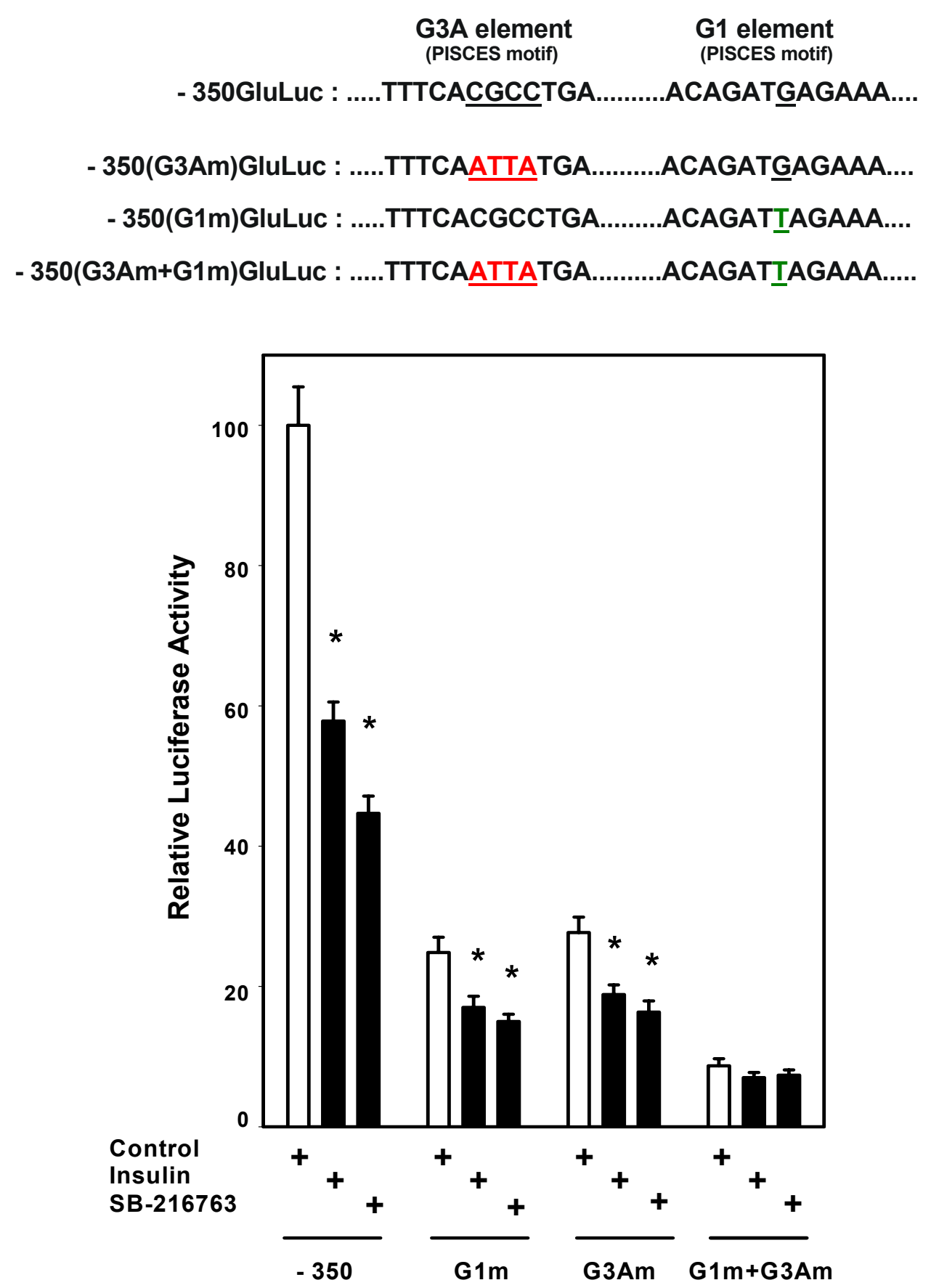

Fig. 21. Effect of SB-216763 on a glucagon reporter gene that the Pax6 binding sites have been mutated

InR1G9 cells were transfected either with -350GluLuc $(2 \mu \mathrm{g} / 6-\mathrm{cm}$ dish $)$ or $-350(\mathrm{G} 1 \mathrm{~m}) \mathrm{GluLuc}$ ( $2 \mu \mathrm{g} / 6-\mathrm{cm}$ dish) or $-350(\mathrm{G} 3 \mathrm{Am})$ GluLuc $(2 \mu \mathrm{g} / 6-\mathrm{cm}$ dish) or $-350(\mathrm{G} 1 \mathrm{~m}+\mathrm{G} 3 \mathrm{Am}) \mathrm{GluLuc}(2$ $\mu \mathrm{g} / 6-\mathrm{cm}$ dish). Cells were either treated with insulin $(10 \mathrm{nM})$ or the GSK3 inhibitor, SB$216763(30 \mu \mathrm{M})$ or left untreated. Luciferase activity is expressed as percentage of the mean value, in each experiment, of the activity of the cells that received no treatment and transfected with the construct -350 GluLuc. Values are means \pm SE of three independent experiments, each done in duplicate. ${ }^{*}, \mathrm{p}<0.05$ (Student's $t$-test). The upper panel shows the Pax 6 binding sites in G3A and G1 and which bases have been mutated on the respective constructs. 

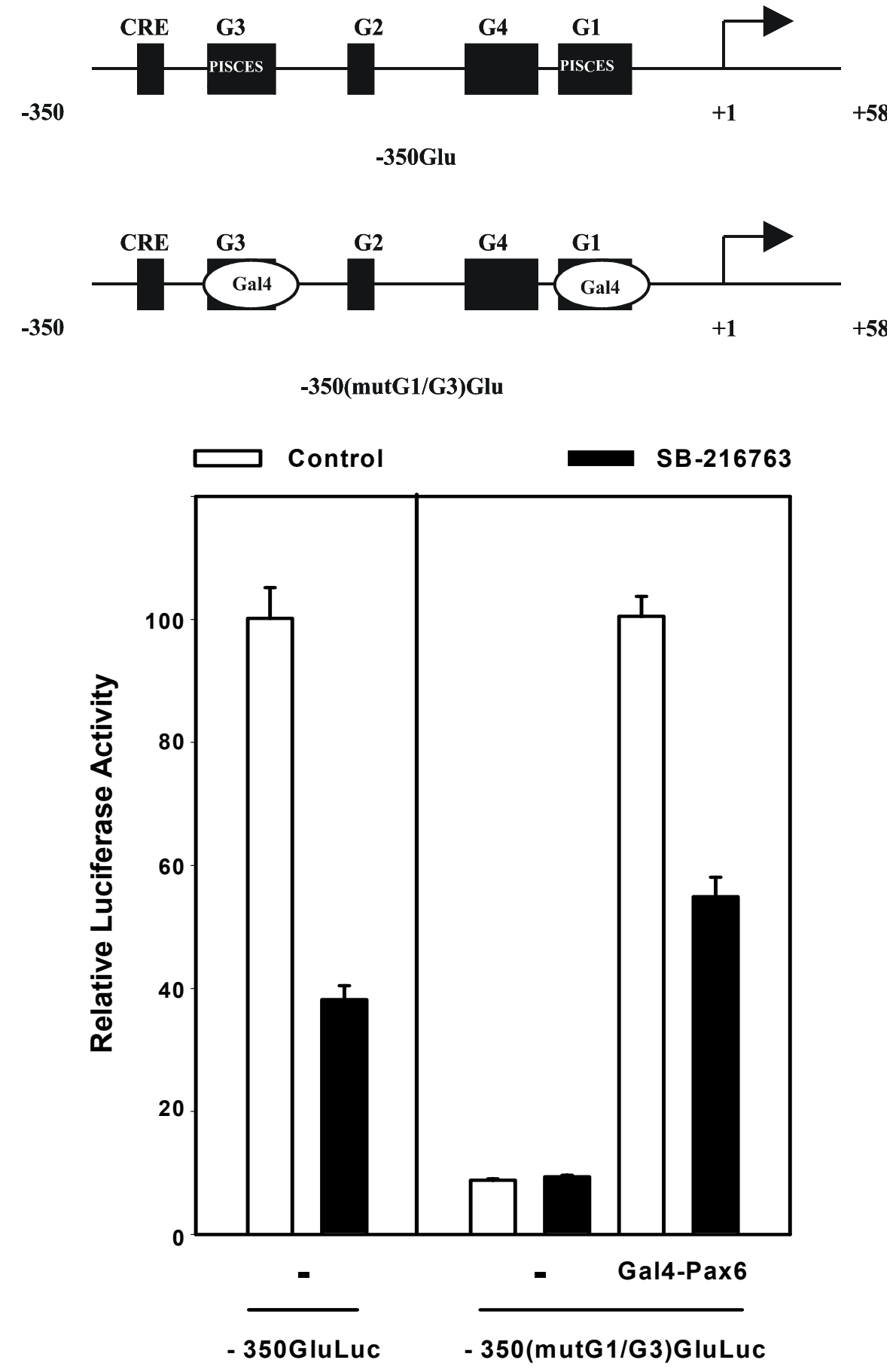

Fig. 22. Inhibition by SB-216763 of Gal4-Pax6 transcriptional activity

An expression vector encoding Gal4-Pax6 (1 $\mu \mathrm{g} / 6-\mathrm{cm}$ dish) was transfected into InR1G9 cells together with -350 (mutG1/G3)GluLuc reporter gene ( $2 \mu \mathrm{g} / 6$-cm dish) and the cells were treated with the GSK3 inhibitor, SB-216763 $(30 \mu \mathrm{M})$ or received the solvent only (control). For comparison the 350 GluLuc construct was also transfected. Luciferase activity is expressed as percentage of the mean value, in each experiment, of the activity measured in the Gal4-Pax6 or -350GluLuc controls respectively. Values are means $\pm \mathrm{SE}$ of three independent experiments, each in duplicate. On the upper panel, the scheme represents the wild type and the mutated glucagon reporter genes used. 

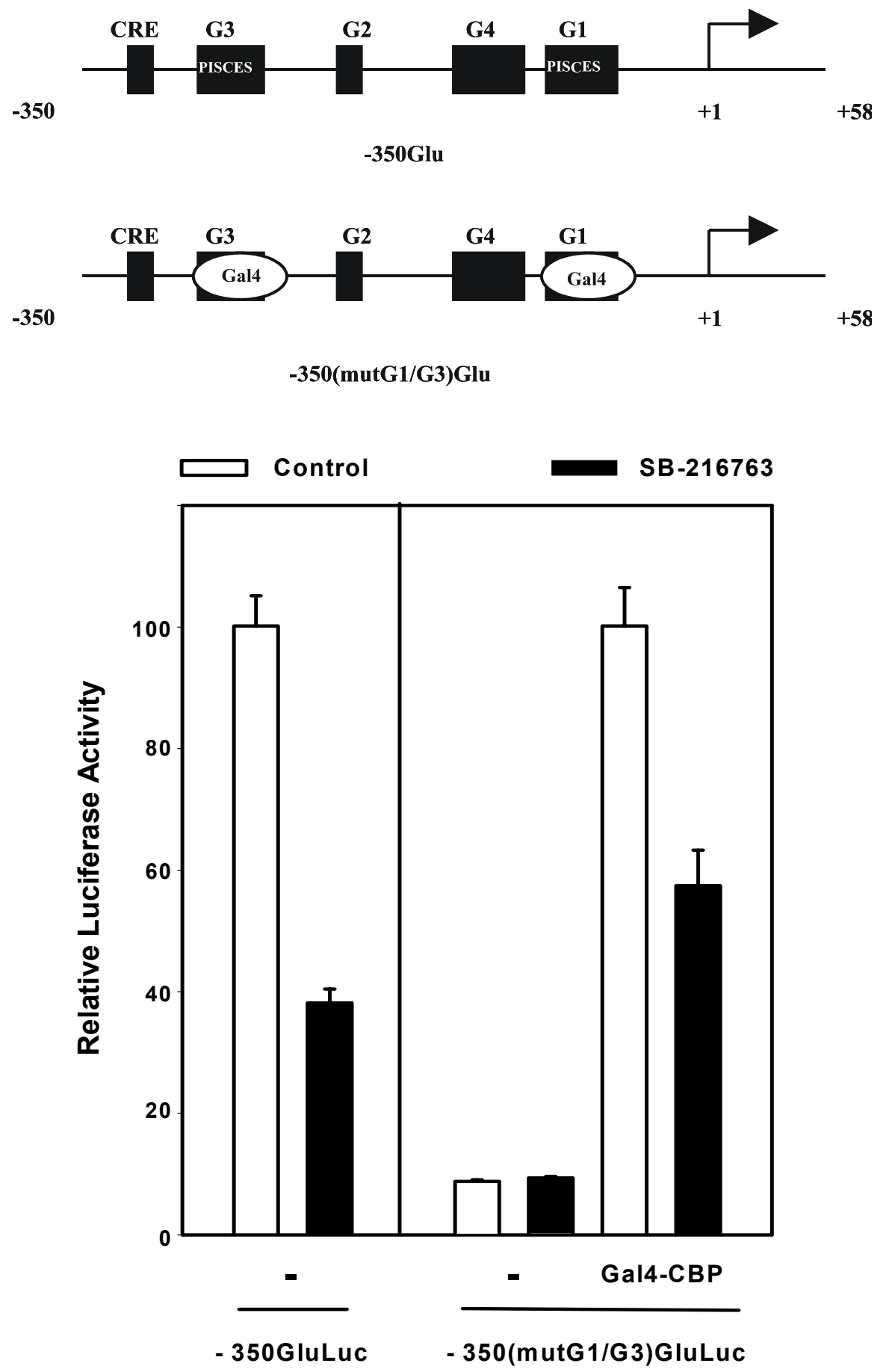

Fig. 23 Inhibition by SB-216763 of Gal4-CBP transcriptional activity

An expression vector encoding Gal4-CBP (3 $\mu \mathrm{g} / 6-\mathrm{cm}$ dish) was transfected into InR1G9 cells together with -350 (mutG1/G3)GluLuc $(2 \mu \mathrm{g} / 6-\mathrm{cm}$ dish) reporter gene and the cells were treated with the GSK3 inhibitor, SB-216763 $(30 \mu \mathrm{M})$ or received the solvent only (control). For comparison the $350 \mathrm{GluLuc}$ construct was also transfected. Luciferase activity is expressed as percentage of the mean value, in each experiment, of the activity measured in the Gal4-CBP or -350GluLuc controls respectively. Values are means $\pm \mathrm{SE}$ of three independent experiments, each in duplicate. On the upper panel, the scheme represents the wild type and the mutated glucagon reporter genes used. 


\section{7 Effect of GSK3 $\beta w t$ overexpression on the activity of Gal4-CBP}

\section{7. 1 Effect of GSK3 $\beta w$ t overexpression on Gal4-CBP activity in the context of the glucagon promoter}

To further characterize the effect of GSK3$\beta$ on the activity of CBP, full length CBP fused to Gal4-binding domain was transfected into InR1G9 cells together with the 350(mutG1/G3)GluLuc. Transfection of Gal4-CBP conferred strong basal activity to the mutated reporter gene, while overexpression of GSK3 $\beta w t$ resulted in a two-fold enhancement in transcriptional activity as shown in Fig.24, left panel. In contrast, when cotransfected with a reporter plasmid, in which multiple Gal4 binding sites had been placed in front of the truncated viral E1B promoter (5xGa14(E1B)Luc), Gal4-CBP conferred transcriptional activity, which was virtually unaffected by GSK3 $\beta w$ t overexpression (Fig.24, right panel).

\section{7. 2 Effect of GSK3 $\beta w t$ overexpression on the transcriptional activity conferred by $N$ - terminal and C-terminal part of $C B P$}

Because CBP is a huge multidomain protein (Glass and Rosenfeld, 2000), we employed the Gal4 system to map the effect of GSK3 $\beta$ on shorter responsive CBP fragments. In order to further characterize and localize any particular domain of CBP required to confer regulation of its transcriptional activity by GSK3 $\beta$ overexpression, several constructs were used, where the Gal4 DNA-binding domain was fused with different parts of CBP.

As a first approach, three constructs were used, where the Gal4 DNA-binding domain was fused to amino-terminal (amino acids 1-451), middle (amino acids 1062-1891) and carboxyterminal (amino acids 1892-2441) part of CBP (Kurokawa et al., 1998). When cotransfected with -350 (mutG1/G3)GluLuc, Gal4-CBP constructs containing full length (control) or Nand C-terminal parts of CBP conferred strong basal transcriptional activity, which was further enhanced by GSK3 $\beta w t$ overexpression by $200 \%, 155 \%$ and $171 \%$ respectively (Fig.25). In contrast, the middle part of CBP conferred relatively low activity, which was not affected by GSK3 $\beta$ overexpression (Fig.25).

\section{7. 3 Mapping the effect of GSK3 $\beta w$ t overexpression within the carboxy-terminal part of $C B P$}

To further map the effect of GSK3 $\beta$ wt overexpression on the C-terminal part of CBP, we used several deletion constructs all fused to Gal4, which were cotransfected in InR1G9 cells together with the -350 (mutG1/G3)GluLuc. When amino acids 1880 to 2441 and 2040 to 2441 were fused to Gal4, they conferred strong basal activity, which was further enhanced by GSK3 $\beta w t$ overexpression by $255 \%$ and $202 \%$ respectively (Fig.26). In contrast, when the Cterminal part of CBP was further shortened either at the carboxy - or the amino terminus to generate the constructs 2040-2170, 2306-2441 and 2171-2441, basal activity was dramatically diminished (Fig.26). Overexpression of GSK3 $\beta w t$ had no significant effect on the activity of 2306-2441 and 2171-2441, while in the case of 2040-2170 a moderate increase in the activity was observed that was not statistically significant. 

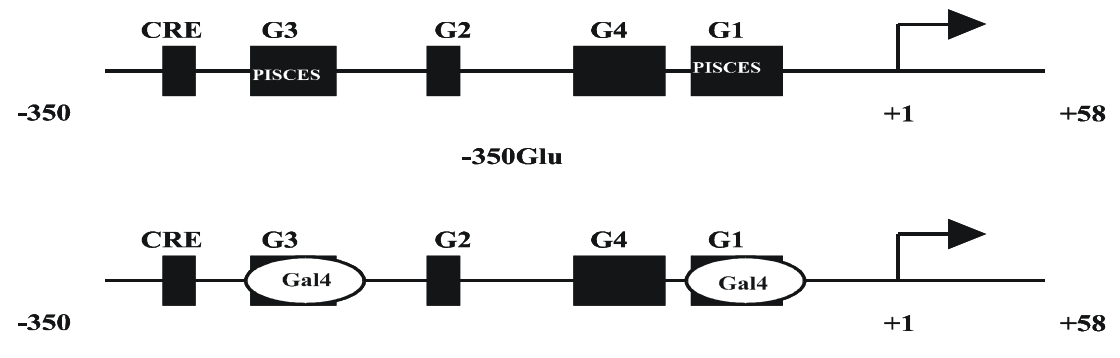

$-350($ mutG1/G3)Glu

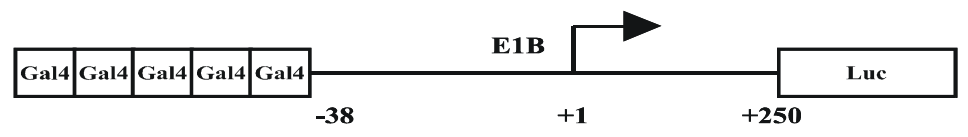

5xGal4(E1B)

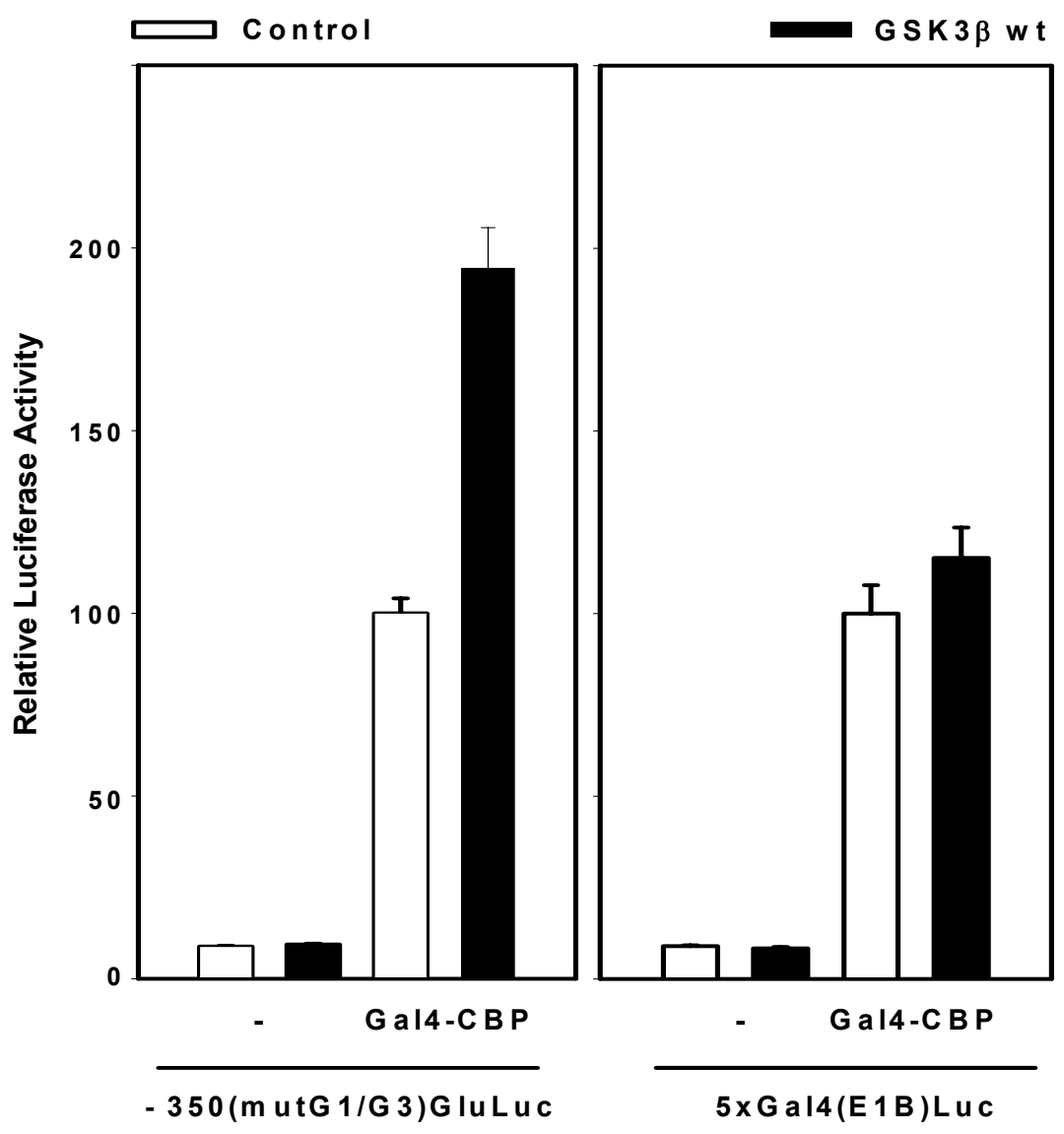

Fig. 24. Effect of GSK3 $\beta w t$ overexpression on Gal4-CBP activity in the context of the glucagon promoter

An expression vector encoding Gal4-CBP (pGal-CBP8, $3 \mu \mathrm{g} / 6-\mathrm{cm}$ dish) was transfected into InR1G9 cells together with -350 (mutG1/G3)GluLuc or 5xGal4(E1B)Luc $(2 \mu \mathrm{g} / 6-\mathrm{cm}$ dish respectively), with or without GSK3 $\beta \mathrm{wt}(3 \mu \mathrm{g} / 6-\mathrm{cm}$ dish). Luciferase activity is expressed as percentage of the mean value, in each experiment, of the activity measured in the respective Gal4-CBP control. Values are means \pm SE of three independent experiments, each done in triplicate. The constructs used are depicted on the upper panel. 


\begin{tabular}{|l|l|l|l|l|l|l|}
\hline KIX & HAT & C/H3 & & Q & \\
\hline
\end{tabular}

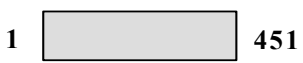

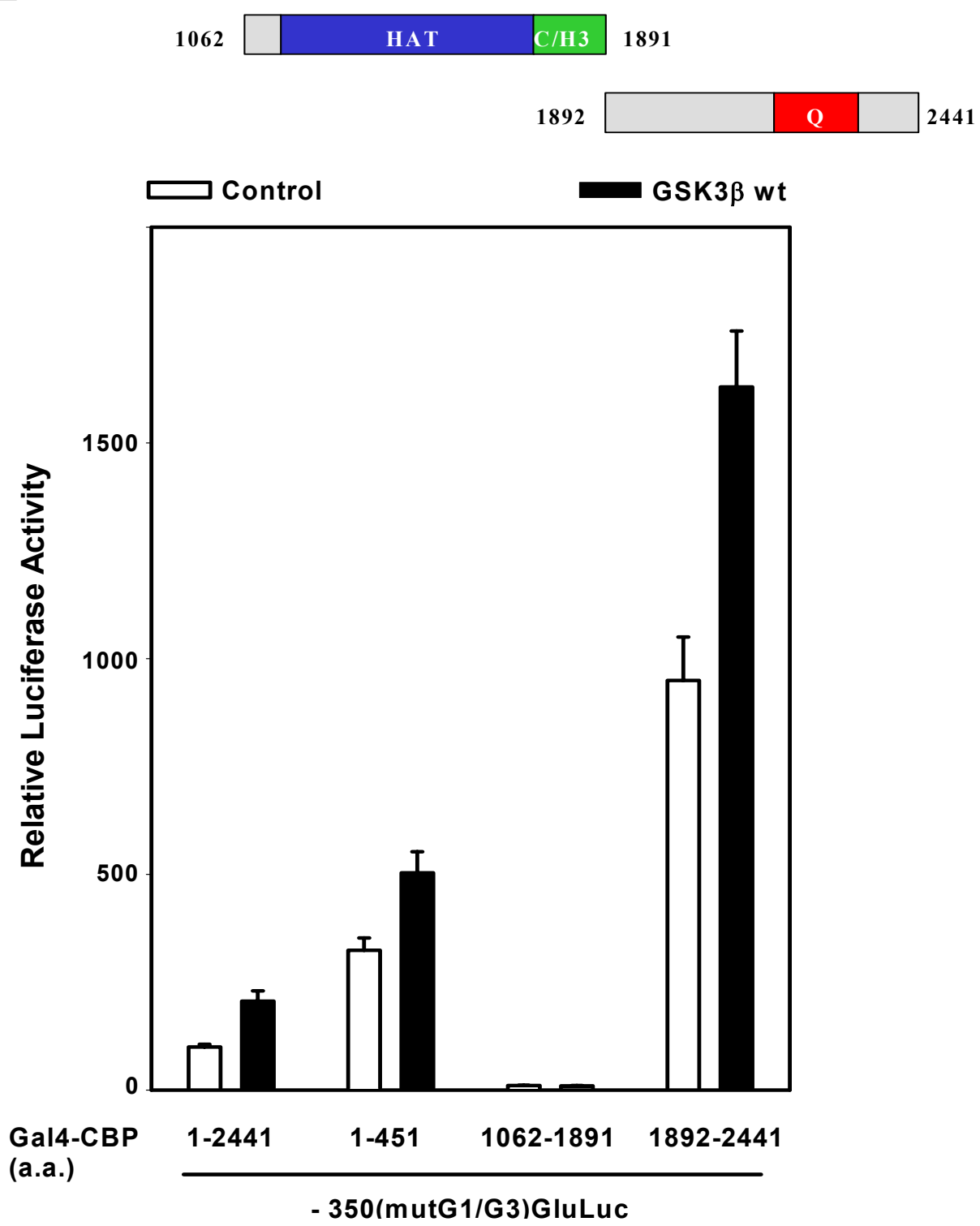

Fig. 25. Effect of GSK3 $\beta w t$ overexpression on the transcriptional activity conferred by Nterminal and C-terminal part of CBP

Expression vectors encoding Gal4-CBP fusion proteins $(3 \mu \mathrm{g} / 6-\mathrm{cm}$ dish) were transfected into InR1G9 cells together with -350 (mutG1/G3)GluLuc reporter gene $(2 \mu \mathrm{g} / 6-\mathrm{cm}$ dish) with or without GSK3 $3 w t(3 \mu \mathrm{g} / 6-\mathrm{cm}$ dish). The Gal4-CBP constructs are schematically depicted on top of the graph with indicated important functional domains and amino acid positions. Luciferase activity is expressed as percentage of the mean value, in each experiment, of the activity of 350(mutG1/G3)GluLuc plus Gal4-CBP full length. Values are means \pm SE of three independent experiments, each done in triplicate. KIX; CREB-interacting domain, C/H3; cystine/histidine-rich, HAT; histone acetyltransferase, Q; glutamine-rich, cofactor-interacting domain. 

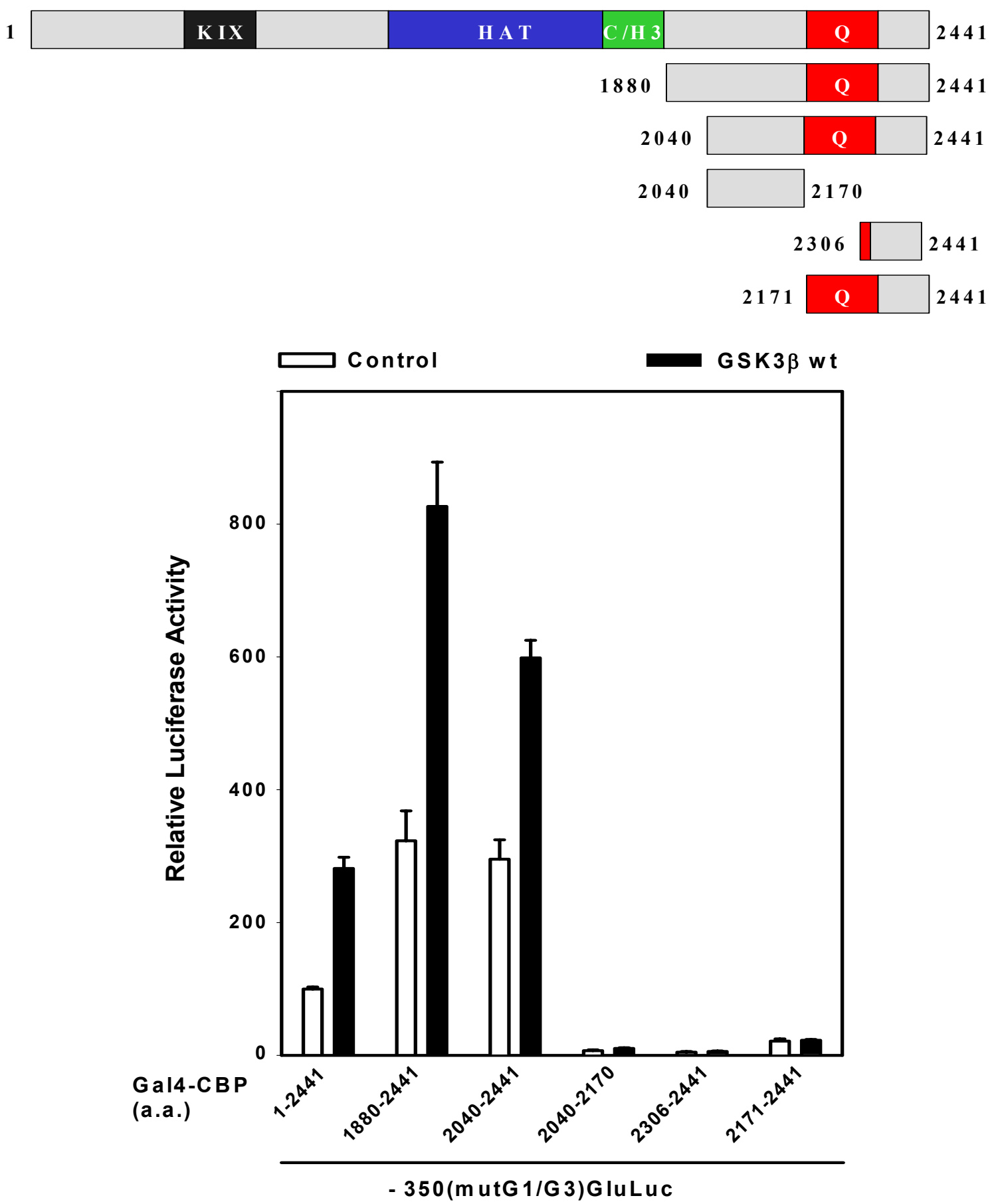

Fig. 26. Mapping the effect of GSK3 $\beta$ wt overexpression within the carboxy-terminal part of CBP

Expression vectors encoding Gal4-CBP fusion proteins $(3 \mu \mathrm{g} / 6-\mathrm{cm}$ dish) were transfected into InR1G9 cells together with -350(mutG1/G3)GluLuc reporter gene with or without GSK3bwt ( $3 \mu \mathrm{g} / 6$ $\mathrm{cm}$ dish). The Gal4-CBP constructs are schematically depicted on top of the graph with indicated important functional domains and amino acid positions. Luciferase activity is expressed as percentage of the mean value, in each experiment, of the activity of -350 (mutG1/G3)GluLuc plus Gal4-CBP full length. Values are means $\pm \mathrm{SE}$ of three independent experiments, each done in triplicate. $\mathrm{C} / \mathrm{H} 3$ : cystine/histidine-rich, HAT; histone acetyltransferase, Q; glutamine-rich, cofactor-interacting domain. 


\section{8 GSK3 $\beta$ mediated phosphorylation of Pax6 and CBP as revealed by in vitro assay}

Based on the above results, an in vitro assay was performed to examine whether GSK3 $\beta$ could phoshorylate Pax6 and CBP. Pax6 transactivation domain (TAD) (amino acids 299437, Mikkola et al., 1999) and a CBP fragment consisting of the amino acids 2040-2305 were fused to GST proteins, inducibly expressed in bacteria with IPTG and finally purified by glutathione, which was immobilized on cross-linked agarose beads. The purified GSTproteins were subsequently incubated first with whole cell lysates to substitute for any potential priming phosphorylation in a reaction mixture containing non-radioactively labelled ATP. GSK3 substrates often require a priming phosphorylation by another kinase in order to be phosphorylated efficiently by GSK3, although acidic amino acids close to the phosphoacceptor site could compensate for the negative charge provided by the phosphate group, which is required to stabilize the interaction between GSK3 and its substrates (Cohen and Frame, 2001). After extensive washing steps to remove the cell lysates and ATP, the GST-fusion proteins coupled to the agarose beads were incubated with active GSK3 $\beta$ (Upstate Biotechnology, USA) in the presence of radioactively labelled $\gamma$-ATP (Amersham Biosciences, UK). The proteins were loaded on a protein gel and stained with Coomassie (Fig.27A). After drying the gel, it was placed over a phosphorimager screen and proteins were analyzed for potential phosphorylation by GSK3 $\beta$ (Fig.27B).

\section{8. 1 Phosphorylation of Pax6 transactivation domain (TAD) by GSK3 $\beta$ in vitro}

GST-Pax6 (TAD) protein has an expected size of about $41 \mathrm{kDa}$ (Mikkola et al., 1999), which corresponds to the upper band shown in Fig.27A (lanes 2, 3 and 4), while the faster migrating band represents a C-terminally degraded product that is still fused to GST (Fig.27A, lanes 2, 3 and 4). Both of these protein fragments were phosphorylated, when GST-Pax6 (TAD) was incubated with GSK3 $\beta$ in the presence and in the absence of prior incubation with the cell lysates (Fig.27B, lanes 3 and 4 respectively, the bands pointed with the white arrow correspond to the respective fragments on the protein gel in Fig.27A). When the GST-Pax6 (TAD) was only incubated with cell lysates but not with GSK3 $\beta$, as in lane 2 in Fig.27B, there was no phosphorylation detected. This served as a control to exclude the possibility that any kinases of the lysates might be carried over by unspecific binding to the beads and phosphorylate the GST-fusion protein, when incubated with radioactively labelled ATP in the subsequent step. The phosphorylated protein, size of about $50 \mathrm{kDa}$, that appears in lanes 3 and 4 above the white arrow, comes apparently from an autophosphorylation reaction by GSK $3 \beta$, as revealed from lane 1 in Fig.27B (black arrow), where only GSK3 $\beta$ was added in the reaction mixture.

\section{8. 2 Phosphorylation of a C-terminal part of CBP consisting of amino acids 2040-2305 by} GSK3 $\beta$ in vitro

When a CBP fragment (aa 2040-2305) fused to GST, expected size of full-length protein about $56 \mathrm{kDa}$ (Fig.27A lanes 6, 7 and 8), was incubated with GSK3 $\beta$ in the absence of prior incubation with the cell lysates, it was phosphorylated, as revealed from lane 8 in Fig.27B (white arrow). However, this phosphorylation by GSK3 $\beta$ was attenuated in the presence of 
prior incubation with the cell lysates (Fig.27B, lane 7). When, on the other hand, the fusion protein was incubated only with cell lysates but not with GSK3 $\beta$ (similar as in lane 2), there was hardly any phosphorylation to be detected (Fig.27B, lane 6).

Again the phosphorylated protein, size of about $50 \mathrm{kDa}$, that appears in Fig.27B lanes 7 and 8 below the white arrow, comes apparently from an autophosphorylation reaction by GSK3 $\beta$. In Fig.27A lane 5, GST-CBP protein alone was loaded into a protein gel to help visualize the shorter degradation protein fragments that were not easily distinguishable in lanes 6,7 and 8 (Fig.27A). The faster migrating protein fragments are the result of degradation process by bacterial proteases during purification.

(A)

\section{GST-Pax6 (TAD) $\quad$ GST-CBP (aa 2040-2305)}

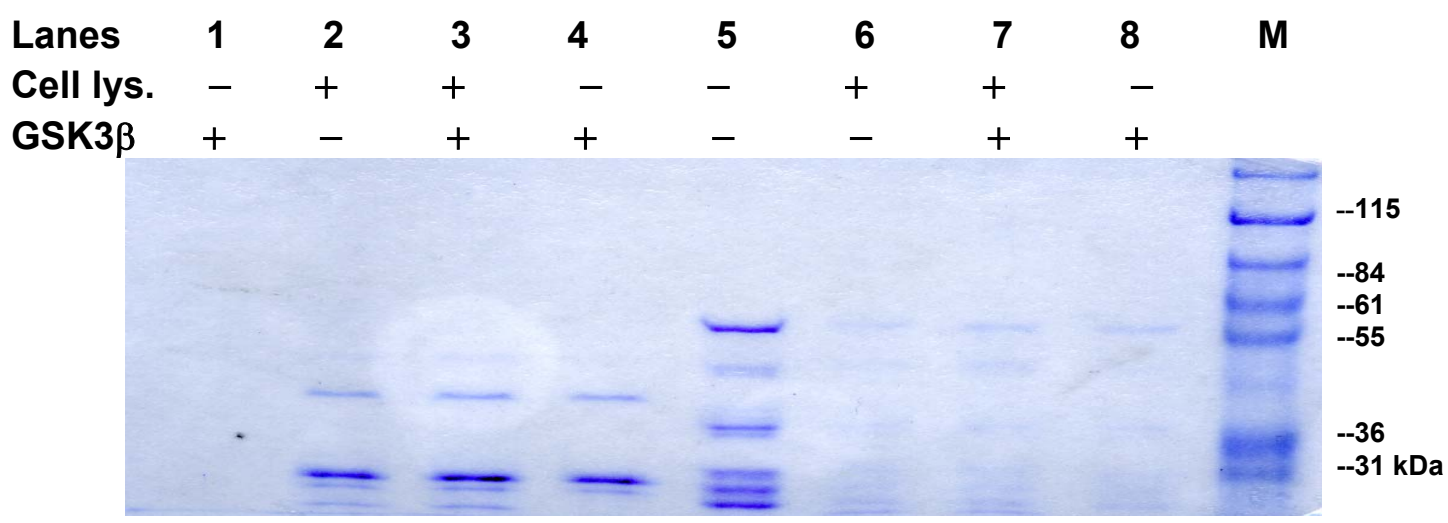

(B)

\section{GST-Pax6 (TAD) $\quad$ GST-CBP (aa 2040-2305)}

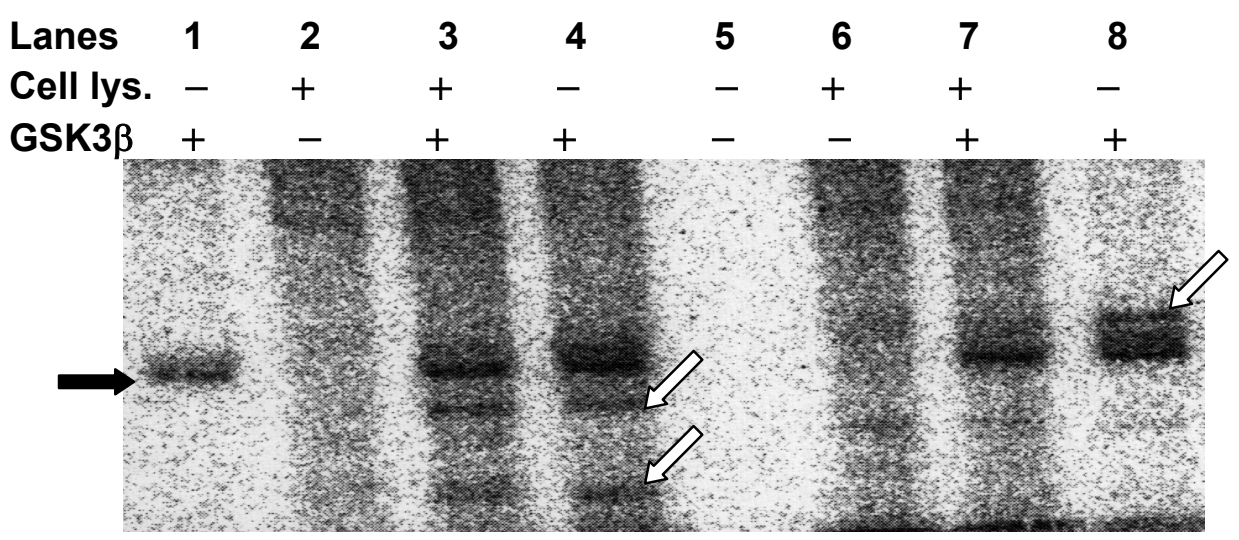

Fig. 27. Phosphorylation of Pax6 and CBP by GSK3 $\beta$ as revealed by in vitro assay

(A) Coomassie stained protein gel (10\%) of Pax6 (TAD) (aa 299-437, lanes 2, 3 and 4) and CBP (aa 2040-2305, lanes 5, 6, 7 and 8) that were fused to glutathione S-transferase. The GST-fusion proteins (3 $\mu \mathrm{g}$ ) in lanes 3, 4, 7 and 8 were incubated with GSK3 $\beta$ in a reaction mixture containing radioactively labelled ATP, while in lanes 2, 3, 6 and 7 they were preincubated with cell lysates with non-radioactively labelled ATP. (B) The gel was dried and placed on a phosphorimager screen. lane 1 ; GSK3 $\beta$ alone incubated with radioactively labelled ATP, M; protein marker. Results of a typical experiment out of four are shown. TAD; transactivation domain, GST; glutathione S-transferase. 


\subsection{Two-dimensional gel electrophoresis of nuclear proteins from InR1G9 cells}

Nuclear extracts were prepared as described in Materials and Methods (section 2.2.10) and in collaboration with Prof. Walther's laboratory (Greifswald, Germany) the proteins were loaded onto a 2D-gel and stained with Coomassie (Fig.28).

The principle behind this proteomic approach is to identify components of the insulin signalling pathway that reside in the nucleus and regulate glucagon gene transcription. Shortly, the idea would be to incubate with radioactivity the cells in vivo and then to treat them either with insulin or the GSK3 inhibitors or no treatment at all (control). Subsequently nuclear extracts would be prepared and separated by 2D-gel electrophoresis. The autoradiography should reveal phosphorylated proteins and these proteins, whose phosphorylation status would be regulated in an insulin and GSK3 dependent manner, would be further analyzed by mass spectrometry.

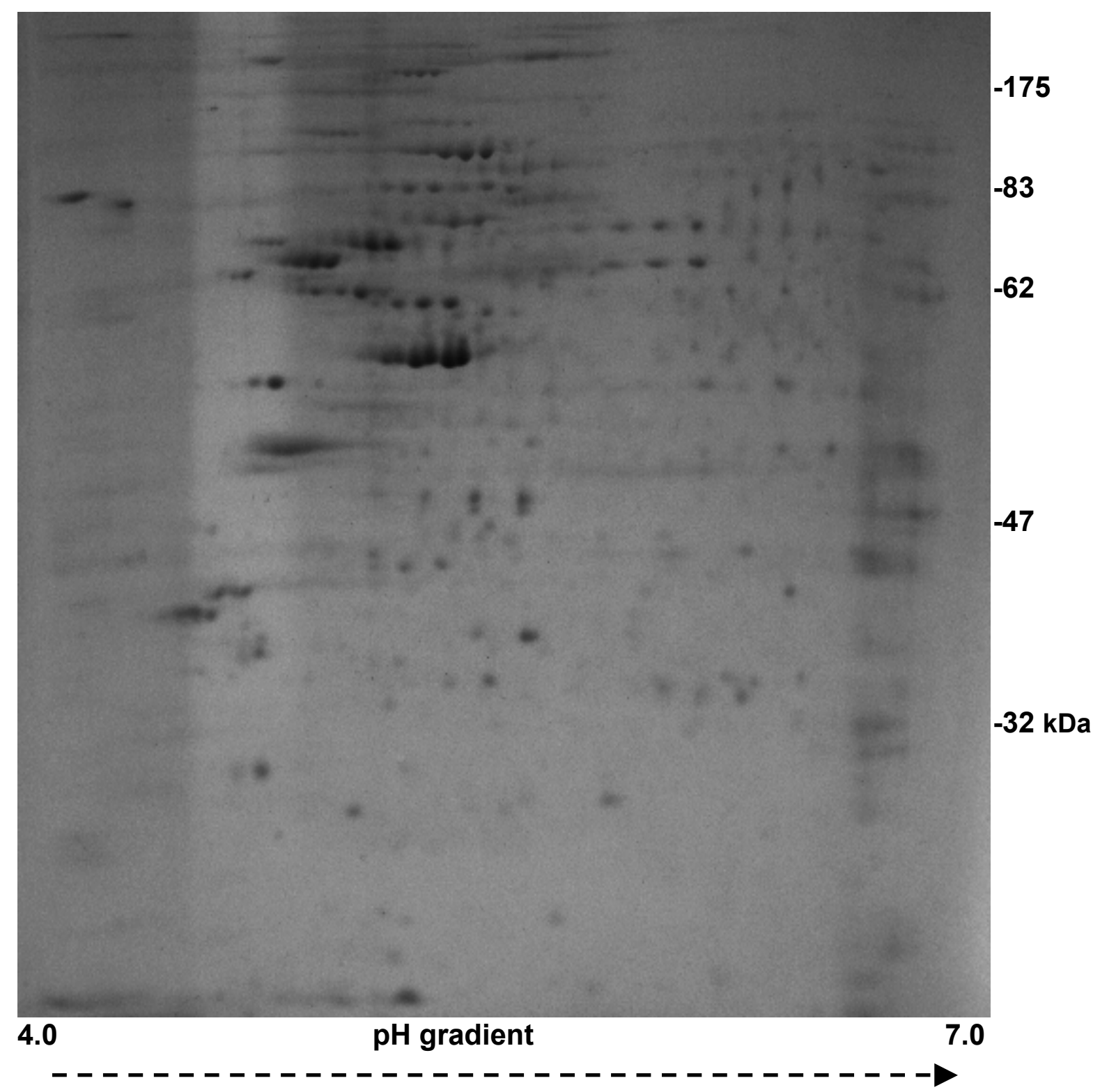


Fig. 28. Two dimensional gel electrophoresis of InR1G9 nuclear proteins

InR1G9 nuclear proteins (1 mg) were prepared as described in Materials and Methods (2. 2. 10) in lysis buffer, were applicated onto Immobiline DryStrips at $\mathrm{pH} 4.0-7.0$ and focused after their isoelectric points for approximately $48 \mathrm{~h}$. The $\mathrm{x}$-axis refers to gradient from $\mathrm{pH} 4.0$ on the left and $\mathrm{pH}$ 7.0 on the right hand side. The y-axis refers to the molecular weight of the proteins. As a protein standard a prestained protein marker (P7708, New England Biolabs) was used. The bands from top to bottom are : $175,83,62,47,32 \mathrm{kDa}$. The gel (12.5\%) was fixed in $12.5 \%$ TCA / 50\% methanol for at least $4 \mathrm{~h}$ and stained overnight with a Coomassie staining. 


\section{DISCUSSION}

One of the major targets of insulin, in addition to liver, muscle and adipose tissue, is the $\alpha$ cells in endocrine pancreas, where insulin binding to its receptor initiates a signalling cascade that results in inhibition of glucagon secretion and gene transcription. The significance of this regulation, which is important to control body's glucose homeostasis, becomes apparent in type 2 diabetes mellitus, where, apart from insulin deficiency and resistance, it is also characterized by hyperglucagonaemia contributing further to hyperglycaemia (Lefebvre, 1995). Therefore, understanding the molecular mechanism of inhibition of glucagon gene transcription by insulin can prove a potential target for the development of drugs to treat some of the aspects of type 2 diabetes.

In order to study the signal transduction pathway that leads to suppression of glucagon gene transcription by insulin, we used as a model a glucagon-producing tumor islet cell line, InR1G9, which shows many characteristic features of the mature $\alpha$-cells and is responsive to insulin as well (Takaki et al., 1986).

It has previously been shown that 350 base of the 5'-flanking region pairs of the glucagon gene are sufficient for negative regulation by insulin in InR1G9 cells (Philippe, 1989). Recent studies from our laboratory suggest that insulin-mediated inhibition is conferred through the PI(3)K/PKB pathway (Schinner et al., manuscript in preparation). In addition, a deletional analysis of the -350 region of the glucagon gene (Grzeskowiak et al., 2000) failed to identify a single insulin responsive element required and sufficient to confer the insulin responsiveness, as initially hypothesized (Philippe, 1991). However, it was suggested that the effect of insulin depends rather on the presence of both proximal promoter elements and more distal enhancer-like elements, with Pax6 playing a critical role in this interaction together with its potential coactivator CBP (Grzeskowiak et al., 2000).

In the present study a role for GSK3 $\beta$ was investigated in the regulation of glucagon gene transcription by insulin. Our results suggest that GSK3 might be the missing link downstream of PKB in response to insulin. Functional studies and in vitro kinase assay indicate that GSK $3 \beta$ regulates phosphorylation of Pax6 and CBP, although the significance of this finding in the context of the regulation of glucagon gene transcription needs to be shown in vivo. Finally, GSK3 inhibitors could mimick the effect of insulin on glucagon gene transcription.

\section{1 GSK3 expression in InR1G9 cells and inhibition of enzymatic activity by insulin- triggered phosphorylation}

Glycogen synthase kinase 3 was identified, over twenty years ago, as one of several kinases that phosphorylated and thus inactivated glycogen synthase. Northern blot analysis has shown that both isoforms of GSK3 are expressed ubiquitously (Woodgett, 1990). In addition, a genomic zoo blot (ranging from yeast to human) probed with rat GSK3 demonstrates that the kinase is also ubiquitously expressed throughout the animal kingdom (Plyte et al., 1992). 
Orthologues have also been found in plants exhibiting a remarkably identity over the catalytic domain. Consistent with these findings both isoforms of GSK3 are expressed in our model system as well. The enzymatic activity of GSK3 was also regulated in an insulindependent manner, as revealed by the immunoblot with phospho-specific antibodies after insulin treatment. GSK3 becomes phosphorylated at a serine residue at the amino terminus via $\mathrm{PKB}$ after insulin administration (Cross et al., 1995), which acts as a pseudosubstrate blocking its enzymatic activity (Dajani et al., 2001). The phosphorylation was a rapid event that occurred even after five minutes of insulin treatment and persisted over almost three hours, while it was attenuated at longer time periods. Reversible phosphorylation of proteins catalysed by protein kinases and protein phosphatases might represent the principal mechanism by which intracellular functions are regulated by extracellular signals.

Under resting conditions, there was hardly any phosphorylation detected, consistent with the notion that GSK3 is always active in the absence of any stimulus (Hughes et al., 1993). Although the physiological significance is not completely understood, phosphorylation at a tyrosine residue within the T-loop of the kinase domain might account for this property of GSK3. This T-loop phoshorylation is constitutive in unstimulated cells and appears to facilitate substrate phosphorylation without being strictly required for kinase activity (Dajani et al., 2001). The kinase responsible for tyrosine phosphorylation has not been identified in mammals yet, leaving open the possibility for an autocatalytic event (Wang et al., 1994).

\section{2 Regulation of glucagon gene transcription by GSK3 $\beta$}

Although GSK3 was ascribed its name based on the function known at the time of discovery, that is to regulate glycogen synthase, it is now known to exert a pleiotropic action. GSK3 has been implicated in fundamental processes including, besides metabolism, cell fate determination, apoptosis, oncogenesis, neurological disorders and transcriptional control (reviewed by Frame and Cohen, 2001, Grimes and Jope, 2001). Since there was evidence that insulin-mediated glucagon gene inhibition was conferred through the PI(3)K/PKB pathway, and GSK3 lies downstream of PKB in insulin signalling, a role for GSK3 was investigated. This study provides evidence that GSK3 $\beta$ is involved in the regulation of glucagon gene transcription and in its inhibition by insulin.

As a first approach, GSK3 $\beta$ was overexpressed. If GSK3 were involved in the regulation of glucagon gene transcription under resting conditions, it should contribute to basal activity. Therefore, by overexpressing GSK3 an increase in basal activity would be expected. This was, indeed, the case. Overexpression, by transient transfection, of rat GSK3 wild type resulted in a two fold enhancement, when compared to untransfected cells. The increase was due to enzymatic activity, because a kinase-dead mutant (GSK3 $\beta R 85)$, that cannot bind ATP any longer, had no effect at all.

As a next step, endogenous pools of GSK3 were assessed. For that reason seven chemically distinct compounds, that were recently developed by different sources as potent and selective GSK3 inhibitors, were used in cell culture experiments.. All of them reduced basal activity mimicking the effect of insulin on glucagon gene transcription, while they did not affect 
expression levels of another CMV promoter. Even if some of them inhibit, in addition to GSK3, other enzymes, the fact that inhibition of glucagon gene transcription was observed with all compounds tested indicates their insulin-mimetic action.

It seems that the maleimide compounds are more specific than the others, since they were tested against a panel of twenty-four kinases without significantly inhibiting any of them (Coghlan et al., 2000).

Noteworthy, the effect of lithium was neither synergistic nor additive to that of insulin on glucagon gene transcription, suggesting that insulin acts predominantly through GSK3 to confer inhibition.

To validate the effectiveness of the GSK3 inhibitors, several additional experiments were carried out. First, indirubin-3'-monoxime and alsterpaullone completely abolished the increase on glucagon gene transcription by overexpression of GSK3 $\beta$. Lithium acted in a similar manner, although it was less effective. Second, endogenous GSK3 activity was measured after treatment of cells with the compound, SB-216763. For that reason an in vitro kinase assay was performed on crude InR1G9 cell lysates. The specificity of the assay is derived from the substrate peptide, since recombinant GSK3 $\beta$ is able to phosphorylate only the prephosphorylated glycogen synthase peptide, and not a peptide that carries a mutation to a non-phosphorylable amino acid at the site where the prephosphorylation event takes place. Treatment with the GSK3 inhibitor, SB-216763, resulted in a significant inhibition of GSK3 activity at about $75 \%$.

Inhibition of endogenous GSK3 activity by the GSK3 inhibitors correlated with the modulation of its substrates, such as $\beta$-catenin, in vivo. Cells were treated with various compounds and levels of $\beta$-catenin were detected either by immunofluorescence studies or by immunoblot analysis. Phosphorylation of $\beta$-catenin by GSK3, in the context of the Wnt signalling pathway, is essential for its targeted degradation by the proteasome (Polakis, 2002). Inhibiting GSK3 results in stabilization and accumulation of the protein (Woodgett, 2001). Measuring the levels of $\beta$-catenin is a well established assay to monitor inhibition of GSK3 activity (Cross et al., 2001). Alternatively, phosphorylation of tau or measurement of glycogen synthesis can be performed (Coghlan et al., 2000). Treatment with either alsterpaullone or SB-415286 resulted in a significant increase in the levels of $\beta$-catenin in the cytosol, when compared to control. Under resting conditions, a weak staining for $\beta$-catenin was also observed in the cytosol, but it was very faint and after exposure of the cells to fluorescent light, they bleached very fast. Under three hours treatment with the GSK3 inhibitors, $\beta$-catenin did not seem to translocate into the nucleus, no colocalization with DAPI staining, in amounts that could be detected with this assay.

To quantify these results, InR1G9 cells were treated with the GSK3 inhibitors and extracts were prepared. Total cell lysates were loaded on a protein gel and were blotted against $\beta$ catenin. The same primary antibody was used as in the immunofluorescence experiment. Total $\beta$-catenin levels were two to three folds enhanced as compared to control. These findings are consistent with the current literature (Cross et al., 2001).

It is of interest to observe that insulin had no effect on $\beta$-catenin stabilization, consistent with the idea that GSK3 exists within two pools in cells, each of them being insulated from the 
other e.g. Wnt signalling does not result in glycogen synthesis and insulin does not induce accumulation of $\beta$-catenin, although both stimuli inhibit GSK3 activity (Ding et al., 2000).

Taken together these results suggest that GSK3 $\beta$ is involved in the regulation of glucagon gene transcription. These findings are consistent with recent studies implicating GSK3 in the regulation of gene expression. Lochhead et al. (2001) have shown that inhibition of GSK3 selectively reduced glucose-6-phosphatase and phosphoenolpyruvate carboxykinase gene expression. The expression of the above hepatic genes is dramatically altered in type 2 diabetes.

\section{3 GSK3 responsive element in the glucagon promoter}

Basal glucagon gene transcription seems to be conferred by a unique combinatorial and spatial arrangement of synergizing control elements and interacting proteins (Knepel, 2001). Using 5'-, 3'-, and internal deletion analysis a previous study failed to localize a single IRE in the glucagon gene 5'-flanking region (Grzeskowiak et al., 2000).

A similar approach was undertaken using, instead of insulin, the GSK3 inhibitor, SB-216763, with the aim to map a potential negative responsive element. SB-216763 efficiently inhibited transcription of the -292 GluLuc at a similar level to the -350 GluLuc, while the inhibitory effect was significantly abolished with further deletions that do not contain the PISCES motif in the G3 element. Using the reverse approach, shortening the promoter from the 3 '-end, SB216763 inhibited transcription only of the $-350 /-48$ GluLuc. Further deletions with reporter plasmids, that do not contain the PISCES motif in the G1 element, did not restore the suppression.

Taken together the results from the deletion analysis suggest that it does not seem to exist a single element in the glucagon promoter in response to the GSK3 inhibitor, SB-216763. The inhibitory effect of the compound was abolished when G3 was lost in the 5'-end deleted constructs, and when G1 was lost in the 3'-end deleted constructs, suggesting that Pax6 might be crucial, among other components that bind on the promoter, to confer responsiveness.

These findings are in contrast to some extent with a previous study by Grzeskowiak et al. (2000). Although insulin responsiveness rather required both proximal promoter and more distal enhancer-like elements, it was suggested that each of the glucagon gene enhancer-like elements were dispensable for the effect of insulin (Grzeskowiak et al., 2000). The reason for this inconsistency is not clear. It is possible that insulin signalling can target a wider spectrum of transcription factors on the glucagon promoter.

To further characterize the role of Pax6 to confer responsiveness to the GSK3 inhibitor, SB216763 , internal mutation analysis was performed by specifically abolishing binding only of Pax6 on the glucagon promoter (Andersen et al., 1999, Knepel et al., 1990). Although basal activity was largely reduced, mutating either G3A or G1 did not affect significantly neither the effect of insulin nor that of SB-216763. It is interesting to observe that both the maleimide compound and insulin elicited the same inhibitory effect on these reporter plasmids. The inhibitory effect of both substances was, however, abolished when both sites 
were mutated. Pax6 is a strong transactivator of glucagon gene expression under resting conditions, since mutation on both sites reduced basal activity more than $90 \%$.

These findings suggest that Pax6 is important for basal activity and for conferring insulin and SB-216763 responsiveness.

\section{4 GSK3 regulates transcriptional activity and phosphorylation of Pax6 in vitro}

To directly evaluate the effect of SB-216763 on Pax6 transcriptional activity, in the context of the glucagon promoter, the Gal4 system was employed. An expression vector encoding full length Pax6 fused to Gal4 when transfected together with the -350 (mutG1/G3)GluLuc raised the transcriptional activity dramatically, suggesting again that Pax6 is required for basal activity of glucagon promoter, and was responsive to inhibition by SB-216763 to a level similar of the wild type promoter, consistent with the effect of insulin on the same reporter gene (Grzeskowiak et al., 2000).

To test whether Pax 6 could be a substrate for GSK3 an in vitro assay was performed. There are examples of transcription factors, which are regulated by insulin activated pathways such as FKHR (Tang et al., 1999) and C/EBP $\alpha$ (Ross et al., 1999). GSK3 can phosphorylate many transcription factors (see Table 1 in Introduction), but Pax6 is not a known substrate. For that reason, the transactivation domain (TAD) of Pax6 was fused to GST protein. Recombinant GSK3 $\beta$ phosphorylated GST-Pax6 (TAD), both the full length fusion protein and a shorter C-terminally degraded fragment, which can prove useful in elucidating the phosphoacceptor residues. The GST-fusion protein was preincubated with cell lysates, since it has been reported that most of the GSK3 substrates require a priming phosphorylation located four amino acids C-terminally to the site of GSK3 phosphorylation (Fiol et al., 1987). This does not seem to be the case for Pax6, because GSK3 $\beta$ alone efficiently phosphorylated the TAD domain. Preincubation only with the cell lysates did not result in any phosphorylation at all of the GST-Pax6.

The sites phosphorylated by GSK $3 \beta$, as well as, the in vivo significance of this phosphorylation in the context of the regulation of glucagon gene transcription remains, however, to be further studied. It could be that phosphorylation affects transcriptional activity by promoting protein-protein interaction with other transcription factors or coactivators, as in the case of cAMP response element binding protein and its coactivator CBP (Chrivia et al., 1993, Kwok et al., 1994). DNA-binding of Pax6 might not be affected by GSK3 $\beta$-mediated phosphorylation of the transactivation domain, since insulin does not induce a change in the pattern of the bands or their intensity, as revealed by EMSA (Grzeskowiak, 2000a).

Pax6 seems to be active under resting conditions and no phosphorylation is known to be required for this property yet. It has been reported that the (TAD) domain of Pax6 is phosphorylated in vitro and in vivo in response to stimuli that activate the MAPK kinases. Although this phosphorylation stimulates the transactivatory properties of Pax6 (Mikkola et al., 1999), mutation of the phosphorylated sites did not affect the ability of insulin to inhibit Pax6 transcriptional activity in InR1G9 cells (Grzeskowiak, 2000a). 


\section{5 GSK3 regulates transcriptional activity and phosphorylation of CBP in vitro}

Results from a previous study (Grzeskowiak et al., 2000) raised the possibility that insulin might interfere with the function of a promoter-specific nucleoprotein coactivator complex, which integrates the activities of the transcription factors bound to the glucagon gene 5'flanking region with Pax6 being of particular importance. The C-terminal transactivation domain of Pax6 is rich in proline, serine and threonine residues and has been shown to interact with the coactivator p300/CBP (Hussain et al., 1999). Therefore, the Gal4 system was employed to test the effect of the GSK3 inhibitors on Gal4-CBP activity in the context of the glucagon promoter. The compound SB-216763 could inhibit the activity of the Gal4-CBP to a level similar of the wild type glucagon promoter. Similar results were obtained with insulin on the same reporter gene (Grzeskowiak et al., 2000). Besides responsiveness to the GSK3 inhibitor, Gal4-CBP could confer also strong basal activity.

The Gal4 system was further exploited to map the effect of GSK3 $\beta$ overexpression on the Gal4-CBP transcriptional activity. Overexpression of GSK3 $\beta w t$ resulted in a two fold enhancement in transcriptional activity of full length CBP fused to Gal4. The effect was only observed in the context of the glucagon promoter. The $\mathrm{N}$ - and C-terminal parts of CBP, when fused to Gal4, conferred strong basal activity and responsiveness to GSK3 overexpression, while the middle part was a very poor transactivator and no effect was observed. It seems that $\mathrm{N}$ - and C-terminal domains of CBP are sufficient to confer regulation by GSK3. These two domains can interact with many cofactors involved in the process of transactivation (reviewed by Shikama et al., 1997). Further deletions within the C-terminal part of CBP showed that amino acids between 2040 and 2441 are sufficient to respond to overexpression of GSK3. An effect was also seen, although of less magnitude, with the internal deletion 2040-2170, which contains the p/CIP interacting domain.

As a general observation, the degree of GSK3 responsiveness correlated with the levels of transcriptional activity of the various CBP fragments.

Based on these results, a CBP fragment containing the amino acids 2040-2305 was fused to GST and used in an in vitro assay together with recombinant GSK3 $\beta$. GSK3 $\beta$ phosphorylated GST-CBP (aa 2040-2305). However, this phosphorylation was significantly attenuated, when the GST-fusion protein was preincubated with cell lysates to provide any potential priming phosphorylation that might be required. A possible explanation could be that kinases in the cell lysates might recognize and phosphorylate the same residue with GSK3 $\beta$.

Analysis of the sequence of the C-terminal of CBP using a pattern search programme (CBS prediction server, developed by the Technical University of Denmark) for GSK3 consensus sites showed that a fragment between 2040 and 2170 might include indeed a consensus phosphorylation site for GSK3. These results provide further evidence that this fragment of $\mathrm{CBP}$, which interacts with the cofactor $\mathrm{p} / \mathrm{CIP}$ might play an important role in regulating gene transcription in insulin-induced pathway. Recently $\mathrm{p} / \mathrm{CIP}$ has been shown to modulate the CBP acetyltransferase activity in a substrate selective fashion, representing therefore a mechanism for integration of diverse signalling pathways (Perissi et al., 1999). 
These findings suggest that CBP activity might be directly regulated by GSK3 $\beta$ mediated phosphorylation. CBP and the closely related protein p300 are modular proteins with multiple functional domains (Korzus et al., 1998, McManus and Hendzel 2001, Shikama et al., 1997), which can interact, in addition to Pax6, with other transcription factors bound to the glucagon promoter including the Beta2/E47/E12 basic helix-loop-helix proteins (Mutoh et al., 1998, Qiu et al., 1998), NFATp (Fürstenau et al., 1999, Garcia-Rodriguez and Rao 1998), Ets-like transcription factors (Fürstenau et al., 1997, Yang et al., 1998) and CREB (Knepel et al., 1990, Kwok et al., 1994).

CBP has been shown to be phosphorylated in response to stimuli such as calcium and insulin (Impey et al., 2002, Chawla et al., 1998, Hu et al., 1999, Nakajima et al., 1996) and its acetyltransferase activity, essential for transactivation (Martinez-Balbas et al., 1998), can be subject to regulation by signal transduction pathways (Janknecht and Nordheim, 1996, Nakajima et al., 1996).

\section{6 Final concept}

The results presented in this study suggest a role for GSK3 in insulin-mediated inhibition of glucagon gene transcription, with Pax6 and CBP being critical components in this regulation (Fig.29). They are in accordance with an IRE-independent mechanism for regulation of gene transcription by insulin (Leahy et al., 1999, Pierreux et al., 1998, Pierreux et al., 1999, Yeagley et al., 1998). In glucocorticoid-induced 6-phosphofructo-2-kinase (Pierreux et al., 1998, Pierreux et al., 1999) and in cAMP-induced phosphoenolpyruvate carboxykinase (PEPCK) gene transcription (Yeagley et al., 1998), it has been shown that in each case a combination of several DNA elements and interacting transcription factors are required for both full responsiveness to the respective stimulus and inhibition by insulin. This has led to the conclusion that the unique array of factors may be recognized by a specific coactivatornucleoprotein complex and that inhibition of gene transcription by insulin may result from the disruption of this higher order complex. In the case of the glucagon promoter, findings support this concept suggesting that Pax6 and its coactivator CBP might play an important role in this regulation (Grzeskowiak et al., 2000).

The present study supports this idea by providing evidence that Pax6 binding to both promoter (G1) and enhancer (G3) elements presents a crucial integrating factor required for inhibition in response to the GSK3 inhibitor, SB-216763. Moreover, GSK3 regulated the transcriptional activity of Pax6 and CBP, and directly phosphorylated both of them in vitro, while it is still unclear, whether other transcription factors or coactivators associated with the glucagon promoter, might serve as GSK3 substrates. Nevertheless, the significance of this phosphorylation in the regulation of the activity of both Pax6 and CBP in vivo, as well as, in the regulation of glucagon gene transcription remains to be clarified.

CBP is a well known integrator of diverse signal transduction pathways to the general transcription machinery and chromatin (Shikama et al., 1997). In addition to serving as molecular scaffold, CBP possesses intrinsic acetyltransferase activity, which is required for regulation of gene transcription and can be further modulated by interaction with specific 
cofactors, like p/CIP or p/CAF (Shikama et al., 1997, Perissi et al., 1999). Consistent, a recent study has proposed that insulin inhibits hepatic glucose production by utilizing a liverenriched transcriptional inhibitory protein to disrupt the association of CBP and RNA polymerase II with PEPCK promoter (Duong et al., 2002).

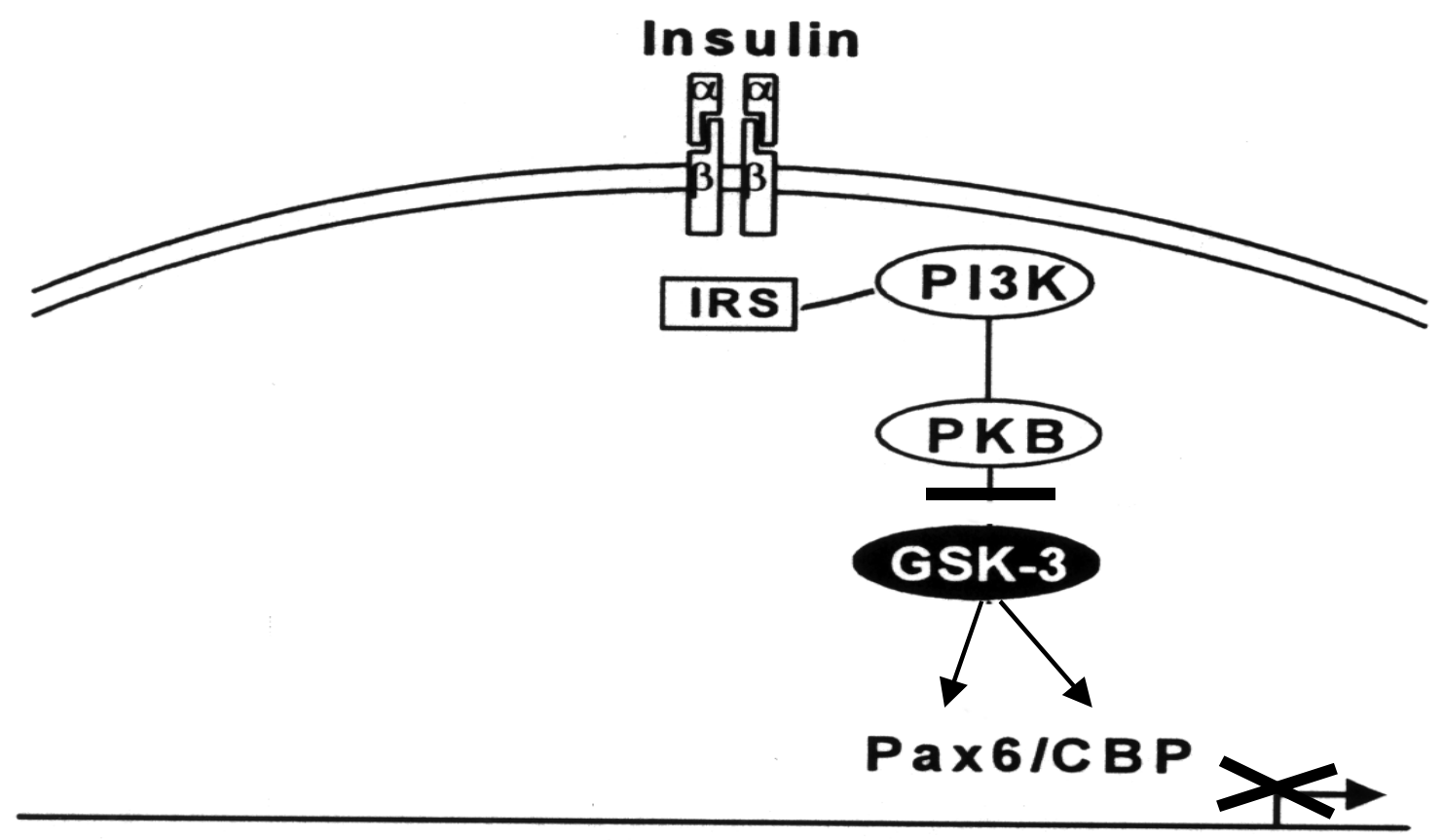

Glucagon gene

Fig. 29. Insulin inhibits glucagon gene transcription via the $\mathrm{PI}(3) \mathrm{K} / \mathrm{PKB} / \mathrm{GSK} 3$ pathway with Pax6 and CBP being critical components in this regulation

The above figure schematically represents the insulin induced signal transduction pathway that regulates glucagon gene transcription. Insulin, upon binding to its receptor, activates the PI(3)K/PKB pathway that phosphorylates and inhibits GSK3. This might likely result in the disruption of the nucleoprotein complex on the glucagon promoter. Critical components of this complex are Pax6 and its coactivator CBP. IRS; insulin receptor substrate, PI3K; phosphatidylinositol-3'-kinase, PKB; protein kinase B, GSK3; glycogen synthase kinase 3, CBP; CREB binding protein.

It is, therefore, likely to assume that within the specific context of the glucagon promoter a unique nucleoprotein complex is being induced, with Pax6 and CBP being critical components. In this view, insulin through inhibition of GSK3 might act on this glucagon promoter-specific protein complex by targeting Pax6 and CBP and maybe some other unidentified yet cofactors (Fig.29). In addition to the unique arrangement of the transcription factors bound to the glucagon promoter, the particular expression pattern of Pax6 contributes to the specificity of this regulation in the context of the pancreatic $\alpha$-cells.

The involvement of GSK3 in the regulation of glucagon gene transcription provides the link with the upstream kinases PI(3)K and PKB. The fact that it can directly phosphorylate Pax6 and CBP, although this needs to be confirmed in vivo, closes the gap between the signalling 
kinases induced by insulin and the nuclear proteins responsible for the regulation of glucagon gene expression. However, it is still possible that some other kinases might lie downstream of GSK3 in vivo. Consistent, the $\mathrm{PI}(3) \mathrm{K} / \mathrm{PKB} / \mathrm{GSK} 3$ pathway has been shown recently to regulate expression of gluconeogenic enzymes at the level of gene transcription as well. PEPCK and glucose 6-phosphatase genes are inhibited in response to insulin through GSK3 (Lochhead et al., 2001).

\section{7 Perspectives}

\section{7. 1 GSK3 inhibitors as novel antidiabetic drugs?}

The GSK3 inhibitors used in this study inhibited glucagon gene transcription. In another study, the maleimide compounds could inhibit gene expression of enzymes involved in gluconeogenesis (Lochhead et al., 2001), while CT-98023 has been shown to modulate muscle insulin resistance and glucose disposal in diabetic rodent models by selective inhibition of GSK3 (Ring et al., 2003, Cline et al., 2002). GSK3 could be, therefore, a therapeutical target against insulin resistance. Among other molecules associated with insulin resistance increased activity of the enzyme has been observed in diabetic mice (EldarFinkelman et al., 1999). Nevertheless, the specificity of the GSK3 inhibitors still awaits to be validated in most cases in vivo by animal and human clinical trials.

A major potential problem that could arise from the use of GSK3 inhibitors is connected with the broad range of functions of the enzyme and its ubiquitous expression. Inhibition of the enzyme by ATP-competitive GSK3 blockers, which do not discriminate between the different pools of the enzyme, could result in enhanced accumulation of $\beta$-catenin levels, which is a known oncogene (Polakis, 2002). To avoid such complications, drugs that selectively target non-axin-associated GSK3 would be desirable, especially for the treatment of chronic diseases, such as diabetes.

\section{7. 2 Studying insulin resistance in InR $1 G 9$ cells}

The knowledge of the insulin signalling pathway that regulates glucagon gene transcription can prove helpful as a model to study insulin resistance in pancreas. Type 2 diabetes is associated with hyperglucagonaemia, which contributes to hyperglycaemia (Knepel, 2001). It is hypothesized that hormones secreted by adipose tissue, such as TNF- $\alpha$ (Hotamisligil et al., 1996), adiponectin (Yamauchi et al., 2001), leptin (Halaas et al., 1995) and free fatty acids (Bergman et al., 2000) might play a role in insulin resistance. Therefore, it is interesting to examine whether these adipokines interfere with the regulation of glucagon gene transcription by insulin. The molecular mechanism of any potential interference can now be studied in more details. 


\section{REFERENCES}

Alessi DR and Cohen P (1998) Mechanism of activation and function of protein kinase B. Curr Opin Genet Dev 8: 55-62

Alexander-Bridges M, Mukhopadhyay NK, Jhala U, Denaro M, Kong XF, Avruch J, Maller J (1992) Growth factor-activated kinases phosphorylate IRE-ABP. Biochem Soc Trans 20: 691-693

Ali A, Hoeflich KP and Woodgett JR (2001) Glycogen synthase kinase-3 : properties, functions and regulation. Chemical Reviews 101: 2527-2540

Amit S, Hatzubai A, Birman Y, Andersen JS, Ben-Shushan E, Mann M, Ben-Neriah Y and Alkalay I (2002) Axin-mediated CKI phosphorylation of beta-catenin at Ser45: a molecular switch for the Wnt pathway. Genes Dev 16: 1066-1076

Andersen FG, Heller RS, Petersen HV, Jensen J, Madsen OD and Serup P (1999) Pax6 and $c d x-2 / 3$ form a functional complex on the rat glucagon gene promoter G1 element. FEBS Lett 445: 306-310

Armstrong JL, Bonavaud SM, Toole BJ and Yeaman SJ (2001) Regulation of glycogen synthesis by amino acids in cultured human muscle cells. J Biol Chem 276: 952-956

Bain J, McLauchlan H, Elliott $M$ and Cohen P (2003) The specificities of protein kinase inhibitors: an update. Biochem J 371: 199-204

Ballou LM, Tian PY, Lin HY, Jiang YP and Lin RZ (2001) Dual regulation of glycogen synthase kinase-3beta by the alpha1A-adrenergic receptor. J Biol Chem 276: 40910-40916

Barroso I and Santisteban P (1999) Insulin-induced early growth response gene (Egr-1) mediates a short term repression of rat malic enzyme gene transcription. J Biol Chem 274: 17997-18004

Beals CR, Sheridan CM, Turck CW, Gardner P and Crabtree GR (1997) Nuclear export of NT-ATc enhanced by glycogen synthase kinase-3. Science 275: 1930-1934

Bell GI and Polonsky KS (2001) Diabetes mellitus and genetically programmed defects in $\beta$ cell function. Nature 414: 788-791

Bergman RN, Ader M (2000) Free fatty acids and pathogenesis of type 2 diabetes mellitus. Trends Endocrinol Metab 11: 351-356

Boyle WJ, Smeal T, Defize LH, Angel P, Woodgett JR, Karin M and Hunter T (1991) Activation of protein kinase $\mathrm{C}$ decreases phosphorylation of c-Jun at sites that negatively regulate its DNA-binding activity. Cell 64: 573-584

Brady MJ, Bourbonais FJ and Saltiel AR (1998) The activation of glycogen synthase by insulin switches from kinase inhibition to phosphatase activation during adipogenesis in 3T3L1 cells. J Biol Chem 273: 14063-14066 
Brunet A, Bonni A, Zigmond MJ, Lin MZ, Juo P, Hu LS, Anderson MJ, Arden KC, Blenis J, and Greenberg ME (1999) Akt promotes cell survival by phosphorylating and inhibiting a forkhead transcription factor. Cell 96: 857-868

Burgering BMT and Coffer PJ (1995) Protein kinase B (c-Akt) in phosphatidylinositol-3OH kinase signal transduction. Nature 376: 599-602

Cantley LC (2002) The phosphoinositide 3-kinase pathway. Science 296: 1655-1657

Chapman SC, Ayala JE, Streeper RS, Culbert AA, Eaton EM, Svitek CA, Goldman J, Tavare JM and O' Brien RM (1999) Multiple promoter elements are required for the stimulatory effect of insulin on human collagenase-1 gene transcription. J Biol Chem 274: 18625- 18634

Chawla S, Hardingham GE, Quinn DR, Bading H (1998) CBP : A signal-regulated transcriptional coactivator controlled by nuclear calcium and CaM Kinase IV. Science 281: $1505-1509$

Cheatham B and Kahn R (1995) Insulin action and the insulin signalling network. Endocrine Reviews 16: 117-142

Chen G, Huang LD, Jiang YM and Manji HK (1999) The mood-stabilizing agent valproate inhibits the activity of glycogen synthase kinase-3. J Neurochem 72: 1327-1330

Chen L, Komiya I, Inman L, O' Neil J, Appel M, Alam T, Unger RH (1989) Effects of hypoglycaemia and prolonged fasting on insulin and glucagon gene expression. J Clin Invest 84: 711-714

Chrivia JC, Kwok RP, Lamb N, Hagiwara m, Montminy MR, Goodman RH (1993) Phosphorylated CREB binds specifically to the nuclear protein CBP. Nature 365: 855-859

Chu B, Soncin F, Price BD, Stevenson MA and Calderwood SK (1996) Sequential phosphorylation by mitogen-activated protein kinase and glycogen synthase kinase 3 represses transcriptional activation by heat shock factor-1. J Biol Chem 271: 30847-30857

Clement S, Krause U, Desmedt F, Tanti JF, Behrends J, Pesesse X, Sasaki T, Penninger J, Doherty M, Malaisse W, Dumont JE, Le Marchand-Brustel Y, Erneux C, Hue L and Schurmans S (2001) The lipid phosphatase SHIP2 controls insulin sensitivity. Nature 409: 92-97

Cline GW, Johnson K, Regittnig W, Perret P, Tozzo E, Xiao L, Damico C, and Shulman GI Effects of a novel glycogen synthase kinase-3 inhibitor on insulin-stimulated glucose metabolism in Zucker diabetic fatty $(f a / f a)$ rats. Diabetes 51: 2903-2910

Coghlan MP, Culbert AA, Cross DA, Corcoran SL, Yates JW, Pearce NJ, Rausch OL, Murphy GJ, Carter PS, Roxbee Cox L et al. (2000) Selective small molecule inhibitors of glycogen synthase kinase-3 modulate glycogen metabolism and gene transcription. Chem Biol 7: 793-803

Cohen P, Alessi DR, Cross DAE (1997) PDK1, one of the missing links in insulin signal transduction? FEBS Letters 410: 3-10 
Cohen P and Frame S (2001) The renaissance of GSK3. Nat Rev Mol Cell Biol 2: 769-776

Cross DA, Culbert AA, Chalmers KA, Facci L, Skaper SD and Reith AD (2001) Selective small-molecule inhibitors of glycogen synthase kinase-3 activity protect primary neurones from death. $J$ Neurochem 77: 94-102

Cross DAE, Alessi DR, Cohen P, Andjelkovich M and Hemmings BA (1995) Inhibition of glycogen synthase kinase-3 by insulin mediated by protein kinase B. Nature 378: 785-789

Dajani R, Fraser E, Roe SM, Young N, Good V, Dale TC and Pearl LH (2001) Crystal structure of glycogen synthase kinase 3 beta: structural basis for phosphate-primed substrate specificity and autoinhibition. Cell 105: 721-732

Datta SR, Brunet A and Greenberg ME (1999) Cellular survival : a play in three Akts. Genes Dev 13: 2905- 2927

Dent P, Campbell DG, Hubbard MJ and Cohen P (1989) Multisite phosphorylation of the glycogen-binding subunit of protein phosphatase-1G by cyclic AMP-dependent protein kinase and glycogen synthase kinase-3. FEBS Lett 248: 67-72

De Sarno P, Li W, Jope RS (2002) Regulation of Akt and glycogen synthase kinase-3 $\beta$ phosphorylation by sodium valproate and lithium. Neuropharmacology 43: 1158-1164

Diehl JA, Cheng M, Roussel MF and Sherr CJ (1998) Glycogen synthase kinase-3beta regulaes cyclin D1 proteolysis and subcellular localization. Genes Dev 12: 3499-3511

Ding VW, Chen RH and McCormick F (2000) Differential regulation of glycogen synthase kinase 3 beta by insulin and Wnt signalling. J Biol Chem 275: 32475-32481

Doble BW and Woodgett JR (2003) GSK-3: tricks of the trade for a multi-tasking kinase. $J$ Cell Sci 116: 1175-1186

Dominguez I, Itoh K, and Sokol SY (1995) Role of glycogen synthase kinase $3 \beta$ as a negative regulator of dorsoventral axis formation in Xenopus embryos. Proc Natl Acad Sci USA 92: 8498-8502

Dominquez I and Green BA (2001) Missing links in GSK3 regulation. Dev Biol 235: 303313

Downward J (1998) Mechanisms and consequences of activation of protein kinase B/Akt. Curr Opin Cell Biol 10: 262-267

Drucker DJ (1998) Glucagon-like peptides. Diabetes 47: 159-169

Drucker DJ, Philippe J, Jepeal L, Habener JF (1987) Glucagon gene 5' -flanking sequences promote islet cell-specific gene transcription. J Biol Chem 262: 15659-15665

Dumonteil E, Magnan C, Ritz-Laser B, Meda P, Dussoix P, Gilbert M, Ktorza A, Philippe J (1998) Insulin, but not glucose lowering corrects the hyperglucagonemia and increased proglucagon messenger ribonucleic acid levels observed in insulinopenic diabetes. Endocrinology 139: 4540-4546 
Duong DT, Waltner-Law ME, Sears R, Sealy L, Granner DK (2002) Insulin inhibits hepatocellular glucose production by utilizing liver-enriched transcriptional inhibitory protein to disrupt the association of CREB-binding protein and RNA polymerase II with the phosphoenolpyruvate carboxykinase gene promoter. J Biol Chem 277: 32234-32242

Durham SK, Suwanichkul A, Scheimann AO, Yee D, Jackson JG, Barr FG and Powell DR (1999) FKHR binds the insulin response element in the insulin-like growth factor binding protein-1 promoter. Endocrinology 140: $3140-3146$

Efrat S, Teitelman G, Anwar M, Ruggiero D, Hanahan D (1988) Glucagon gene regulatory region directs oncoprotein expression to neurones and pancreatic $\alpha$-cells. Neuron 1: $605-613$

Eldar-Finkelman H (2002) Glycogen synthase kinase 3: an emerging therapeutic target. TrendsMol Med 8: 126-132

Eldar-Finkelman H and Krebs EG (1997) Phosphorylation of insulin receptor substrate 1 by glycogen synthase kinase 3 impairs insulin action. Proc Natl Acad Sci USA 94: 9660-9664

Eldar-Finkelman H, Schreyer SA, Shinohara MM, LeBoeuf RC, and Krebs EG (1999) Increased glycogen synthase kinase-3 activity in diabetes- and obesity-prone C57BL/6 J mice. Diabetes 48: 1662-1666

Fagoto F, Jho E, Zeng L, Kurth T, Joos T, Kaufmann C, and Constantini F (1999) Domains of axin involved in protein-protein interactions, Wnt pathway inhibition and intracellular localization. J Cell Biol 145: 741-756

Fang X, Yu SX, Lu Y, Bast RCJr, Woodgett JR and Millis GB (2000) Phosphorylation and inactivation of glycogen synthase kinase 3 by protein kinase A. Proc Natl Acad Sci USA 97: 11960-11965

Fiol CJ, Mahrenholz AM, Wang Y, Roeske RW and Roach PJ (1987) Formation of protein kinase recognition sites by covalent modification of the substrate. Molecular mechanism for the synergistic action of casein kinase II and glycogen synthase kinase 3. $J$ Biol Chem 262: 14042-14048

Fiol CJ, Haseman JH, Wang YH, Roach PJ, Roeske RW, Kowalczuk M and DePaoliRoach AA (1988) Phosphoserine as a recognition determinant for glycogen synthase kinase-3 : phosphorylation of a synthetic peptide based on the G-component of protein phosphatase-1. Arch Biochem Biophys 267: 797-802

Forlenza OV, Spink JM, Dayanandan R, Anderton BH, Olesen OF and Lovestone S (2000) Muscarinic agonists reduce tau phosphorylation in non-neuronal cells via GSK-3beta inhibition and in neurons. J Neural Transm 107: 1201-1212

Frame S and Cohen $\mathbf{P}$ (2001) GSK3 takes centre stage more than 20 years after its discovery. Biochem J 359: 1-16

Frame S, Cohen P and Biondi RM (2001) A common phosphate binding site explains the unique substrate specificity of GSK3 and its inactivation by phosphorylation. Mol Cell 7: $1321-1327$ 
Fürstenau U, Schwaninger M, Blumer R, Kennerknecht I and Knepel W (1997) Characterization of a novel protein kinase $\mathrm{C}$ response element in the glucagon gene. Mol Cell Biol 17: 1805-1816

Fürstenau U, Schwaninger M, Blume R, Jendrusch EM, Knepel W (1999) Characterization of a novel calcium response element in the glucagon gene. J Biol Chem 274: $5851-5860$

Garcia-Perez J, Avila J, Diaz-Nido J (1998) Implication of cyclin-dependent kinases and glycogen synthase kinase 3 in the phosphorylation of microtubule-associated protein $1 \mathrm{~B}$ in developing neuronal cells. J Neurosci Res 52: 445-452

Garcia-Rodriguez C and Rao A (1998) Nuclear factor of activated T cells (NFAT)dependent transactivation regulated by the coactivators p300/CREB-binding protein (CBP). $J$ Exp Med 187: 2031-2036

Glass CK and Rosenfeld MG (2000) The coregulator exchange in transcriptional functions of nuclear receptors. Genes Dev 14: 121-141

Grimes CA and Jope RS (2001) The multifaceted roles of glycogen synthase kinase $3 \beta$ in cellular signalling. Prog Neurobiol 65: 391-426

Grimes CA and Jope RS (2001) CREB activity is inhibited by glycogen synthase kinase-3 $\beta$ and facilitated by lithium. $J$ Neurochem 78: 1219-1232

Grzeskowiak R, Amin J, Oetjen E, Knepel W. (2000) Insulin responsiveness of the glucagon gene conferred by interactions between proximal promoter and more distal enhancer-like elements involving the paired-domain transcription factor Pax6. J Biol Chem 275: 30037-30045

Grzeskowiak R (2000a) Involvement of the paired-domain transcription factor Pax6 in the regulation of glucagon gene transcription by insulin. PhD Dissertation

Habener JF, Drucker DJ, Mojsov S, Knepel W, Philippe J (1991) Biosynthesis of glucagon. In: Samols E, ed. The endocrine pancreas. New York: Raven Press, 53-71

Halaas JL, Gajiwala KS, Maffei M, Cohen SL, Chait BT, Rabinowitz D, Lallone RL, Burley SK, Friedman JM (1995) Weight-reducing effects of the plasma protein encoded by the obese gene. Science 269: 543-546

Hanger DP, Hughes K, Woodgett JR, Brion JP and Anderton BH (1992) Glycogen synthase kinase-3 induces Alzheimer's disease-like phosphorylation of tau : generation of paired helical filament epitopes and neuronal localization of the kinase. Neurosci Lett 147: $58-62$

Harris MI, Flegel KM, Cowie CC, Eberhart MS, Goldstein DE, Little RR, Wiedmeyer HM, Byrd-Holt DD (1998) Prevalence of diabetes, impaired fasting glucose, and impaired glucose tolerance in US adults. Diabetes Care 21: 518-524

Hartigan JA, Xiong WC and Johnson GV (2001) Glycogen synthase kinase 3beta is tyrosine phosphorylated by PYK2. Biochem Biophys Res Commun 284: 485-489 
Harwood AJ (2001) Regulation of GSK3: a cellular multiprocessor. Cell 105: 821-824

Herzig S, Füzesi L and Knepel W (2000) Heterodimeric Pbx-Prep1 homeodomain protein binding to the glucagon gene restricting transcription in a cell type-dependent manner. $J$ Biol Chem 275: 27989-27999

Hoeflich KP, Luo J, Rubie EA, Tsao MS, Jin O and Woodgett JR (2000) Requirement for glycogen synthase kinase-3beta in cell survival and NF-kappaB activation. Nature 406: 86-90

Hotamisligil GS, Peraldi P, Budavari A, Ellis R, White MF, Spiegelman BM (1996) IRS1-mediated inhibition of insulin receptor tyrosine kinase activity in TNF-alpha- and obesityinduced insulin resistance. Science 271: 665-668

Hu SC, Chrivia J and Ghosh A (1999) Regulation of CBP-mediated transcription by neuronal calcium signalling. Neuron 22: 799-808

Hughes K, Ramakrishna S, Benjamin WB and Woodgett JR (1992) Identification of multifunctional ATP-citrate lyase kinase as the alpha-isoform of glycogen synthase kinase-3. Biochem J 288: 309-314

Hughes K, Nikolakaki E, Plyte SE, Totty NF and Woodgett JR (1993) Modulation of the glycogen synthase kinase-3 family by tyrosine phosphorylation. EMBO J 12: 803-808

Hussain MA, Lee J, Miller CP and Habener JF (1997) POU domain transcription factor brain 4 confers pancreatic alpha-cell-specific expression of the proglucagon gene through interaction with a novel proximal promoter G1 element. Mol Cell Biol 17: 7186-7194

Hussain MA and Habener JF (1999) Glucagon gene transcription activation mediated by synergistic interactions of Pax6 and cdx-2/3 with the p300 co-activator. J Biol Chem 274: 28950-28957

Ikeda S, Kishida S, Yamamoto H, Murai H, Koyama S and Kikuchi A (1998) Axin, a negative regulator of the Wnt signalling pathway, forms a complex with GSK-3beta and betacatenin and promotes GSK-3beta-dependent phosphorylation of beta-catenin. EMBO J 17: $1371-1384$

Ilouz R, Kaidanovich O, Gurwitz D and Eldar-Finkelman H (2002) Inhibition of glycogen synthase kinase-3beta by bivalent zinc ions : insight into the insulin-mimetic action of zinc. Biochem Biophys Res Commun 295: 102-106

Impey S, Fong AL, Wang Y, Cardinaux JR, Fass DM, Obrietan k, Wayman GA, Storm DR, Soderling TR, and Goodman RH (2002) Phosphorylation of CBP mediates transcriptional activation by neural activity and CaM kinase IV. Neuron 34: 235-244

James R, Erier T and Kazenwadel J (1994) Structure of the murine homeobox gene cdx-2 : expression in embryonic and adult intestinal epithelium. J Biol Chem 269: 15229-15237

Janknecht R and Nordheim A (1993) Gene regulation by ets proteins. Slochim Biophys Acta 1155: $346-356$ 
Janknecht $\mathbf{R}$ and Nordheim A (1996) MAP kinase-dependent transcriptional coactivation by Elk-1 and its cofactor CBP. Biochem Biophys Res Commun 228: 831-837

Jho E, Lomvardas S and Constantini F (1999) A GSK3beta phosphorylation site in axin modulates interaction with beta-catenin and Tcf-mediated gene expression. Biochem Biophys Res Commun 266: 28-35

Jiang G, Zhang BB (2003) Glucagon and regulation of glucose metabolism. Am J Physiol Endocrinol Metab 284(4): E671-678

Jin T and Drucker DJ (1996) Activation of proglucagon gene transcription through a novel promoter element by the caudal-related homeodomain protein cdx-2/3. Mol Cell Biol 16: 1928

Jope RS and Bijur GN (2002) Mood stabilizers, glycogen synthase kinase $3 \beta$ and cell survival. Mol Psych 7: 35-45

Kaufmann E and Knöchel W (1996) Five years on the wings of fork head. Mech Dev 57: 320

Kaytor MD and Orr HT (2002) The GSK3 $\beta$ signalling cascade and neurodegenerative disease. Curr Opin Neurobiol 12: 275-278

Kellerer M, Lammers R, Häring HU (1999) Insulin signal transduction : possible mechanisms for insulin resistance. Exp Clin Endocrinol Diabetes 107: 97-106

Kirschenbaum F, Hsu SC, Cordell B and McCarthy JV (2001) Glycogen synthase kinase3beta regulates presenilin 1 C-terminal fragment levels. J Biol Chem 276: 30701-30707

Klein PS and Melton DA (1996) A molecular mechanism for the effect of lithium on development. Proc Natl Acad Sci USA 93: 8455-8459

Knepel W, Chafitz J and Habener JF (1990a) Transcriptional activation of the rat glucagon gene by the cyclic AMP-responsive element in pancreatic islet cells. Mol Cell Biol 10: 67996804

Knepel W, Jepeal L, and Habener JF (1990b) A pancreatic islet cell-specific enhancer-like element in the glucagon gene contains two domains binding distinct cellular proteins. $J$ Biol Chem 265: 8725-8735

Knepel W, Vallejo M, Chafitz Ja, and Habener JF (1991) The pancreatic islet-specific glucagon G3 transcription factors recognize control elements in the rat somatostatin and insulin-I genes. Mol Endocrinol 5: 1457-1466

Knepel W (1993) Transcriptional control of pancreatic islet hormones gene expression. Exp Clin Endocrinol 101: 39-45

Knepel W (2001) Chapter 5 : The $\alpha$-cell and regulation of glucagon gene transcription. From the textbook of Habener Jf, Hussain MA "Molecular basis of pancreas development and function" Kluwer Academic Publishers 
Korzus E, Torchia J, Rose DW, Xu L, Kurokawa R, McInerney EM, Mullen TM, Glass CK and Rosenfeld MG (1998) Transcription factor-specific requirements for coactivators and their acetyltransferase functions. Science 279: 703-707

Krueger M, Schwaninger M, Blume R, Oetjen E and Knepel W (1997) Inhibition of CREB and cAMP response element-mediated gene transcription by the immunosuppressive drugs cyclosporine A and FK506 in T cells. Naunyn-Schmiedberg's Arch Pharmacol 356: 433-440

Kruse F, Rose SD, Swift GH, Hammer RE and MacDonald RJ (1993) An endocrinespecific element is an integral component of an exocrine-specific pancreatic enhancer. Genes Dev 7: 774-786

Kuhne MR, Zhao Z, Rowles J, Lavan BE, Shen SH, Fischer EH, Lienhard GE (1994) Dephosphorylation of insulin receptor substrate 1 by the tyrosine phosphatase PTP2C. J Biol Chem 269: 15833-15837

Kurokawa R, Kalafus D, Oligastro MH, Kioussi C, Xu L, Torcha J, Rosenfeld MG, Glass CK (1998) Differential use of CREB binding protein-coactivator complexes. Science 279: $700-703$

Kwok RPS, Lundblad JR, Chrivia JC, Richards JP, Bächinger HP, Brennan RG, Roberts SGE, Green MR and Goodman RH (1994) Nuclear protein CBP is a coactivator for the transcription factor CREB. Nature 370: 223-226

Kyriakis JM, App H, Avruch J (1992) Raf-1 activates MAP kinase-kinase. Nature 358: 417-421

Laser B, Made P, Constant I and Philippe J (1996) The caudal-related homeodomain protein cdx-2/3 regulates glucagon gene expression in islet cells. $J$ Biol Chem 271: 2898428994

Lawlor MA and Alessi DR (2001) PKB/Akt : a key mediator of cell proliferation, survival and insulin responses? J Cell Sci 114: 2903-2910

Leahy P, Crawford DR, Grossmann G, Gronostajski RM and Hanson RW (1999) CREB binding protein coordinates the functin of multiple transcription factors including nuclear factor I to regulate phosphoenolpyruvate carboxykinase (GTP) gene transcription. $J$ Biol Chem 274: 8813-8822

Leclerc S, Garnier M, Hoessel R, Marko D, Bibb JA, Snyder GL, Greengard P, Biernat J, Wu YZ, Mandelkow EM et al. (2001) Indirubins inhibit glycogen synthase kinase-3 beta and CDK5/p25, two protein kinases involved in abnormal tau phosphorylation in Alzheimer's disease. A property common to most cyclin-dependent kinase inhibitors? J Biol Chem 276: 251-260

Lee YC, Asa SL, Drucker DJ (1992) Glucagon gene 5' -flanking sequences direct expression of simian virus 40 large $\mathrm{T}$ antigen to the intestine, producing carcinoma of the large bowel in transgenic mice. J Biol Chem 267: 10705-10708 
Leevers SJ, Vanhaesebroeck B and Waterfield MD (1999) Signalling through phosphoinositide 3-kinases : the lipids take centre stage. Curr Opin Cell Biol 11: 219-225

Lefebvre PJ (1995) Glucagon and its family revisited. Diabetes Care 18: 715-730

Leost M, Schultz C, Link A, Wu YZ, Biernat J, Mandelkow EM, Bibb JA, Snyder GL, Greengard P, Zaharevitz DW, Gussio R, Senderowicz AM, Sausvilee EA, Kunick C and Meijer L (2000) Paullones are potent inhibitors of glycogen synthase kinase-3 $\beta$ and cyclindependent kinase 5/p25. Eur J Biochem 267: 5983-5994

Lesort M, Jope RS and Johnson GV (1999) Insulin transiently increases tau phosphorylation: involvement of glycogen synthase kinase-3beta and Fyn tyrosine kinase. $J$ Neurochem 72: 576-584

Li Y, Bharti A, Chen D, Gong J and Kufe D (1998) Interaction of glycogen synthase kinase 3 beta with the DF3/MUC1 carcinoma-associated antigen and beta-catenin. Mol Cell Biol 18: 7216-7224

Liu C, Li Y, Semenov M, Han C, Baeg GH, Tan Y, Zhang Z, Lin X and He X (2002) Control of beta-catenin phosphorylation/degradation by a dual-kinase mechanism. Cell 108: $837-847$

Lochhead P, Coghlan M, Rice SQJ and Sutherland C (2001) Inhibition of GSK-3 selectively reduces glucose-6-phosphatase and phosphoenolpyruvate carboxykinase gene expression. Diabetes 50: 937-946

Maehama T, Dixon JE (1998) The tumor suppressor, PTEN/MMAC1, dephosphorylates the lipid second messenger, phosphatidylinositol 3,4,5-trisphosphate. J Biol Chem 273: 1337513378

Mansouri A, Hallonet M, Gruss P (1996) Pax genes and their roles in cell differentiation and development. Curr Opin Cell Biol 6: 851-857

Martinez A, Alonso M, Castro A, Perez C, Moreno FJ (2002) First non-ATP competitive glycogen synthase kinase 3 beta (GSK-3beta) inhibitors: thiadiazolidinones (TDZD) as potential drugs for the treatment of Alzheimer's disease. J Med Chem 45: 1292-1299

Martinez A, Castro A, Dorronsoro I, Alonso M (2002a) Glycogen synthase kinase 3 (GSK3) inhibitors as new promising drugs for diabetes, neurodegeneration, cancer and inflammation. Med Res Rev 22: 373-384

Martinez-Balbas MA, Bannister AJ, Martin k, Haus-Seuffert P, Meisterernst M, Kouzarides T (1998) The acetyltransferase activity of CBP stimulates transcription. EMBOJ 17: $2886-2893$

McManus KJ and Hendzel MJ (2001) CBP, a transcriptional coactivator and acetyltransferase. Biochem Cell Biol 79: 253-266

Meijer L, Thunnissen AM, White AW, Garnier M, Nikolic M, Tsai LH, Walter J, Cleverley KE, Salinas PC, Wu YZ et al. (2000) Inhibition of cyclin-dependent kinases, GSK-3beta and CKI by hymenialdisine, a marine sponge constituent. Chem Biol 7: 51-63 
Mettey Y, Gompel M, Thomas V, Garnier M, Leost M, Ceballos-Picot I, Noble M, Endicott J, Vierfond JM and Meijer L (2003) Aloisines, a new family of CDK/GSK-3 inhibitors. SAR study, crystal structure in complex with CDK2, enzyme selectivity and cellular effects. J Med Chem 46: 222-236

Meyer TE and Habener JF (1993) Cyclic adenosine 3', 5' - monophosphate response element binding protein (CREB) and related transcription-activating deoxyribonucleic acidbinding proteins. Endocrine Rev 14: 269-290

Mikkola I, Bruun JA, Bjorkoy G, Holm T and Johansen T (1999) Phosphorylation of the transactivation domain of Pax6 by extracellular signal-regulated kinase and p38 mitogenactivated protein kinase. J Biol Chem 274: 15115-15126

Morell C, Cordier-Bussat M, Philippe J (1995) The upstream promoter element of the glucagon gene, G1, confers alpha cell-specific expression. J Biol Chem 270: 3046-3055

Morisco C, Seta K, Hardt SE, Lee Y, Vatner SF and Sadoshima J (2001) Glycogen synthase kinase $3 \beta$ regulates GATA4 in cardiac myocytes. J Biol Chem 276: 28685-28597

Mutoh H, Naya FJ, Tsai MJ and Leiter AB (1998) The basic helix-loop-helix protein Beta2 interacts with p300 to coordinate differentiation of secretin-expressing enteroendocrine cells. Genes Dev 12: 820-830

Nordeen SK (1988) Luciferase reporter gene vectors for analysis of promoters and enhancers. BioTechniques 6: 454-457

O' Brien RM and Granner DK (1991) Regulation of gene expression by insulin. Biochem J 278: 609-619

O' Brien RM and Granner DK (1996) Regulation of gene expression by insulin. Physiological Reviews 76: 1109-1160

Park IK, Roach P, Bondor J, Fox SP and DePaoli-Roach AA (1994) Molecular mechanism of the synergistic phosphorylation of phosphatase inhibitor-2. Cloning, expression and site-directed mutagenesis of inhibitor-2. J Biol Chem 269: 944-954

Perissi V, Dasen JS, Kurokawa R, Wang Z, Korzus E, Rose DW, Glass CG, Rosenfeld MG (1999) Factor-specific modulation of CREB-binding protein acetyltransferase activity. Proc Natl Acad Sci USA 96: 3652-3657

Phiel CJ, Wilson CA, Lee VMY, Klein PS (2003) GSK-3 $\alpha$ regulates production of Alzheimer's disease amyloid- $\beta$ peptides. Nature 423: 435-439

Philippe J (1989) Glucagon gene transcription is negatively regulated by insulin in a hamster islet cell line. J Clin Invest 84: 672-677

Philippe J (1991) Insulin regulation of the glucagon gene is mediated by an insulinresponsive DNA element. Proc Natl Acad Sci USA 88: 7224-7227 
Philippe J, Drucker DJ, Knepel W, Jepeal L, Misulovin Z, Habener HF (1988) Alphacell-specific expression of the glucagon gene is conferred to the glucagon promoter element by the interactions of DNA-binding-proteins. Mol Cell Biol 8: 4877-4888

Pierreux CE, Urs B, De Meyts P, Rousseau GG and Lemaigre FP (1998) Inhibition by insulin of glucocorticoid-induced gene transcription: involvement of the ligand-binding domain of the glucocorticoid receptor and independence from the phosphatidylinositol 3kinase and mitogen-activated protein kinase pathways. Mol Endocrinol 12: 1343-1354

Pierreux CE, Rousseau GG and Lemaigre FP (1999) Insulin inhibition of glucocorticoidstimulated gene transcription: requirement for an insulin response element? Mol Cell Endocrinol 147: 1-5

Plyte SE, Hughes K, Nikolakaki E, Pulverer BJ, Woodgett JR (1992) Glycogen synthase kinase-3 : functions in oncogenesis and development. Biochim Biophys Acta 1114: 147-162

Polakis P (2000) Wnt signalling and cancer. Genes Dev 14: 1837-1851

Polakis P (2002) Casein kinase 1: A Wnt'er of disconnect. Curr Biol 12: 499-501

Primot A, Baratte B, Gompel M, Borgne A, Liabeuf S, Romette JL, Jho E, Constantini F and Meijer L (2000) Purification of GSK-3 by affinity chromatography on immobilized axin. Protein Expr Purif 20: 394-404

Pulverer BJ, Fisher C, Vousden K, Littlewood T, Evan G and Woodgett JR (1994) Sitespecific modulation of c-Myc cotransformation by residues phosphorylated in vivo. Oncogene 9: $59-70$

Qiu Y, Sharma A and Stein R (1998) p300 mediates transcriptional stimulation by the basic helix-loop-helix activators of the insulin gene. Mol Cell Biol 18: 2957- 2964

Rao A (1994) NF-ATp : a transcription factor required for the coordinate induction of several cytokine genes. Immunol Today 15: 274-281

Ring DB, Johnson KW, Henriksen EJ, Nuss JM, Goff D, Kinnick TR, Ma ST, Reeder JW, Samuels I, Slabiak T, Wagman AS, Hammond MEW and Harrison SD (2003) Selective glycogen synthase kinase 3 inhibitors potentiate insulin activation of glucose transport and utilization in vitro and in vivo. Diabetes 52: 588-595

Ritz-Laser B, Estreicher A, Klages N, Saule S and Philippe J (1999) Pax6 and cdx-2/3 interact to activate glucagon gene expression on the G1 control element. J Biol Chem 274: 4124-4132

Ross S, Erickson R, Hemati N and MacDougald OA (1999) Glycogen synthase kinase 3 is an insulin-regulated C/EBP $\alpha$ kinase. Mol \& Cell Biol 19: 8433-8441

Roymans D and Slegers H (2001) Phosphatidylinositol 3-kinases in tumor progression. Eur J Biochem 268: 487-498 
Rubinfeld B, Albert I, Porfiri E,Fiol C, Munemitsu S and Polakis P (1996) Binding of GSK3beta to the APC-beta-catenin complex and regulation of complex assembly. Science 272: $1023-1026$

Ryves WJ, Dajani R, Pearl L and Harwood AJ (2002) Glycogen synthase kinase-3 inhibition by lithium and beryllium suggests the presence of two magnesium binding sites. Biochem Biophys Res Commun 290: 967-972

Saltiel AR (1996) Diverse signalling pathways in the cellular actions of insulin. Am J Physiol Endocrinol Metab 270: E375-E385

Saltiel AR (2001a) New perspectives into the molecular pathogenesis and treatment of type 2 diabetes. Cell 104: 517-529

Saltiel AR and Kahn RC (2001b) Insulin signalling and the regulation of glucose and lipid metabolism. Nature 414: 799-806

Sambrook J, Fritsch EF and Maniatis T (1989) Molecular cloning. A laboratory manual. 2nd edition Cold Spring Harbor Laboratory

Sander M, Neubüser A, Kalamaras J, Ee HC, Martin GR, German MS (1997) Genetic analysis reveals that Pax6 is required for normal transcription of pancreatic hormone genes and islet development. Genes Dev 11: 1662-1673

Schinner S et al. manuscript in preparation

Schwaninger M, Lux G, Blume R, Oetjen E, Hidaka H and Knepel W (1993) Membrane depolarization and calcium influx induce glucagon gene transcription in pancreatic islet cells through the cyclic AMP-responsive element. J Biol Chem 268: 5168-5177

Seely BL, Staubs PA, Reichart DR, Berhanu P, Milarski KL, Saltiel AR, Kusari j, Olefsky JM (1996) Protein tyrosine phosphatase 1B interacts with the activated insulin receptor. Diabetes 45: 1379-1385

Shaw M, Cohen P and Alessi DR (1997) Further evidence that the inhibition of glycogen synthase kinase- $3 \beta$ by IGF-1 is mediated by PDK1/PKB-induced phosphorylation of Ser-9 and not by dephosphorylation of Tyr-216. FEBS Lett 416: 307-311

Shikama N, Lyon J, La Thangue NB (1997) The p300/CBP family: integrating signals with transcription factors and chromatin. Trends Cell Biol 7: 230-236

Slack JMW (1995) Developmental biology of the pancreas. Development 121: 1569-1580

Stümpel F, Scholtka B, Hunger A, Jungermann K (1998) Enteric glucagon 37 rather than pancreatic glucagon 29 stimulates glucose absorption in rat intestine. Gastroenterology 115: $1-10$

Takaki R, Ono J, Nakamura M, Yokogawa Y, Kumae S, Hiraoka T, Ymaguchl K, Hamaguchi $\mathbf{K}$ and Uchida $\mathbf{S}$ (1986) Isolation of glucagon-secreting cell lines by cloning insulinoma cells. In Vitro Cell Dev Biol 22: 120-126 
Tang ED, Nunez G, Barr FG, Guan KL (1999) Negative regulation of the forkhead transcription factor FKHR by Akt. J Biol Chem 274: 16741-16746

ter Haar E, Coll JT, Austen DA, Hsiao HM, Swenson L and Jain J (2001) Structure of GSK3beta reveals a primed phosphorylation mechanism. Nat Struct Biol 8: 593-596

Thompson MJ, Roe MW, Malik RK, Blackshear PJ (1994) Insulin and other growth factors induce binding of the ternary complex and a novel protein complex to the c-fos serum response element. J Biol Chem 269: 21127-21135

Toker A and Newton AC (2000) Cellular signalling : pivoting around PDK1. Cell 103: 185188

Unger RH, Orci L (1981) Glucagon and the A cell (first part). New Engl J Med 304: 15181524

Unger RH, Orci L (1981) Glucagon and the A cell (second part). New Engl J Med 304: $1575-1580$

Vanhaesebroeck B, Leevers SJ, Panayotou G, Waterfield MD (1997) Phosphoinositide 3kinases : a conserved family of signal transducers. Trends Biochem Sci 22: 267-272

van Noort M, Meeldijk J, van der Zee R, Destree O and Clevers H (2002) Wnt signalling controls the phosphorylation status of beta-catenin. J Biol Chem 277: 17901-17905

Wang D and Sul HS (1997) Upstream stimulatory factor binding to the E-box at -65 is required for insulin regulation of the fatty acid synthase promoter. J Biol Chem 272: 2636726374

Wang QM, Fiol CJ, DePaoli-Roach AA and Roach PJ (1994) Glycogen synthase kinase-3 beta is a dual specificity kinase differentially regulated by tyrosine and serine/threonine phosphorylation. J Biol Chem 269: 14566-14574

Welsh GI and Proud CG (1993) Glycogen synthase kinase-3 is rapidly inactivated in response to insulin and phosphorylates eukaryotic initiation factor eIF2B. Biochem J 294: 625-629

Weston CR and Davis RJ (2001) Signaling specificity - a complex affair. Science 292: 2439-2440

Williams RS and Harwood AJ (2000) Lithium therapy and signal transduction. Trends Pharmacol Sci 21: 61-64

Woodgett JR (1990) Molecular cloning and expression of glycogen synthase kinase-3/factor A. EMBO J 9: 2431-2438

Woodgett JR (2001) Judging a Protein by More than its Name: GSK-3. Science's STKE (100): RE12 
Yamauchi T, Kamon J, Waki H, Terauchi Y, Kubota N, Hara K, Mori Y et al. (2001) The fat-derived hormone adiponectin reverses insulin resistance associated with both lipoatrophy and obesity. Nat Med 7: 941-946

Yanagawa S, Matsuda Y, Lee JS, Matsubayashi H, Sese S, Kadowaki T and Ishimoto A (2002) Casein kinase I phosphorylates the armadillo protein and induces its degradation in Drosophila. EMBO J 21: 1733-1742

Yang C, Shapiro LH, Rivera M, Kumar A and Brindle PK (1998) A role for CREB binding protein and p300 transcriptional coactivators in Ets-1 transactivation functions. $\mathrm{Mol}$ Cell Biol 18: 2218-2229

Yeagley D, Agati JM and Quinn PG (1998) A tripartite array of transcription factor binding sites mediates cAMP induction of phosphoenolpyruvate carboxykinase gene transcription and its inhibition by insulin. $J$ Biol Chem 273: 18743-18750

Yost C, Torres M, Miller JR, Huang E, Kimelman D and Moon R (1996) The axisinducing activity, stability and subcellular distribution of beta-catenin is regulated in Xenopus embryos by glycogen synthase kinase 3. Genes Dev 10: 1443-1454

Zimmet P, Alberti KGMM and Shaw J (2001) Global and societal implication of the diabetes epidemic. Nature 414: 782-787 


\section{Acknowledgements}

I am grateful to Prof. W. Knepel for giving me the opportunity to work in his laboratory and for his excellent supervision.

I would like to thank Prof. R. Hardeland and Prof. T. Pieler for acting as referent and coreferent respectively.

I am also especially thankful to Prof. G. Burckhardt for his active support during all these years I was member of the GRK 335.

Many thanks to Dr. Elke Oetjen and Roland Blume for helpful discussions on various technical and theoretical aspects.

Last but not least, not to forget to acknowledge people from the laboratory that were always willing to help in any circumstances. Many thanks to Ulrike, Doris, Frau Hermann, Sabine, Payam and Ralf.

Finally, I would like to thank the students with whom I worked together all these years: Nashat, Ira, Marta and Julia. 


\section{Curriculum Vitae}

\section{Personal data}

Name:

Date of birth:

Place of birth:

Nationality:

\section{School education}

$1982-1988$

1988 - 1991

1991 - 1994

1995

\section{University education}

091995 - 11.1999

$03.1999-09.1999$

11.1999

09.2000

$09.2000-09.2003$
Nikolaos Dimopoulos

21.07.1976

Athens, Greece

Greek $5^{\text {th }}$ Primary School of Kallithea, Athens, Greece

$12^{\text {th }}$ Gymnasium of Kallithea, Athens, Greece

$3^{\text {rd }}$ Lyceum of Kallithea, Athens, Greece

Entry through the National Exams in the Department of Biology, University of Patras, Greece
University of Patras, Department of Biology, Greece

Max Planck Institute for Biophysical Chemistry, Department of Molecular and Developmental Biology, Goettingen, Germany

Diploma thesis (under the supervision of Prof. H.Jaeckle) Title: "Cloning and Characterization of Glutathione Peroxidase homologues in Drosophila melanogaster" Ptichio (B.Sc.) in Biology

Entry in the Postgraduate Programme of the GeorgAugust-University of Goettingen, Germany "Cellular, molecular and clinical Biology of internal organs" (GRK335, speaker Prof. G. Burckhardt)

Georg-August-University of Goettingen, Department of Molecular Pharmacology, Centre of Pharmacology and Toxicology, Germany

$\mathrm{PhD}$ thesis (under the supervision of Prof. W. Knepel) Title: "A role for glycogen synthase kinase 3 beta in the regulation of glucagon gene transcription by insulin" 